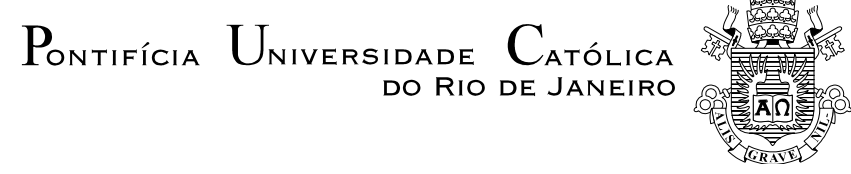

Keila Cabral Souto

A Constatação da Deficiência do(a)Filho(a)
e os Processos de (Re)Organização das
Famílias para o Cuidado

Dissertação de Mestrado

Dissertação apresentada ao Programa de PósGraduação em Serviço Social da PUC-Rio como requisito parcial para obtenção do título de Mestre em Serviço Social.

Orientador: Prof. Antonio Carlos de Oliveira 


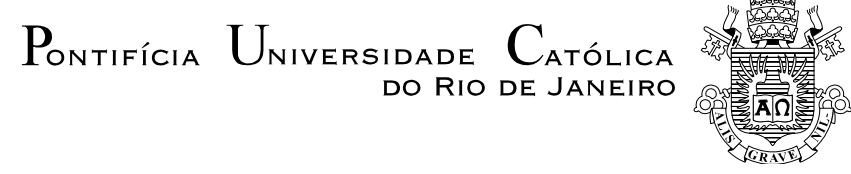

Keila Cabral Souto

\title{
A Constatação da Deficiência do(a)Filho(a) e os Processos de (Re)Organização das Famílias para o Cuidado
}

Dissertação apresentada como requisito parcial para obtenção do grau de Mestre pelo Programa de PósGraduação em Serviço Social do Departamento de Serviço Social do Centro de Ciências Sociais da PUCRio. Aprovada pela Comissão Examinadora abaixo assinada.

\author{
Prof. Antonio Carlos de Oliveira \\ Orientador \\ Departamento de Serviço Social - PUC-Rio \\ Profa. Sueli Bulhões da Silva \\ Departamento de Serviço Social - PUC-Rio \\ Profa. Nívia Valença Barros \\ UFF \\ Profa. Mônica Herz \\ Vice-Decana de Pós-Graduação do \\ Centro de Ciências Sociais - PUC-Rio
}

Rio de Janeiro, 22 de maio de 2013 
Todos os direitos reservados. É proibida a reprodução total ou parcial do trabalho sem a autorização da universidade, da autora e do orientador.

\section{Keila Cabral Souto}

Graduou-se em Serviço Social pela Universidade Federal do Rio de Janeiro (UFRJ) em 2002. No período da graduação, participou da pesquisa intitulada "O Estado da Arte sobre Paternidade", sob coordenação do Núcleo de Estudos e Saúde Reprodutiva da Escola de Serviço Social da UFRJ. Possui Pós-Graduação em Serviço Social Organizacional pela Universidade Veiga de Almeida em 2008. Atua profissionalmente como Assistente Social de um Plano de autogestão em saúde de uma Empresa brasileira de grande porte, desde 2006. Em 2009, integrou a equipe multidisciplinar de um programa de atenção a pessoas com deficiência, gerido por esse Plano.

Ficha Catalográfica

Souto, Keila Cabral

A constatação da deficiência do(a) filho(a) e os processos de (re)organização das famílias para o cuidado / Keila Cabral Souto ; orientador: Antonio Carlos de Oliveira. - 2013.

$141 \mathrm{f}$; $30 \mathrm{~cm}$

Dissertação (mestrado)-Pontifícia Universidade Católica do Rio de Janeiro, Departamento de Serviço Social, 2013.

Inclui bibliografia.

1. Serviço social - Teses. 2. Famílias. 3. Cuidado. 4. Deficiência. 5. Reorganização familiar. I. Oliveira, Antonio Carlos de. II. Pontifícia Universidade Católica do Rio de Janeiro. Departamento de Serviço Social. III. Título. 
Às Pessoas com Deficiência, pelas quais nutro grande respeito, admiração e gratidão. Respeito-as por terem sido protagonistas das lutas pela garantia dos seus direitos, hoje legalmente reconhecidos. Admiro-as diariamente, a cada história de superação de que tomo conhecimento. E lhes sou grata por terem dado ainda mais sentido à minha atividade profissional, incentivando-me à busca incessante pelo aprimoramento teórico e prático. 


\section{Agradecimentos}

A Deus por permitir-me senti-lo sempre presente e por influenciar e conduzir minha vida. Obrigada, Senhor, por possibilitar a concretização de mais esse sonho!

Aos meus pais, Ilza e Gerson, pelo amor e cuidado. Obrigada por apoiarem minhas decisões e por estarem sempre ao meu lado, ajudando a superar todos os desafios!

Ao Programa de Pós-Graduação em Serviço Social da PUC-RIO pela confiança em aceitar-me em seu quadro de mestrandos bolsistas e a CAPES por fomentar minha bolsa de estudos.

Ao Professor Antonio Carlos de Oliveira pelas preciosas orientações, que além de ajudarem a organizar meus pensamentos, possibilitaram-me maior tranquilidade e autoconfiança. Muito obrigada pela disponibilidade, pelo respeito a meu tempo de produção dos capítulos, pelas palavras motivadoras e por permitir que a relação orientador/orientado tenha ocorrido de maneira flexível e agradável!

À professora Sueli Bulhões Silva por ter me orientado nos passos iniciais do projeto de pesquisa e por ter sido minha supervisora no estágio em docência. Obrigada pelo carinhoso acolhimento!

À professora Fatima Cavalcante e, novamente, à professora Sueli Bulhões Silva pelas contribuições no exame de qualificação. 
À minha irmã Kelling e ao meu cunhado Marcelo, Doutores em Engenharia Nuclear, por serem meus exemplos de que a vida deve ser levada com simplicidade e simpatia. Obrigada por me mostrarem que mais importante que os títulos conquistados, é o usufruto da vida ao lado da família e amigos!

À Beatriz, minha amada sobrinha e afilhada, por presentear-me com sorrisos e gracinhas que, por vezes, fizeram minimizar a angústia sentida pelas dificuldades de produzir esta dissertação. Obrigada por, com seus poucos meses de idade, ter me ensinado que é muito fácil ser feliz!

Aos meus queridos amigos (Vivian Passos, Erika Ferreira, Priscila Menezes, Shirlei Pereira, Bruno Cabral, Juliana Ferreira, Angelica Duarte, Esttela Guimarães, Suelen Kfuri, Priscilla Caroline, Daniele Barcellos, Rafaela Braga, Carolina Leão, Monica Simões, Luciana Teixeira, Renato Marcolino, Cristiane Corrêa e Flaviana Couto) e ao meu primo Alex Souto pelas palavras de incentivo e por compreenderem os dias em que estive ausente, justificados pelas obrigações do mestrado.

Aos colegas de turma do mestrado, os quais muito admiro pela competência, por participarem das alegrias e dificuldades dessa caminhada. Em especial às queridas Roberta Duran e Rosane Nunes pelo privilégio de suas amizades.

Aos amigos do trabalho, que compartilham comigo as delícias e dores de trabalhar em um plano de autogestão em saúde de uma grande empresa. Obrigada pelas ricas discussões e parcerias que me incentivaram a buscar aprimoramento teórico. Em especial às queridas Luciana Garcia, Andreia Gonçalves, Simone Engelke e Daniele Barcellos. À Luciana pelas lições de serenidade e pela generosidade em dividir suas experiências. À Andreia por ensinar-me, na prática, o valor do trabalho interdisciplinar. À Simone pelos ricos conselhos e pelos votos sinceros. À Daniele por ter vibrado comigo ao saber da minha aprovação no mestrado e pelo apoio e torcida ao longo dessa caminhada.

À minha primeira Gerente, Maria Angela Madeira, por todo incentivo ao meu desenvolvimento profissional e acadêmico. Sua influência foi fundamental para 
minha decisão de realizar o mestrado. Obrigada por tudo que fez por mim: atenção, treinamentos, confiança, críticas construtivas, reconhecimento e recompensa. Você será sempre minha referência!

À minha atual Gerente Jeane Greef e ao meu Supervisor Paulo Filho por serem atenciosos às minhas expectativas e compreensivos com relação aos compromissos impostos pelo mestrado. Obrigada por contribuírem para meu crescimento teórico-prático!

Aos pais e mães entrevistados, pela generosidade em participar desta pesquisa. Obrigada por confiarem a mim suas admiráveis histórias de vida familiar! 


\section{Resumo}

Souto, Keila Cabral; Oliveira, Antonio Carlos. A Constatação da Deficiência do(a) Filho(a) e os Processos de (Re)Organização das Famílias para o Cuidado. Rio de Janeiro, 2013. 141p. Dissertação de Mestrado - Departamento de Serviço Social, Pontifícia Universidade Católica do Rio de Janeiro.

Esta pesquisa tem como objetivo conhecer os processos de (re)organização das famílias, a partir da constatação da deficiência do(a) filho(a), em particular no que se refere ao cuidado da prole. Procedeu-se a uma pesquisa qualitativa, utilizando-se a técnica de entrevistas narrativas para a coleta de dados. Foram entrevistados dois pais e duas mães de pessoas com deficiência, vinculados a uma empresa brasileira de grande porte e que integram as classes média e de elite da população brasileira, cujos filhos apresentam múltiplos comprometimentos e tiveram sua deficiência constatada há pelo menos cinco anos. Os dados coletados na pesquisa de campo foram discutidos a partir da análise de conteúdo, em sua modalidade temática, e apontam para mudanças e permanências nas relações de gênero no que se refere ao cuidado dos filhos, prevalecendo seu exercício pela mãe e outras mulheres, porém com participação dos pais. Também demonstram que os processos de (re)organização das famílias para o cuidado foram facilitados pelas redes de suporte social, dificultados pela discriminação dirigida às pessoas com deficiência e demarcados, sobretudo, pela inserção dos filhos em apoios continuados, em grande parte possibilitada pela colocação profissional e pelo poder aquisitivo dos pais e mães.

\section{Palavras-chave}

Famílias; Cuidado; Deficiência; Reorganização Familiar. 


\section{Abstract}

Souto, Keila Cabral; Oliveira, Antonio Carlos (Advisor). The Finding of Children's Disability and The Reorganization of the Family for the Necessary Care. Rio de Janeiro, 2013. 141p. MSc. Dissertation Departamento de Serviço Social, Pontifícia Universidade Católica do Rio de Janeiro.

This research aims to know about the families' reorganization processes from the moment of the finding of a child's disability, especially in relation to the children's care. A qualitative research was done using the technique of narrative interviews for the data collection. Two fathers and two mothers of disabled children were interviewed. They belong to classes A and B and are associates of a big Brazilian company. Their children present multiple disabilities which had been discovered at least five years ago. The data collected in the field research were discussed based on the analysis of the content in its thematic modality. They indicate changes and continuities in gender relations in reference to the care of the child with the prevalence of the mother and other women for that care but also with the participation of the father. They also show that, on one hand, the families' reorganization processes for the necessary care were made easier by the help of social support networks. On the other hand, the same processes were hampered by the discrimination against disabled people and significantly affected by the inclusion of the children in continued support programs, which was only possible due to the parent's social position and financial conditions.

\section{Keywords}

Families; Care; Disability; Family Reorganization. 


\section{Sumário}

Introdução

14

1. Famílias em Questão: Contextos Influenciadores 20 dos Comportamentos Familiares

1.1. Relações de Gênero e Famílias 21

1.1.1. Bases Fundadoras das Relações de Gênero 22

1.1.2. Relações de Gênero na Contemporaneidade 25

1.1.3. Famílias Brasileiras Contemporâneas e a 30 Influência Ideológica das Relações de Gênero Brasileiras

1.3. Funcionamentos de Famílias em Situações de 39 Mudança

2. O Cuidado em Foco: Principais Aspectos da Atividade de Cuidar

2.1. Dimensões Macro e Micro da Atividade de Cuidar 46

2.2. Aspectos Formal e Informal da Atividade de Cuidar 49

2.3. Cuidados de Pessoas com Deficiência e 56 suas Implicações para as Famílias

2.3.1. Identificação do Cuidador de Pessoas com Deficiência no Âmbito Familiar

2.3.2. A Constatação da Deficiência do(a) Filho(a) 58 e Seus Significados para as Famílias

2.3.3. Processos de (Re)organização nas Dinâmicas

Familiares e as Implicações para as Famílias

3. Constatação da Deficiência do(a) Filho(a) e os Processos de (Re)Organização de Famílias Vinculadas a uma Empresa Brasileira de Grande Porte 
3.1. Percurso Metodológico: Seleção dos Sujeitos, Acesso ao Campo, Realização da Pesquisa e Análise dos Dados

3.2. Caracterização das Famílias Sujeitos da Pesquisa 71

3.3. Do Nascimento à Constatação da Deficiência 74 do(a) Filho(a)

3.4. Significados da Constatação da Deficiência do(a) 82 Filho(a) para as Famílias Sujeitos da Pesquisa

3.5. Processos de (Re)Organização das Famílias e o 85 Cuidado do(a) Filho(a) com Deficiência

3.5.1. Identificação do Cuidador de Pessoas com Deficiência no Âmbito das Famílias Sujeitos da Pesquisa

3.5.2. Processos de (Re)Organização das Famílias Sujeitos da Pesquisa, a Partir da Constatação da Deficiência do(a) Filho(a)

3.5.3. Contextos Facilitadores e Dificultadores do Cuidado do(a) Filho(a) com Deficiência

3.6. Implicações da Deficiência do(a) Filho(a) para os Integrantes das Famílias Sujeitos da Pesquisa

4. Considerações Finais

5. Referências Bibliográficas

6. Apêndice

138

7. Anexo 


\section{Lista de Siglas e Abreviaturas}

BPC Benefício de Prestação Continuada

CAPS Centros de Atenção Psicossocial

DF Deficiência Física

DSA Deficiência Sensorial Auditiva

DI Deficiência Intelectual

DM Deficiência Múltipla

DSV Deficiência Sensorial Visual

EEG Eletroencefalograma

FGV Fundação Getúlio Vargas

HIV/AIDS Vírus da Imunodeficiência Humana/ Acquired Immune Deficiency

OMS Organização Mundial da Saúde

PAM Posto de Atendimento Médico

PUC-Rio Pontifícia Universidade Católica do Rio de Janeiro

TCC Trabalho de Conclusão de Curso

TDAH Transtornos de Déficit de Atenção e Hiperatividade

TGD Transtornos Globais de Desenvolvimento

UFF Universidade Federal Fluminense

UFRJ Universidade Federal do Rio de Janeiro

UTI Unidade de Terapia Intensiva 
As tarefas que nos propomos devem conter exigências que pareçam ir além de nossas forças. Caso contrário, não descobrimos nosso poder, nem conhecemos nossas energias escondidas e assim deixamos de crescer.

Leonardo Boff 


\section{Introdução}

A literatura propõe que a constatação da deficiência de um filho gera vicissitudes nas dinâmicas familiares ${ }^{1}$ (Silva \& Dessen, 2001; Petean \& Neto, 1998; Sprovieri \& Junior, 2001; Bastos \& Deslandes, 2008). Essa constatação não se configura, necessariamente, no primeiro acontecimento que incita organização nas famílias, visto que, conforme postulado por Minuchin (1982), mesmo antes do nascimento dos filhos, o sistema familiar passa por mudanças que implicam em adaptação e acomodação. E é embasado nesse entendimento que estamos optando pelo prefixo 're' antes do termo 'organização familiar', quando nos referimos às mudanças nas famílias a partir da constatação da deficiência do(a) filho(a).

O período do diagnóstico da deficiência é considerado o mais difícil para as famílias (Silvia \& Dessen, 2001), pois o sofrimento de pais e mães ao receber a notícia é agudo e está vinculado ao sentimento de luto pela perda do filho esperado (Petean \& Neto, 1998; Sprovieri \& Junior, 2001).

Passado o período inicial da constatação da deficiência, as famílias buscam (re)organizações internas, criando artifícios para adaptarem-se a estes filhos e às suas necessidades de cuidado (Silva \& Dessen, 2001; Bastos \& Deslandes, 2008). Essas (re)organizações não ocorrem de forma idêntica entre as famílias.

Certos processos de (re)organização nas dinâmicas familiares podem não ser acolhedores do(a) filho(a); em geral pela negação da sua deficiência. Nesses casos, as famílias tendem a não empreenderem ações contributivas para o desenvolvimento desse(a) filho(a), na medida em que ficam paralisadas ou buscam alcançar resultados impossíveis, tal como a reparação da deficiência (Cavalcante, 2007; Góes, 2004). Tais dinâmicas familiares, além de tenderem a prejudicar a evolução global do(a) filho(a) deficiente, também podem gerar frustrações para as famílias, interferindo na saúde de seus integrantes (Cavalcante, 2007; Sprovieri \& Júnior, 2001). Ações que também podem acarretar prejuízos

\footnotetext{
${ }^{1}$ A terminologia dinâmica familiar é aqui compreendida pelas maneiras como os membros das famílias ajustam-se em termos de composição, divisão de tarefas no lar e de tempo dedicado a essas tarefas. Os estudiosos da temática deficiência evidenciam a categoria dinâmica familiar ao retratarem as mudanças que ocorrem na organização das famílias a partir da constatação da deficiência de um dos seus integrantes (PETEAN \& MURATA, 2000; SPROVIERI \& JUNIOR, 2001).
} 
para o desenvolvimento das potencialidades da pessoa com deficiência são os cuidados em excesso ou em carência. Faz-se necessário um equilíbrio na atividade de cuidar (Boff, 2011).

Processos de (re)organizações nas dinâmicas familiares que tendem a possibilitar a construção de um ambiente favorável para o desenvolvimento psíquico e social do(a) filho(a) com deficiência e para o bem-estar dos demais integrantes das famílias são aqueles que vão ao encontro de diferentes e necessárias formas de ajuda na sociedade, a partir da superação da fantasia do(a) filho(a) idealizado e aceitação dos limites e possibilidades da pessoa com deficiência (Cavalcante, 2007; Sprovieri \& Júnior, 2001).

São tais processos de (re)organização das famílias, a partir da constatação da deficiência do(a) filho(a), em particular no que se refere ao cuidado da prole, que consiste o objeto da nossa investigação. A partir dos estudos bibliográficos e da pesquisa de campo foram coletados dados que atendessem, também, aos seguintes objetivos específicos: identificar os contextos que favorecem e dificultam o cuidado do(a) filho(a) com deficiência, e conhecer as implicações da deficiência do(a) filho(a) para os integrantes das famílias. Considerando que tais implicações podem ser inúmeras e, portanto, talvez impossíveis de serem analisadas no limite temporal de uma dissertação de mestrado, optamos pelo recorte $^{2}$ naquelas relacionadas ao cuidado do(a) filho(a) com deficiência.

A motivação pelo estudo das categorias analíticas 'Famílias', 'Cuidado' e 'Deficiência' derivou das proposições da literatura específica - acima sintetizadas -, da sua relevância acadêmica e do nosso percurso acadêmico e profissional.

Avaliamos que a pesquisa tem relevância acadêmica por apresentar temáticas pouco exploradas pelo campo de investigação do Serviço Social brasileiro contemporâneo. Nos levantamentos bibliográficos sobre 'deficiência e família' e 'cuidado'3 foram localizadas publicações oriundas das mais diversas áreas da saúde, tais como: Psicologia, Medicina, Enfermagem, Fisioterapia, Terapia Ocupacional. Entretanto, não encontramos obras científicas nacionais publicadas pela categoria de Assistentes Sociais.

\footnotetext{
${ }^{2}$ De acordo com Minayo, "Nenhuma teoria, por mais bem elaborada que seja, dá conta de explicar todos os fenômenos e processos. O investigador separa, recorta determinados aspectos significativos da realidade para trabalhá-los (...).” (2003, p.18).

${ }^{3}$ Pesquisamos produções científicas brasileiras (artigos, dissertações e teses) publicadas no período compreendido entre o ano 2000 e 2012.
} 
No que se refere ao nosso percurso acadêmico, citamos a graduação no curso de Serviço Social da UFRJ (2002-2005), quando tivemos a oportunidade de compor a equipe de estudantes colaboradores do Núcleo de Saúde Reprodutiva e Trabalhos Femininos da Escola de Serviço Social daquela Universidade. Integramos o grupo que pesquisava acerca do Estado da Arte sobre a Paternidade e, a partir desta pesquisa, tivemos contato com a discussão acadêmica sobre relações de gênero, paternidade e divisão sexual do trabalho (Heilborn, 1999; Nolasco, 1993; Saraiva, 1998).

O despertar do interesse acerca dos temas supracitados contribuiu para tomarmos a decisão de estagiar na área de saúde reprodutiva. O estágio foi realizado em um Posto de Atendimento Médico (PAM) da Zona Sul do Rio de Janeiro. Neste PAM, a equipe de Serviço Social conduzia o Programa de Planejamento Familiar e promovia discussões sobre saúde reprodutiva nas salas de espera dos consultórios médicos. No estágio, pudemos comprovar, na prática, hipóteses suscitadas no Núcleo de Pesquisa; tais como: eram primordialmente as mulheres que buscavam a rede básica de atenção à saúde ${ }^{4}$; e também eram elas que participavam do Programa de Planejamento Familiar, o que corrobora a permanência da concepção, socialmente arraigada, de que muito do que se refere ao cuidar da família - incluindo o cuidado da saúde reprodutiva e a prevenção da gravidez não desejada - deverá ser preocupação e tarefa feminina (Giffin \& Cavalcanti, 2012). Sendo assim, o PAM parecia caracterizar-se como o lócus privilegiado das mulheres, que também buscavam o Posto para consultas ginecológicas ou para levarem os filhos a consultas com pediatras. Pelo que observamos, a presença dos homens era escassa, e se dava, sobretudo, num caráter imediatista: quando entravam no Posto para pedir preservativos. Nesses casos, em geral, eles eram encaminhados à equipe de Serviço Social, que procurava sensibilizá-los a participarem do Planejamento Familiar. Raros eram os casos em que havia anuências.

\footnotetext{
${ }^{4}$ Trata-se do primeiro nível de atenção à saúde, segundo o modelo adotado pelo SUS. É, preferencialmente, a "porta de entrada" do sistema de saúde. A população tem acesso a especialidades básicas, que são: clínica médica (clínica geral), pediatria, obstetrícia e ginecologia. Estudos demonstram que a atenção básica é capaz de resolver cerca de $80 \%$ das necessidades e problemas de saúde (MINISTÉRIO DA SAÚDE, 2012).
} 
Em síntese, no estágio verificamos que o cuidado com a saúde reprodutiva, a prevenção de doenças crônicas e o cuidado com a saúde dos filhos pareciam ser tarefas em que os homens pouco se envolviam, deixando-as a cargo das mulheres.

A experiência de estágio e os estudos e debates no Núcleo de pesquisa incentivou-nos a desenvolver o Trabalho de Conclusão de Curso (TCC) a respeito da relação do homem no cuidado familiar, em especial no que diz respeito aos filhos. O título do TCC foi "A Presença da Paternidade no Processo de Formação dos Filhos" (Souto, 2005), e o seu objetivo foi identificar se o cuidado e a relação pedagógica estabelecida no lar eram realizados com a participação do pai. Os resultados indicaram que, nos grupos estudados, os papéis exercidos nos contextos de famílias de baixa e média rendas caracterizavam-se pela reprodução da rígida divisão dos papéis de gênero ${ }^{5}$ : a mãe era a principal responsável pela organização do lar, cuidado e educação dos filhos; o pai era o provedor da casa e da família. Os pais/homens da classe média eram considerados menos rígidos com a família e menos distantes dos filhos, quando comparados aos pais/homens da classe empobrecida. Entretanto, quando o casal separava-se - o que se verificava com maior frequência nas famílias de classe média - os pais deixavam de participar da vida dos filhos e as mães assumiam as responsabilidades pelo cuidado, educação e provisão do lar. 'Cuidado' e 'Família' foram, portanto, categorias que despertaram nosso interesse investigativo desde a graduação.

Quanto ao nosso percurso profissional, que propiciou a ampliação do interesse pelo tema desta pesquisa, destacamos o ingresso no mercado de trabalho, no ano de 2006, quando integramos o quadro de Assistentes Sociais da operadora de autogestão em saúde de uma empresa brasileira de grande porte. Foi nessa área de atuação - mais especificamente a partir do ano de 2009 - que tivemos contato profissional com famílias de pessoas com deficiências, emergindo inquietações a respeito de suas histórias de vida.

A operadora de saúde é gerida e patrocinada pela companhia e sua finalidade é prestar assistência aos seus empregados, aposentados, pensionistas e dependentes, por meio de atividades médicas e hospitalares. Tais atividades são

\footnotetext{
${ }^{5}$ Divisão de papéis de gênero, também nomeada de divisão sexual do trabalho, pode ser definida como "uma diferenciação entre papéis femininos e masculinos que encontra na família sua manifestação privilegiada." (DURHAM, 1983, p. 18).
} 
organizadas em diversos programas, dentre os quais está o programa de assistência a pessoas com deficiência.

O programa é desenvolvido com o objetivo de disponibilizar recursos para a prestação de assistência especializada em habilitação, reabilitação e educação para pessoas com deficiências ou transtornos. São assistidos por esse programa, os filhos de empregados, de aposentados e de pensionistas da empresa que apresentam ao menos uma das deficiências ou transtornos descritos a seguir: Deficiência Física (DF), Deficiência Sensorial Visual (DSV), Deficiência Sensorial Auditiva (DSA), Deficiência Intelectual (DI), Deficiência Múltipla (DM), Transtornos Globais de Desenvolvimento (TGD) e Transtornos de Déficit de Atenção e Hiperatividade (TDAH).

Foi, portanto, por meio da atividade profissional que despertamos o interesse investigativo pela categoria 'Deficiência' e a integramos às temáticas 'Família' e 'Cuidado', que já vinham compondo nossos objetos de estudo em projetos anteriores.

Considera-se deficiência, tomando por referência o marco legal brasileiro, “toda perda ou anormalidade de uma estrutura ou função psicológica, fisiológica ou anatômica que gere incapacidade para o desempenho das atividades, dentro do padrão considerado normal para o ser humano.” (Brasil, 1999).

Cada deficiência tem as suas características e gera na pessoa limitações em algo que se considera como habilidades básicas para a vida social, tais como: mobilidade, uso dos sentidos, comunicação, interação social e cognição (Diniz et al., 2007). E são por essas características que as pessoas com deficiência tendem a demandar cuidados cotidianos por período prolongado, o que requer (re)organizações nas dinâmicas familiares (Silva \& Dessen, 2001; Bastos \& Deslandes, 2008). Buscamos conhecer tais processos de (re)organização das famílias, em relação ao cuidado dos filhos, por meio de pesquisa qualitativa e utilização da técnica de entrevista narrativa. A pesquisa de campo foi realizada com dois pais e duas mães de pessoas com deficiência, inscritas no programa de assistência a pessoas com deficiência da empresa brasileira supracitada.

As categorias 'Cuidado' e 'Família' estão conceituadas nos capítulos teóricos desta dissertação. O primeiro capítulo, que aborda, primordialmente, sobre 'Famílias', identifica contextos influenciadores dos comportamentos familiares, que podem ter reflexos nos seus processos de (re)organização. O 
segundo capítulo, que discute sobre 'Cuidado', abrange os cuidados profissional e familiar, e apresenta estudo bibliográfico sobre cuidado de pessoas em geral, culminando no específico cuidado de pessoas com deficiência. O capítulo três apresenta análise dos dados coletados nas entrevistas com famílias de pessoas com deficiência. São analisados os processos de (re)organização das famílias, sujeitos da pesquisa, a partir da constatação da deficiência dos seus filhos, tendo como norte as narrativas dos entrevistados. Neste capítulo, também são analisados os contextos favorecedores e dificultadores do cuidado, bem como se os dados coletados corroboram a literatura corrente quanto às implicações da deficiência do(a) filho(a) para os integrantes das famílias pesquisadas.

Esta pesquisa não tem a pretensão de esgotar ${ }^{6}$ conhecimentos a respeito de processos de (re)organização familiares, senão fornecer elementos de contribuição aos estudos, até então produzidos, acerca dos cuidados de pessoas com deficiência por suas famílias.

\footnotetext{
${ }^{6}$ Segundo Minayo (2003), (...) a Ciência é uma atividade de aproximação sucessiva da realidade que nunca se esgota, fazendo uma combinação particular entre teoria e dados (p.17).
} 


\section{Famílias em Questão: Contextos Influenciadores dos Comportamentos Familiares}

Neste primeiro capítulo, buscaremos enveredar pelo campo da instituição Família, a fim de que tenhamos elementos para análise do nosso objeto de estudo. Partimos do entendimento de que os comportamentos das famílias ${ }^{7}$ são influenciados por contextos ideológicos (Bruschini, 1993), políticos (Mioto, 2006) e psicológicos (Minuchin, 1982). Dessa forma, para que possamos conhecer como as famílias (re)organizam-se em situações de mudanças, tais como a constatação da deficiência do(a) filho(a), buscaremos estudar a influência e os reflexos desses contextos nas dinâmicas familiares.

Destacamos as influências ideológicas das relações de gênero que, transmitidas socialmente, ao longo de gerações, constituem importantes referências para a compreensão da diferença de papéis e comportamentos assumidos por homens e mulheres nas famílias. Os níveis de escolaridade dos integrantes das famílias e os padrões de consumo familiar também podem ser importantes influenciadores de seus comportamentos (Sorj, 2003; Arriagada, 2006; Giffin, 2002; Araujo \& Scalon, 2003); esses aspectos parecem demonstrar que a efetividade ou a escassez das políticas sociais tem reflexos na vida das famílias, incidindo sobre as condições de suas sustentabilidades e organizações internas. Lançando mão de referências (Minuchin, 1982; Szymansky, 2005; Bronfenbrenner, 1996) que abordam acerca do funcionamento das famílias, defendemos que os comportamentos familiares são influenciados por condições intrafamiliares, tais como os processos psíquicos de cada membro da família, e por sistemas extrafamiliares diversos, que vão desde as instituições sociais até as ideologias e valores que permeiam a sociedade.

\footnotetext{
${ }^{7}$ A utilização do plural na grafia da palavra 'famílias' demarca o reconhecimento da existência de uma diversidade de arranjos; contrapondo a recorrente tendência de idealizarmos uma única imagem de família (OLIVEIRA, 2011).
} 


\section{1 Relações de Gênero e Famílias}

Buscar reconhecer o caráter histórico da instituição família e da construção social das relações de gênero ${ }^{8}$ parece-nos relevante para possibilitar um olhar desnaturalizante do que podemos ver hoje.

Morgado (2001) demonstra-se partidária da concepção de família como instituição que se modifica em consonância com as transformações históricas e que adquire particularidades em diferentes sociedades. A autora resgata Bruschini (1993) para propor a dissolução da aparência de naturalidade das organizações familiares, percebendo-a como criação humana mutável. Também nessa linha de pensamento, Oliveira (2011) registra que a sociedade percorreu um caminho histórico para chegar às bases da estrutura de família que predomina nos dias de hoje. Segundo o autor, houve um período inicial em que o casamento endogâmico era permitido, passando para um segundo período caracterizado por restrições a esse tipo de união - em princípio por interesses econômicos - até chegar à estrutura de família monogâmica patriarcal, cuja prevalência da dominação masculina sobre o gênero feminino ainda serve de base para a nossa civilização.

O patriarcalismo - caracterizado pela identificação do masculino como referência social e pela autoridade do homem sobre a mulher e filhos no âmbito familiar - é uma das estruturas sobre as quais se assentam as sociedades contemporâneas (Saraiva, 1998; Castells, 2000). E é por essa atual e persistente influência da estrutura patriarcal nos comportamentos familiares, que justificamos a necessidade de dar-lhe destaque, abordando sua contextualização histórica.

\footnotetext{
${ }^{8}$ De acordo com Heilborn (1999), o conceito de gênero foi criado para distinguir a dimensão biológica da dimensão social, portanto, gênero refere-se às diferenças entre homens e mulheres, que não são determinadas pela natureza, mas sim pela cultura. Gênero é um produto social transmitido ao longo das gerações.
} 


\subsection{1 \\ Bases Fundadoras das Relações de Gênero}

O período patriarcal foi o marco inicial da supremacia do homem sobre a mulher. Nessa época feudal, o poder político absolutista do rei foi transferido ao patriarca nas famílias; dessa forma, o pai deteve poder ilimitado sobre a família, assim como o monarca detinha poder sobre toda a nação. Corroborando esta afirmação, Saraiva descreve: "Tanto o poder paterno era o poder monárquico, quanto vice-versa. O pai governava segundo sua vontade (uma vontade com força absoluta, ilimitada e arbitrária).” (Saraiva, 1998, p. 48). O poder do rei era associado ao poder de Deus; desta forma, como no espaço público havia uma associação entre Deus e o monarca, no âmbito privado da família houve um paralelo entre o poder de Deus sobre todos e o poder do pai sobre a família.

O patriarcado estabeleceu o masculino como referência e o feminino como sem valor. Para Saraiva, "o patriarcado é a exaltação dos valores masculinos tornados naturais e sustentados num princípio que se propunha inabalável, o do Pai” (1998, p. 45). Ainda segundo a mesma fonte, nesse período, as mulheres não foram valorizadas nem mesmo na qualidade de mães, pois os homens foram considerados os únicos responsáveis pela procriação dos filhos. Perceberam-se as mulheres como recipientes vazios a serem preenchidos pelos homens. Carregar a criança no ventre tornou-se o único papel considerado feminino, sem qualquer participação da mulher na concepção. Essa extrema valorização da paternidade, associada ao advento das guerras, explica a supremacia masculina na estrutura patriarcal.

No que se refere às guerras, o início da dominação de determinados povos sobre os outros e a luta pela posse de terras fizeram com que os homens fossem considerados ideais para responder às exigências da época e, portanto, mais valorizados que as mulheres na sociedade. Ideologicamente, criaram-se valores compatíveis com as necessidades daquele período: honra, soberania, poder e dominação. Tais valores passaram a definir a masculinidade, formando-se, portanto, a verdadeira identidade masculina - guerreiro, soberano e dominador (Saraiva, 1998) -, cujo modelo todos os homens deveriam seguir. 
A subsunção da família à vontade do patriarca representou para os filhos a impossibilidade de discordar da governança paterna acerca de suas vidas, de seus bens e casamentos. Os matrimônios eram arranjados pelos pais dos noivos, com objetivo maior de atender aos interesses econômicos. Não existia, portanto, o ideário amoroso de família, uma vez que essa instituição não era constituída a partir da afetividade existente entre o casal. Neste contexto, a representação da família não era como a que existe nos dias atuais: uma instituição que dá base para a vida e que garante segurança material e psicológica. De acordo com Ariès (1978), tratava-se de uma instituição cujo objetivo voltava-se para atender, primordialmente, aos interesses patrimoniais e de agregação, não existindo como um sentimento ou valor.

O sentimento de família só foi possível, segundo Saraiva (1998), com o aparecimento da ideia de amor romântico e do sentimento de infância. Ambos emergiram no bojo da modernidade, quando se passou a valorizar a união pelo amor e a perceber as crianças como seres que necessitavam de cuidados especiais; o que tornou a afetividade entre pais e filhos culturalmente maior. De acordo com Oliveira (2011), nesse período moderno, marcado pelo advento da família burguesa, também emergiu a noção de privacidade familiar. A partir de então, a responsabilidade pelo cuidado das crianças foi atribuída às mães, que lhes deveriam suprir as necessidades materiais e afetivas.

A sociedade moderna trouxe como herança da sociedade patriarcal a representação dos homens como superiores às mulheres, porém de maneira ressignificada. Com o advento da industrialização e a consequente valorização do trabalho remunerado, a imagem do guerreiro foi associada às características essenciais à reprodução do modo de produção capitalista emergente: racionalidade e capacidade de trabalhar. Assim, o homem moderno perdeu o papel político que possuía na sociedade patriarcal, mas assumiu o papel social de trabalhador. E a identidade do homem trabalhador tornou-se a identidade verdadeiramente masculina (Saraiva, 1998), valorizando-o como provedor e permitindo que mantivesse o domínio sobre a família.

Segundo Bruschini (1993), com as transformações geradas pela industrialização, acirrou-se a divisão de duas esferas distintas na sociedade: de um lado a unidade doméstica, de outro a unidade de produção. Essa fragmentação correspondeu a uma divisão sexual do trabalho mais rígida do que a que 
predominava anteriormente: "à mulher coube principalmente a divisão de tarefas relativas à reprodução da força de trabalho na esfera privada do lar e sem remuneração, enquanto ao homem coube o trabalho produtivo extralar, pelo qual passou a receber remuneração.” (Bruschini, 1993, p. 65).

O homem foi fixado no mundo do trabalho - o mundo da razão - e afastado de tudo que dizia respeito à emoção, incluindo expressões de sentimentos como afeto e amor. Essas habilidades foram atribuídas às mulheres, que percebidas como sensíveis e afetivas, passaram a ser consideradas ideais para assumirem responsabilidades associadas ao cuidado da família e educação dos filhos. A esse respeito, Saraiva descreve que:

O poder da mãe é exaltado enquanto pureza, instinto e capacidade ilimitada para cuidar e amar os filhos. A sociedade industrial, ao afastar pai e filho, coloca a mãe como responsável pela educação e instrução, pois a função de nutriz é desdobrada e associada à de formação (1998, p. 72).

A fixa divisão sexual do trabalho, distinguindo os papéis entre homem/provedor e mulher/cuidadora ${ }^{9}$, constituiu-se na principal característica do modelo de família nuclear burguesa (Morgado, 2001). A ideologia encarregou-se de transformar esta rígida divisão sexual do trabalho em uma divisão natural, como se fosse própria da biologia de cada sexo (Bruschini, 1993) ${ }^{10}$. E, embora esse modelo tivesse sua base de sustentação na burguesia, o poder ideológico fez com que, gradualmente, tais ideias fossem servindo como padrão de comportamento familiar para as classes trabalhadoras (Quintaneiro, 1995).

A literatura (Saraiva, 1998; Quintaneiro, 1995) considera que a modernidade representou, ao mesmo tempo, um avanço e um retrocesso nas

\footnotetext{
${ }^{9}$ Carvalho et al. (2008) sinalizam que foram as mulheres da classe média e alta que estiveram alijadas do trabalho produtivo na sociedade moderna, ficando confinadas no lar. Já as mulheres da classe proletária participaram do mercado de trabalho no período industrial. A distinção entre homens e mulheres das classes trabalhadoras ficou por conta dos salários, sempre mais baixos para elas quando comparados aos deles. Entretanto, as ideias do modelo de família nuclear também influenciaram o comportamento e pensamento dos operários, ainda que sua plena realização não fosse possível.

${ }^{10}$ Uma das razões do cuidado ter se configurado como uma atribuição feminina foi a tendência cultural de naturalização da maternidade. Segundo Ridenti (1998), a maternidade, pela ligação com o corpo, é um elemento muito forte em nossa cultura, determinando que cuidar seja uma atribuição exclusiva do gênero feminino. "As responsabilidades parentais são, pois, definidas considerando como principal referência a mãe, a partir do princípio biológico de que é no corpo dela que o bebê é concebido.” (RIDENTI, 1998, p. 10).
} 
relações de gênero. Um avanço porque, quando comparado ao período feudal, concedeu poder às mulheres. O poder se deve ao fato de que ser 'boa' esposa e dona de casa tornou-se um dever quase tão fundamental quanto o dos homens, que era o de produzir riquezas. Assim, os cuidados com a família passaram a ser assumidos como uma vocação e o trabalho doméstico, como uma profissão (Quintaneiro, 1995). Para que as mulheres pudessem assumir essas responsabilidades, foram-lhes conferidas qualidades altruístas: "devoção aos outros, fortaleza moral, afetividade, delicadeza, sensibilidade." (Quintaneiro, 1995, p. 46). Dessa forma, “ao irem se tornando 'especialistas', seja pela maternidade ou pelo domínio nas questões da intimidade, as mulheres foram ocupando postos que, sem dúvida, também o são de poder.” (Saraiva, 1998, p. 64). Entretanto, a modernidade também representou um retrocesso porque confinou as mulheres no espaço privado e, ao considerá-lo como de menor valor que o espaço masculino (público), ressignificou a ideologia de superioridade dos homens.

Com relação especificamente ao Brasil, esse modelo nuclear burguês estabeleceu-se, sobretudo, na sociedade urbana, prevalecendo a figura masculina como referência de autoridade. Segundo Morgado (2001), a década de 1930 pode ser tomada como representativa para a centralidade da família no país, pois foi valorizada pela possibilidade de assumir função socializadora dos valores adequados ao processo de modernização, que se desejava implantar. Ainda segundo a autora, a concepção de lar como 'lugar feminino' por excelência se radicalizou nesse período e às mulheres foi atribuído o papel de educadoras. Já os homens, na família modelo daquela época, detiveram autoridade sobre as mulheres e assumiram a responsabilidade pelo sustento do lar.

A literatura (Morgado, 2001; Saraiva, 1998; Bruschini, 1993) esclarece que o modelo de família nuclear, com sua rígida divisão de papéis de gênero, prevalece como dominante na sociedade contemporânea, principalmente no que se refere ao campo ideológico. Entretanto, como demonstrado, não se trata de um modelo universal e natural, mas sim de um fenômeno social e historicamente construído e, portanto, passível de ser modificado.

O caráter histórico da família possibilita-nos desmistificar a percepção, atualmente existente, de que essa instituição é a base do amor e o local da felicidade (Stamm \& Mioto, 2003). Tal visão pode influenciar profissionais que 
atuam com famílias e pesquisadores que analisam os comportamentos familiares, levando-os a naturalizarem as relações a partir do modelo socialmente construído do que deve ser uma família e como devem comportar-se os pais e as mães. No intuito de não incorrermos nesse equívoco na pesquisa sobre os processos de (re)organização das famílias, a partir da constatação da deficiência do(a) filho(a), procuraremos ter em mente o que nos lembram Stamm \& Mioto (2003): cada família possui sua própria dinâmica, construída e negociada entre seus membros.

Outro fenômeno mutável, pelo seu caráter cultural, é a prevalência da estrutura patriarcal nas relações de gênero. Entretanto, apesar das ressignificações, sua influência ainda permeia nossa civilização, a ponto de autoridade/dominação masculina transcender o âmbito familiar e alcançar outros aspectos da vida social contemporânea, tal como o mercado de trabalho (Giffin, 2002); conforme abordaremos a seguir.

\subsection{2}

\section{Relações de Gênero na Contemporaneidade}

O movimento feminista, que no Brasil emergiu na década de 1970, contribuiu consideravelmente para a redefinição das identidades de gênero, ao conceber as desigualdades entre homens e mulheres como moralmente injustas. Feministas trouxeram à tona a denúncia da profunda opressão social a que as mulheres estavam submetidas, e empenharam-se em desnaturalizar a posição e as tarefas desempenhadas por homens e mulheres na sociedade. Com isso, possibilitaram o entendimento de que é viável intervir nas desigualdades de gênero, uma vez que não se configuram em relações impostas pela natureza, mas sim pela ordem cultural dominante (Silva, 2008).

Orientadas pelo ideal que hoje denominamos de equidade, o movimento feminista reivindicou a participação das mulheres nos tradicionais espaços masculinos. Assim, elas foram assumindo sua posição no mercado de trabalho ${ }^{11}$, o

\footnotetext{
11 A presença das mulheres na força de trabalho remunerado antecede o movimento feminista, porém o fenômeno 'mulher trabalhadora' era 'invisível' historicamente. A contribuição do
} 
que contribuiu para flexibilizar a rígida divisão sexual das tarefas; daí em diante, conquistaram posição social nas práticas econômicas, políticas e educacionais (Sorj, 2003). Todavia, como ressalta Sorj (2003), apesar das inquestionáveis conquistas, o ideal igualitarista está longe de se realizar. Prova disso é que, ainda nos dias de hoje, as condições de vida das mulheres costumam ser mais precárias que a dos homens, dentre as quais, citamos: a renda, as horas trabalhadas, a formalização da ocupação, entre outras.

A desigualdade de gênero na cena contemporânea está demarcada, também, pela inserção das mulheres em tradicionais espaços masculinos e pela menor abertura para a participação dos homens nas tarefas historicamente femininas.

De acordo com Saraiva (1998), dentre os homens existe um grande temor à feminização e, por esse motivo, eles procuram se afastar do que culturalmente diz respeito ao feminino, incluindo o campo da afetividade. Persiste o modelo de virilidade masculina, que se expressa em posse, força, agressividade e determinação. Assim, os problemas devem ser enfrentados com força e coragem, pois o endurecimento deve ser não apenas muscular, mas também psíquico. Para Giffin \& Cavalcanti (2012), esse modelo faz-se presente em todas as esferas da vida do homem: o trabalho, o âmbito sexual e o relacionamento com os filhos.

Essas tradicionais concepções sobre comportamento dos homens vêm criando limites para assunção de novas posições masculinas nas relações de gênero, pois os que buscam romper com o modelo hegemônico de masculinidade podem ser vítimas de preconceitos. Segundo Saraiva (1998), muitos são os que desconfiam dos homens que, procurando incorporar a afetividade à sua identidade masculina, reivindicam participar do cuidado das crianças, por vezes, desconfia-se da sua sexualidade ou associam-no a um abusador ${ }^{12}$.

De acordo com Gomes (1998), a violência de gênero é um aspecto em que se pode perceber que o poder do homem sobre a mulher ainda é uma questão central nas relações de gênero, sobretudo no senso comum. O domicílio pode configurar-se como um espaço violento para a mulher, graças à sua posição

movimento foi justamente a conquista desse reconhecimento social (GIFFIN \& CAVALCANTE, 1999, p.54).

${ }^{12}$ Esta associação entre homem e violência gera toda uma compreensão acerca da masculinidade como desprovida das condições necessárias ao cuidado do outro, principalmente se o outro for uma criança (SARAIVA, 1998). 
subalterna em relação ao homem, e da ampla legitimação social da supremacia masculina.

Outro aspecto característico das diferenças de gênero na atualidade é o comportamento sexual e reprodutivo. Impera a ideia de que o controle da reprodução e da saúde reprodutiva é uma responsabilidade que compete às mulheres. Entretanto, ainda são os homens que detêm maior poder de negociação e decisão sobre a forma e o ritmo das relações sexuais. A pouca participação masculina nos aspectos relacionados à prevenção reflete a construção social dos valores tradicionais associados à masculinidade: agressividade e comportamento de risco (Giffin \& Cavalcanti, 2012).

Os exemplos acima descritos demonstram a permanência das desigualdades nas relações de gênero, com prevalência da autoridade masculina. Entretanto, não se pode mais falar em uma rigidez na configuração das atuais identidades masculinas e femininas. Embora em determinadas circunstâncias do cotidiano social, os indivíduos lancem mão de valores tradicionais como referência para suas ações, a flexibilização das regras sobre os papéis sociais está colocada na cena contemporânea, permitindo, em inúmeras circunstâncias, um afrouxamento das formas de agir dos homens e das mulheres (Gomes, 1998).

Segundo Sorj (2003), a maior aceitação dessa flexibilização das regras e de um ideário igualitarista decorre, principalmente, de indivíduos com níveis mais elevados de instrução e que pertencem a gerações mais jovens. Em sua pesquisa, a autora constatou que "a educação, em particular, se destacou como um vetor importante de aquisição de um sistema de crenças mais igualitário sobre a relação entre os sexos." (Sorj, 2003, p. 87). Ainda segundo Sorj (2003), as novas configurações culturais relacionadas aos papéis de gênero valorizam a independência e a autonomia das mulheres, incentivando-as a inserirem-se no mercado de trabalho. Dessa forma, constatamos que o fenômeno 'mulher trabalhadora' deixou de ser motivo de luta de movimentos em prol dos direitos das mulheres para configurar-se em uma condição amplamente aceita pela sociedade.

De acordo com a literatura (Arriagada, 2006; Giffin, 2002; Araujo \& Scalon, 2003), o processo de incorporação das mulheres no mercado de trabalho remunerado tem gerado consequências muito importantes para as famílias. A primeira é a ampliação do poder de barganha da mulher no ambiente doméstico, 
uma vez que quase sempre a sua contribuição financeira é decisiva para a provisão da casa $^{13}$.

A dimensão econômica é, portanto, relevante para determinar o grau de autonomia feminina. Ter dinheiro e controle sobre ele pode dar maior poder de escolha quanto a manter ou romper uma relação conjugal, por exemplo (Arriagada, 2006).

Segundo Araujo \& Scalon (2003), no aspecto ideológico da nossa sociedade contemporânea, a capacidade de consumo confere status aos indivíduos. Dessa forma, o trabalho remunerado feminino significa, para as mulheres, a aquisição da identidade de consumidoras, o que as valoriza socialmente.

Para Arriagada (2006), a participação feminina no âmbito público possibilita outros avanços e/ou alterações nos tradicionais comportamentos familiares, dentre os quais destacamos: a maternidade como uma opção em vez de um dever; a postergação da primeira união ou do nascimento do primeiro filho; e o decréscimo do índice de reprodução.

Embora tenha sido possível destacar, acima, consideráveis mudanças proporcionadas pela inserção feminina no mercado de trabalho, não se pode ignorar as dificuldades ainda enfrentadas pelas mulheres na esfera pública.

Giffin (2002) sinaliza que a figura da mulher trabalhadora e independente pode permitir o ocultamento da dupla jornada de trabalho ${ }^{14}$ e da sua desvalorização nesse mercado. A respeito da dupla jornada, Ridenti (1998) destaca que diferentemente dos homens, que têm o status definido pelo sucesso profissional, as mulheres tenderão a ser valorizadas somente se conseguirem articular o sucesso do trabalho remunerado com as tarefas domésticas e familiares. As mães trabalhadoras podem até organizar seu dia a dia doméstico contratando empregados, quando a remuneração permitir, mas caberá a elas administrar essa rotina.

Quanto à desvalorização das mulheres no mercado de trabalho, essa afirmação procede do fato de que a maioria das atividades exercidas por elas estão

\footnotetext{
${ }^{13} \mathrm{Na}$ atual realidade das áreas urbanas brasileiras, marcada pela dificuldade crescente dos homens garantirem uma renda familiar adequada, ou mesmo manterem um trabalho minimamente estável, o trabalho extralar remunerado das mulheres está cada vez mais sendo necessário para a provisão da renda familiar (GIFFIN, 2002).

14 Embora a jornada de trabalho remunerado feminina seja em média inferior a dos homens, a diferença não compensa a sobrecarga em tarefas domésticas (CARVALHO et al., 2008).
} 
relacionadas a habilidades domésticas e são mal remuneradas. As mulheres das classes média e alta estão inseridas no mercado em condições e salários melhores que as demais, mas isso não significa que estão em igualdade com os homens de sua classe. São por esses motivos que Giffin (2002) afirma que "a velha divisão sexual do trabalho atravessa a nova reestruturação produtiva e reforça a feminilização da pobreza." (p.3).

A segregação ocupacional das mulheres é um fato inquestionável, na medida em que a maioria dos cargos gerenciais ou executivos em empresas e no governo se mantêm nas mãos de homens (Carvalho et al., 2008), e que as dificuldades femininas de acesso às carreiras não se devem somente aos índices de escolarização ou especialização inferiores aos homens, já que tais problemas permanecem nos casos em que os índices são iguais (Giulani, 2006).

A desvalorização e segregação das mulheres no mercado de trabalho são fatores comprobatórios da persistência de valores tradicionais na esfera pública. E as dificuldades enfrentadas no que se refere à equidade nas relações de gênero, também se fazem presentes no âmbito privado. Essa afirmação é corroborada por Durham (1983) ao identificar, em sua pesquisa, que as ocupações remuneradas das mulheres, mesmo quando indispensáveis para o orçamento familiar, são definidas como mera ajuda ao marido, visto que a provisão do lar ainda é concebida como responsabilidade deste.

Buscaremos, a seguir, enveredar pela discussão acerca da esfera privada, com foco nas famílias brasileiras contemporâneas. Levaremos em consideração a influência ideológica das relações de gênero na divisão das atividades familiares; evitando, contudo, naturalizar os papéis assumidos por homens e mulheres e reforçar a existência de um modelo ideal de família.

\subsection{3}

\section{Famílias Brasileiras Contemporâneas e a Influência Ideológica das Relações de Gênero}

Compreendemos que uma adequada definição para o termo 'família' é a elaborada por Elsen et al (2009, p. 6, Apud Stamm \& Mioto, 2003): 
Unidade dinâmica constituída por pessoas que se percebem como família, que convivem por determinado espaço de tempo, com estrutura e organização para atingir objetivos comuns e construindo uma história de vida. Os membros da família estão unidos por laços consanguíneos, de adoção, interesse e ou afetividade. Tem identidade própria, possui e transmite crenças, valores e conhecimentos comuns influenciados por sua cultura e nível socioeconômico. A família tem direitos e responsabilidades, vive em um determinado ambiente em interação com outras pessoas e familiares em diversos níveis de aproximação. Define objetivos e promove meios para o crescimento, desenvolvimento, saúde e bem estar de seus membros.

Essa definição parece-nos apropriada porque considera a formação das famílias a partir da percepção das pessoas envolvidas, possibilitando variações mais condizentes com a diversidade de arranjos familiares atualmente existentes, em vez de levar em conta um exclusivo modelo pré-determinado. Entretanto, não a consideramos completa, pois ignora a existência de famílias unipessoais.

A atual tendência à pluralidade de arranjos familiares está vinculada, de acordo com Berquó (1989), ao fato de que a união das pessoas traduz-se, cada vez mais, em coisa privada, baseada nos sentimentos mútuos de cada um.

Também discutindo acerca da diversidade de famílias contemporâneas e dos novos padrões de conjugalidade, Araujo \& Scalon (2003) observam que, a partir da década de 1970, as famílias brasileiras ficaram menores, já que aumentaram as famílias compostas por apenas um indivíduo, as compostas por apenas um dos pais (monoparentais), as formadas por casais do mesmo sexo, e as constituídas por casais sem filhos. Reduziram-se, portanto, as famílias extensas e as nucleares.

Com exceção das famílias formadas por homossexuais, a diversidade de arranjos existentes na cena contemporânea brasileira foi formalmente reconhecida a partir da publicação da Constituição de 1988. Para a Carta Magma, o casamento formal deixou de ser fundamental para a formação de uma família. A entidade familiar passou a ser constituída pela união estável entre o homem e a mulher ou pelas famílias monoparentais, em que o homem ou a mulher assume as responsabilidades.

Do ponto de vista das relações de gênero, essa existência de novos arranjos familiares coloca em questão a hegemonia da família nuclear, como observado por Stamm \& Mioto (2003), e possibilitam o enfraquecimento da autoridade patriarcal, como lembrado por Araujo \& Scalon (2003). Um dos indícios desse enfraquecimento - nomeado por Castells (2000) de crise da família patriarcal - é 
o acentuado número de divórcios e de separação dos casais, que indica a dissolução do laço conjugal, geralmente orientada pela dimensão do afeto. Essa realidade difere da sociedade tradicional, que possuía o modelo familiar baseado no comprometimento duradouro entre seus membros.

As transformações históricas incluem, também, a flexibilização da ideologia tradicional que levava mães não casadas a abandonarem filhos por pressões sociais $^{15}$ - embora o abandono continue a ser uma realidade, decorrente basicamente da pobreza (Carvalho et al., 2008).

As citadas tendências de fragilidades de uniões e de assunções de filhos por mães solteiras, bem como: a queda acentuada da fecundidade, o aumento da longevidade da população e a diferença de taxa de mortalidade entre os sexos que levam à formação de novas estruturas domésticas, tais como os lares de solteiros ou lares com apenas um dos pais - comprometem ou cessam a autoridade patriarcal sobre a família, ainda que, ideologicamente, mantenha-se a reprodução da dominação masculina (Castells, 2000).

Berquó (1989) propõe um enfoque demográfico para a compreensão dessas tendências contemporâneas que vêm afetando o tamanho, a estrutura e a função dos integrantes das famílias brasileiras. Segundo a autora, o aumento das separações leva a um aumento dos lares monoparentais. E como a guarda dos filhos, em geral, fica com as mães, incorre no predomínio de famílias monoparentais chefiadas por mulheres. A maior incidência de viuvez entre as mulheres também contribui para essa condição de chefia feminina do lar.

No Brasil, vem crescendo a preferência pela união consensual. Segundo Berquó (1989), no passado, esse tipo de união esteve mais presente em estratos mais pobres da população; atualmente, essa opção de vida conjugal começa a atrair pessoas de outras classes, fundamentalmente os segmentos mais jovens. Isso comprova uma ruptura com valores e normas tradicionais ligadas ao matrimônio.

Outro aspecto destacado pela autora, no que se refere ao processo de mudança no comportamento das pessoas, é a ampliação do contingente de nascimentos fora do casamento; com a característica peculiar de que muitos deles

\footnotetext{
${ }^{15}$ Os abandonos de crianças no Brasil encontravam justificava no cristianismo. Para a moral cristã, as práticas reprodutivas estavam restritas ao casamento formal, portanto, a procriação fora do matrimônio condenava as mulheres a sanções morais e religiosas. Os asilos para essas crianças comumente a roda dos expostos - eram considerados uma boa forma de as mulheres, arrependidas do pecado, poderem levar uma vida digna (GONÇALVES, 1987).
} 
são desejados e planejados. Vivenciar a maternidade como uma necessidade não vinculada à tradicional instituição familiar está presente em planos de algumas mulheres, sobretudo as financeiramente independentes, o que significa uma ruptura com modelos mais tradicionais de família.

Bilac (1995) também se propõe a analisar as mudanças ocorridas nas famílias, porém tomando como referência as diferenças entre classes sociais. Segundo a autora, as camadas populares brasileiras valorizam o modelo de família nuclear - pai trabalhador, mãe em casa e criança na escola -, mas suas possibilidades de efetivá-lo restringem-se a poucos, uma vez que é necessário um nível mínimo de participação social para que esse modelo seja possível: acesso ao trabalho regular, à moradia e à escola. $\mathrm{O}$ retrato mais fidedigno dessas famílias, que são constantemente ameaçadas pela precariedade dos empregos, é o de se ampliarem para abrigar parentes e de recorrerem ao trabalho feminino, embora mais precário que dos homens. Ainda de acordo com Bilac (1995), o contingente elevado de famílias chefiadas por mulheres nessas camadas não comprova o favorecimento ao exercício de um modelo alternativo de relações familiares, mas sim a impossibilidade de realização do modelo preferencial: o da tradicional família nuclear.

Diferentemente das classes populares, as camadas médias da população não têm problemas de participação social que conduziriam à impossibilidade de realização do modelo tradicional. Contudo, o crescente número de divórcios comprova que algo está levando ao não cumprimento prático desse modelo. Uma das explicações pode residir na maior escolarização das mulheres (Bilac, 1995).

As classes médias urbanas apresentam maior predisposição para relações mais igualitárias no que se refere à divisão de papéis de gênero. Essa prevalência, quando comparada aos setores empobrecidos da população, pode ser explicada pelo "nível mais alto de escolaridade, maior acesso às informações, inclusive às teorias psicanalíticas e pedagógicas” (Ridenti, 1998, p.4). Não significa, porém, que todos os componentes dos setores de baixa renda não possam apresentar novos padrões de comportamento quanto às tarefas desempenhadas por homens $\mathrm{e}$ mulheres; não se trata de uma representação da totalidade (Ridenti, 1998). 
No âmbito da esfera privada, já é possível verificar aspectos bastante inovadores dos comportamentos familiares: homens exercendo a paternagem ${ }^{16}$, querendo decidir sobre quando e como ter filhos e reivindicando a guarda dos seus filhos ou a adoção de crianças, mesmo sendo solteiros; e mulheres não aceitando passivamente a dupla jornada de trabalho e construindo projetos para além da maternidade (Ridenti, 1998).

São por exemplos como os descritos acima que se pode legitimar a afirmação de Araujo \& Scalon (2003): "no Brasil as relações de gênero na família mudaram" (p. 66). Entretanto, como descrito pelas mesmas autoras, acompanhando os traços gerais dessa tendência mundial, as famílias ainda mantêm, "na natureza de sua interação, o princípio tradicional da divisão sexual do trabalho - mulheres e homens com papéis diferenciados - e a predominância do padrão de domesticidade, que confere desvantagens às mulheres na vida social em geral." (Araujo \& Scalon, 2003, p. 66).

A sociedade contemporânea é, portanto, marcada por um período de 'embate' entre a herança conservadora e as concepções contemporâneas (Castells, 2000), uma sobrepondo-se à outra em determinados momentos da vida social e em determinados contextos familiares.

As continuidades da herança conservadora no âmbito familiar são demarcadas, fundamentalmente, pelo fato de que os homens continuam sendo percebidos como provedores e as mulheres como cuidadoras da família. Dessa forma, como discutido por Ridenti (1998), em geral, só é permitido aos homens a assunção dos espaços tradicionalmente femininos se eles mantiverem a provisão como o seu papel principal. Por mais que se encontrem pais reivindicando o que Costa (2002) nomeia de dimensões femininas na masculinidade, o trabalho remunerado e o sustento dos filhos continuam sendo considerados os papéis definidores de suas identidades masculinas e paternas.

\footnotetext{
${ }^{16}$ A paternagem está relacionada à vinculação afetiva. Trata-se de um pai que seja participante em todos os aspectos do cuidado do bebê. Também se espera dele um envolvimento mais ativo no cuidado e na educação dos seus filhos em todas as idades e não apenas no suporte econômico da família (LYRA, 2010).
} 
No que se refere às mulheres, como já discutido, por mais que tenham conquistado autorização social $^{17}$ para atuar na esfera pública, terão essa atuação legitimada se conciliarem o trabalho remunerado com as tarefas de execução ou administração dos cuidados da casa e da família. Assim, “o status feminino ainda está marcado pelo sucesso em articular o trabalho e a família” (Ridenti, 1998, p. $11)$.

A presença das mulheres no mercado de trabalho goza de plena aceitação social - ainda que suas contribuições financeiras para o sustento da família sejam consideradas uma ajuda para o marido (nos casos em que o marido existir). Entretanto, como relata Sorj (2003), a contribuição masculina nas atividades domésticas não goza da mesma legitimidade.

Segundo Araujo \& Scalon (2003), chega a ser surpreendente o fato de haver atividades domésticas praticamente inexploradas pelos homens, tais como lavar roupa, passar e cozinhar. Essas práticas demonstram que "a divisão sexual do trabalho doméstico ainda continua sendo amplamente dominada pelo padrão tradicional." (Araujo \& Scalon, 2003, p. 47).

Assim, hegemonicamente, os homens continuam a desempenhar papel secundário e bastante seletivo no que se refere à realização das demais tarefas concernentes ao espaço doméstico (Carvalho et al., 2008). Entretanto, Araujo \& Scalon (2003) ressaltam que é "no envolvimento masculino com os filhos que se percebe um quadro mais positivo." (p. 50).

Considerando o exposto, podemos concluir que, hegemonicamente, o trabalho relacionado com a reprodução social permanece como responsabilidade feminina, ainda que isso signifique sobrecarga na jornada das mulheres inseridas no mercado de trabalho. Já os homens, ocupam papel secundário no espaço doméstico; porém, ainda que de forma incipiente, o cuidado masculino dos filhos começa a ser visualizado.

A participação das crianças no interior das famílias também é uma questão a ser considerada, quando se pensa em avanços e continuidades do modelo tradicional de família. As crianças brasileiras têm legalmente assegurado o

\footnotetext{
17 Autorização social é o termo utilizado por Nolasco (1993) para denominar as mudanças de concepções sociais necessárias para que os homens participem de atividades até então consideradas femininas e mulheres participem das atividades consideradas masculinas.
} 
reconhecimento de que são sujeitos de direitos ${ }^{18}$; entretanto, como descrito por Oliveira (2011), na prática, muitas vezes, elas são tidas como propriedades de seus pais, o que nos remete à lembrança da subordinada posição tradicionalmente atribuída aos filhos nas famílias. Essa permanente imagem de submissão confere aos pais legitimidade social para tomar todas as decisões acerca da vida das crianças, sem que essas sejam respeitadas e ouvidas em seus desejos e opiniões. Esse argumento parece-nos importante para nossa pesquisa porque, segundo Neves (2011), no imaginário social, as pessoas com deficiência, são tratadas como crianças - sobretudo as com deficiência intelectual - e essa infantilização pode tirar-lhes a legitimidade para fazer escolhas acerca de suas próprias vidas.

Partiremos, a seguir, para discussão sobre os reflexos das políticas sociais na vida das famílias brasileiras, a fim de que tenhamos elementos para analisarmos os reflexos dessas políticas nas famílias de pessoas com deficiência.

\section{2 Políticas Sociais e os Reflexos nas Famílias Brasileiras}

A instituição Família ganhou relevância atual pelo seu caráter informal e pelo preponderante desejo de cuidar e predisposição para proteger, educar e até fazer sacrifícios em prol de seus membros (Pereira, 2006). Esse suposto altruísmo familiar vai ao encontro dos interesses das políticas sociais vigentes.

As políticas sociais brasileiras foram construídas tomando como base a concepção de que as famílias devem ter a capacidade de proteger seus integrantes. Essa crença conduziu a uma distinção entre famílias capazes e incapazes. As capazes são consideradas aquelas que, via mercado de trabalho e organização interna, conseguem desempenhar com êxito as funções que lhes são atribuídas pela sociedade. As incapazes são as que, não conseguindo atender às expectativas sociais, requerem interferência externa, a princípio do Estado, para a proteção dos

\footnotetext{
${ }^{18}$ O Estatuto da Criança e do Adolescente, promulgado em 1990, instituiu a ideia da criança e do adolescente como sujeitos de direitos (RIZZINI et al., 2007). Com essa legislação, a população infanto-juvenil passou a ser percebida, legalmente e em sua totalidade, como pessoas em condição peculiar de desenvolvimento e deixou de ser apresentada como simples objeto de tutela para tornar-se sujeito com direitos a serem garantidos (JUNIOR, 1992).
} 
seus membros. Assim, são percebidas como merecedoras de ajuda pública, as famílias que falharem nas responsabilidades de cuidado e proteção interna (Mioto, 2006).

Conforme Mioto (2006) e Maia et al. (2007) afirmam, a atenção Estatal às famílias tem ocorrido especialmente por meio da centralização de recursos em programas de apoio sociofamiliar que as atendem em situações-limites, tais como profunda miséria e desnutrição. Instaurou-se uma cultura assistencialista defensora de que as necessidades dos cidadãos devem ser providas pela família e que o Estado só deve intervir na falha desses. A lógica recorrente das políticas sociais tem sido, portanto, a da cidadania invertida: o acesso aos programas implica a comprovação do fracasso dos indivíduos (Mioto, 2006).

Poucos programas têm se voltado para as dificuldades cotidianas das famílias, a fim de dar subsídios para que elas consigam superar momentos críticos de sua existência, evitando que cheguem a vivenciar situações-limites (Mioto, 2006).

Pereira (2006) defende que o objetivo das políticas sociais em relação às famílias não deveria ser o de pressionar as pessoas para que assumam responsabilidades além de suas forças e alçadas, mas de oferecer-lhes alternativas realistas de participação cidadã. Para tanto, o Estado tem de se tornar partícipe daquilo que só ele tem como prerrogativa: a garantia de direitos. Isso não significa, segundo a autora, a desconsideração da chamada solidariedade informal própria da família, mas a consideração de que essas formas de proteção familiar não devem ser irreais a ponto de lhes serem exigidas participações descabidas e impraticáveis.

Carvalho (2003) também critica a desresponsabilização do Estado da função de assegurar a proteção social aos cidadãos e a sua tendência de atribuir exclusivamente às famílias essa responsabilidade. A autora não desconsidera a importância dessa instituição para a proteção, socialização e criação de vínculos relacionais; no entanto, considera que tais papéis só podem ser reivindicados caso entendam-se que as famílias carecem de proteção Estatal. E para que isso seja possível, na opinião da autora, são necessárias as seguintes atenções do Estado às famílias: acolhimento e escuta pelos serviços públicos; rede de serviços de apoio psicossocial, cultural e jurídico; programas de complementação de renda; e programas de geração de trabalho e renda. 
O marco legal brasileiro conta com a Política Nacional de Assistência Social, de cuja proposta condiz com as perspectivas defendidas pelos autores que advogam pela proteção social do Estado às famílias que dela necessitarem (Carvalho, 2005; Pereira, 2006; Mioto, 2006). Essa Política propõe dar subsídios às famílias para que cumpram o papel de proteção dos seus membros, contribuindo com a inclusão e a equidade, e ampliando o acesso a bens e serviços socioassistenciais (Brasil, 2004).

Essa legislação não condiz, entretanto, com a realidade cotidiana das ações Estatais, pois o que predomina são intervenções pontuais em casos extremos. Essa afirmação encontra fundamento em Silva (2008), que analisou a atenção às famílias de pessoas com deficiência e concluiu que o Estado intervém apenas quando a pessoa deficiente não possui vínculos familiares e se encontra em situação de vulnerabilidade social extrema ou, ainda, quando a família não dispõe de recursos básicos para exercer o cuidado a essa pessoa. Neste último caso, pode ser concedido o Benefício de Prestação Continuada (BPC) ${ }^{19}$.

A verdadeira intervenção Estatal tende a excluir, portanto, famílias de pessoas com deficiência que, apesar de necessitarem de suporte, não se enquadram na condição de vulnerabilidade extrema. Conforme constata Silva (2008), esse é o caso de muitas mulheres cuidadoras de pessoas com deficiência, que se encontram desprotegidas pelas Políticas Públicas. Quando tentam conciliar trabalho remunerado e cuidado do filho com deficiência, elas frequentemente sobrecarregam-se; se optam por deixar o trabalho remunerado para cuidar do filho, não recebem por isso; e se a pessoa com deficiência vier a falecer, elas não têm direito a garantias previdenciárias.

As pessoas que compõem as camadas médias brasileiras podem ter suas condições de sustentabilidade comprometidas por essa falta de apoio Estatal. Por não vivenciarem situações-limites, esse público costuma ser excluído do acesso às políticas sociais, fundamentalmente as de assistência. E, como destaca Bilac (1995), a própria precariedade dos serviços públicos, como os de saúde e educação, conduz famílias das classes médias a buscarem tais recursos na rede privada, o que eleva os custos da reprodução.

${ }^{19} \mathrm{O}$ BPC é a garantia de 1 (um) salário mínimo mensal à pessoa com deficiência e ao idoso (acima de 65 anos) que comprovem não possuir meios de prover a própria manutenção e nem de tê-la provida por sua família (BRASIL, 1993). 
Tal consideração torna-se relevante para nossa pesquisa se levarmos em conta que as famílias de classe média que possuem filhos com deficiência - das quais se incluem os nossos sujeitos - terão uma dificuldade ainda maior em seus custos de reprodução, uma vez que as necessidades específicas das pessoas com deficiência tendem a encarecer os tratamentos, medicamentos, escola e alimentação. Assim, o custo orçamentário gerado pela proteção familiar à pessoa com deficiência pode comprometer o padrão de consumo familiar ${ }^{20}$, sobretudo se um dos membros da família deixar o trabalho remunerado para dedicar-se ao cuidado dessa pessoa; o que tende a ser uma ação praticada pela mulher (Almeida, 2011).

A percepção sobre essa redução dos padrões de consumo de famílias de pessoas com deficiência leva-nos a reiterar a afirmação da ausência do Estado na garantia de condições de sustentabilidade para as famílias, a fim de que elas possam prevenir, proteger, promover e incluir seus membros, conforme preconiza a Política Nacional de Assistência Social (Brasil, 2004).

\section{3 \\ Funcionamentos de Famílias em Situações de Mudança}

Enveredamos, nesta seção, pelo referencial teórico que discorre acerca do funcionamento das famílias e de como essas lidam com mudanças consideradas críticas.

A respeito de como o viver em família funciona, Szymansky (2012) alerta para a existência de uma dualidade, que foi por ela denominada de 'família vivida' e 'família pensada'. A família pensada diz respeito a um modo considerado ideal de viver, com regras e diretrizes que supostamente teriam de ser seguidas pelos integrantes da família. Esse modelo ideal é constituído por bases que advêm da cultura da sociedade - transmitida entre gerações - e da cultura familiar, visto que cada família forma suas próprias regras, ritos e jogos.

\footnotetext{
${ }^{20}$ Por padrões de consumo familiar entendemos a capacidade financeira de uma família escolher e consumir bens e serviços mercantilizados (BILAC, 1995).
} 
Szmansky (2005) identifica que o modelo de família brasileiro tido como ideal tende a ser o da família nuclear burguesa, já que esse permanece arraigado no imaginário social. Assim, a 'família pensada' é aquela constituída pela união exclusiva de um homem e uma mulher, com compromisso de acolhimento e cuidado para com as pessoas envolvidas; essa família funciona dentro de uma ordem estabelecida de autoridade do homem/pai e, nesse contexto, pressupõe-se uma estabilidade do modelo pai-mãe-filhos. A autora ressalta que as famílias que não conseguem viver nesse padrão podem ser percebidas, por elas mesmas e pela sociedade, como desestruturadas, incompetentes e inferiores.

Entretanto, a 'família vivida', a que de fato existe, tende a diferir da 'pensada' porque, no agir concreto do cotidiano, as regras do modelo burguês nem sempre são seguidas (Szmansky, 2012). "Se, no discurso, elas não são contestadas, o mesmo não ocorre na ação que, aberta ou veladamente, aponta muitas vezes para a direção oposta a do pensado." (Szmansky, 2012, p. 36). Exemplos de 'família vivida' são a flexibilidade de papéis entre homens e mulheres existentes na vida cotidiana de algumas famílias, bem como os diferentes arranjos familiares hoje existentes.

Embora a família que se vive possa diferir muito do modelo estruturado de família nuclear burguesa, isso nem sempre significa sua aceitação ideológica como alternativa. O modelo de família pensada permanece impondo normas de conduta e desvalorizando o que foge desse padrão (Szmansky, 2012).

Ao considerarmos que a dicotomia entre o vivido e o pensado pode gerar sensação de inadequação entre as famílias que não correspondem ao modelo ideal, questionamos se a 'família pensada' pode configurar-se num elemento complicador para os processos de (re)organização de famílias a partir da constatação da deficiência do(a) filho(a), uma vez que a existência desse(a) filho(a) as distancia do modelo familiar geralmente idealizado.

Outro importante referencial teórico para discussão sobre funcionamento das famílias e, portanto, relevante para reflexão acerca do nosso objeto de estudo, advém de Minuchin (1982), que revela uma visão sistêmica de família. O autor parte do entendimento de que a família é um sistema social capaz de influenciar os indivíduos nele inseridos. No entanto, cada indivíduo também influencia o seu contexto, contribuindo para gerar mudanças nas ações e pensamentos dos demais 
integrantes do sistema. Desta forma, o autor defende que a compreensão acerca dos indivíduos de um sistema familiar só é possível se o todo for levado em conta.

$\mathrm{O}$ autor esclarece que "as mudanças numa estrutura familiar contribuem para mudanças no comportamento e nos processos psíquicos internos dos membros desse sistema" (Minuchin, 1982, p. 19). Dessa forma, tomando como referência a argumentação de Minuchin (1982), podemos afirmar que alterações no contexto familiar provocam mudanças em cada indivíduo, o que nos instiga a defender a importância de conhecer as implicações da deficiência de um filho para cada integrante da família.

A deficiência de um filho pode configurar-se em mudança significativa para o sistema familiar, o que vai gerar necessidades de reorganizações psíquica e comportamental. Entretanto, provavelmente, essa não será a primeira mudança ocorrida na vida da família; antes da existência da pessoa com deficiência, seus integrantes podem ter passado por vários outros processos de influência mútua e de adaptação. Minuchin (1982) apoia-nos na compreensão sobre como, em geral, as famílias vão se adaptando e acomodando em seu processo de formação e de como os estresses são inerentes a estes processos.

Segundo Minuchin (1982), o casal recém-formado vivencia um processo de acomodação mútua. Cada cônjuge forma uma rede invisível de exigências, que servirá para controlar o comportamento um do outro e para regular muitas situações familiares. O casal também enfrenta a tarefa de separar-se da família de origem e de negociar uma relação diferente com os integrantes dessa antiga família. "As lealdades devem mudar, porque os compromissos fundamentais dos novos esposos são com seu matrimônio. As famílias de origem devem apoiar esta ruptura." (Minuchin, 1982, p. 26). Da mesma maneira, cada cônjuge deve reorganizar o convívio com o que é extrafamiliar - trabalho, deveres e prazeres selecionando o que do mundo externo poderá permanecer na vida da nova família.

Ainda em relação ao processo de acomodação das famílias, Minuchin (1982) esclarece que o nascimento de uma criança é um marco, pois caracteriza uma mudança radical na organização familiar. As funções do casal devem ser adaptadas para o atendimento às necessidades da criança, fundamentalmente em termos de cuidado e alimentação. A criança representa um novo subsistema nesse sistema familiar, influenciando os demais e sendo por eles influenciada. A chegada desse novo subsistema também requer uma renegociação com os 
integrantes das famílias de origem e com o contexto exterior, para que esses apoiem as novas funções do sistema familiar. Entretanto, também há a possibilidade de fortalecimento dos limites em torno da família nuclear.

Após o nascimento do filho, a família terá muitos outros motivos para se adaptar e reestruturar: quando a criança torna-se adolescente e adulta; a chegada dos irmãos; quando os pais tornam-se avós; e daí em diante. As mudanças requerem acomodação contínua e "devem apoiar e encorajar o crescimento de todos os seus membros, enquanto se adaptam a uma sociedade em transição. Estas tarefas não são fáceis." (Minuchin, 1982, p.27). Pensamos que as dificuldades de adaptação do sistema familiar podem tornar-se ainda maiores quando um dos filhos é uma pessoa com deficiência, seja pelo preconceito social, seja pela dificuldade de aceitação da própria família e/ou pelas limitações impostas pela condição da deficiência. É por este motivo que julgamos ser possível classificar a constatação da deficiência de um filho como uma crise imprevisível.

É Minuchin (1982) quem propõe uma distinção entre crises previstas e imprevisíveis. Ambas as crises geram tensões e deflagram reordenamento dos comportamentos e das relações, entretanto as dificuldades de adaptação às crises imprevisíveis são maiores. As crises previstas são esperadas e decorrem do próprio processo de desenvolvimento da família e de seus membros individuais: matrimônio, nascimento de um filho, a passagem do filho para a adolescência e para a vida adulta, o casamento de um filho, a chegada de netos, entre outros. Essas crises impactam o sistema familiar, mas tendem a ser superadas mais facilmente, com seus próprios recursos internos. Já as crises imprevisíveis, as não esperadas, representam maior estresse para o sistema e deflagram a necessidade de mobilizar recursos externos para a sua superação. É por isso que partimos do entendimento de que a descoberta da deficiência de um filho pode ser considerada uma crise imprevisível, pois funcionará como um agente estressor e demandará apoio da família ampliada e dos sistemas externos, tais como a rede de apoio social.

Uma característica peculiar à situação da deficiência é o fato de que a crise pode ser ampliada com o passar do tempo. Inicialmente, a adaptação da família à descoberta da deficiência do filho pode ocorrer sem grandes dificuldades; porém, o estresse da família e os problemas de adaptação podem ampliar-se à medida que a pessoa com deficiência cresce e a deficiência torna-se mais evidente. Trata-se do 
que Minuchin (1982) denomina de estresses em torno de problemas idiossincrásicos: “(...) uma família com filho retardado pode ter sido capaz de se adaptar aos problemas colocados, quando a criança era pequena. Mas a realidade do retardamento, que os pais eram capazes de evitar, enquanto a criança era pequena, deve ser enfrentada à medida que cresce e a disparidade de desenvolvimento entre ela e seus iguais se torna mais evidente." (Minuchin, 1982, p. 69).

Seja via crise prevista ou imprevisível, o fato é que o sistema familiar está constantemente em processo de transformação, adaptando-se às diferentes exigências de desenvolvimento que lhe são impostas. Além da pressão interna, que promove mudanças no sistema e nos indivíduos que o compõem, também existe a pressão externa, formada pelas instituições sociais significativas, com forte impacto sobre os membros do sistema familiar (Minuchin, 1982). Tais influências extrafamiliares também são consideradas por Bronfenbrenner (1996).

Bronfenbrenner (1996, Apud Oliveira, 2011) alerta para a necessidade de os pesquisadores, ao investigarem sobre dinâmicas familiares, buscarem compreender a influência de agentes exteriores sobre o grupo familiar. $\mathrm{O}$ autor formula o modelo ecológico do desenvolvimento humano, segundo o qual a família é concebida como um microssistema. Esse microssistema, ou unidade funcional, é o primeiro espaço no qual o ser humano em desenvolvimento interage e adquire um padrão de papéis e comportamentos determinados, de acordo com o meio social mais amplo em que está inserido. Esse sistema familiar recebe influências de outros sistemas, o que pode contribuir para facilitar ou dificultar o seu desenvolvimento. Esses sistemas externos ao microssistema familiar são denominados pelo autor de mesossistema, exossistema e macrossistema.

O mesossistema é caracterizado pelos espaços de interação ativa e frequente das famílias, como a escola e a vizinhança. No exossistema, estão incluídos ambientes nos quais apenas um ou mais membros da família mantém relações diretas, ainda que essa interação tenha efeito sobre toda a família, tal como o trabalho e as redes de apoio social. O macrossistema é o mais amplo, consistindo em ideologias, valores, crenças e organização social comum à determinada cultura (Bronfenbrenner, 1996, Apud Oliveira, 2011).

No que se refere ao campo de interesse desta dissertação, tais concepções de sistemas são importantes para auxiliar-nos a compreender os tipos de influências 
que podem afetar os processos de (re)organização de famílias de pessoas com deficiência; sejam influências que contribuam para adaptação das famílias à nova realidade, ou que criem empecilhos para o reequilíbrio familiar, influenciando nos cuidados do(a) filho(a). As redes de apoio social, que compõem o exossistema, são, em princípio, consideradas agentes influenciadores da adaptação, por contribuírem para facilitar a atividade familiar de cuidado da pessoa com deficiência (Bastos \& Deslandes, 2008). Essa discussão acerca da categoria ‘cuidado’ será abordada no capítulo seguinte. 


\section{2 \\ O Cuidado em Foco: Principais Aspectos da Atividade de Cuidar}

O conhecimento dos processos de (re)organização das famílias a partir da constatação da deficiência do(a) filho(a), no que se refere ao cuidado da prole, implica na necessidade de enfocarmos a categoria 'cuidado', por meio da identificação dos aspectos diversos que envolvem a atividade de cuidar.

Iniciaremos a discussão com aspectos gerais, que abrangem o cuidado profissional e familiar a todos os que deles necessitam; e culminaremos na identificação de aspectos específicos que envolvem o cuidado familiar das pessoas com deficiência, a fim de que possamos aproximar-nos, ao máximo, do nosso objeto de estudo.

Boff (2011) define o cuidado a partir da origem dessa palavra. Ela é derivada do latim cura, que expressava uma atitude de cuidado, desvelo, preocupação e inquietação pela pessoa amada ou por um objeto de estimação. Logo, para o autor, cuidado significa "desvelo, solicitude, diligência, zelo, atenção, bom trato" (Boff, 2011, p. 91).

Souza (2003), ao investigar o significado atribuído pelos pais e mães ao cuidar de um filho com deficiência mental, define o cuidado como a responsabilidade sentida em relação aos filhos; sentimento que os conduz aos desejos de tomar conta, ter cautela e zelar pelos filhos.

Entendemos que o cuidado extrapola o desejo citado por Souza (2003), significando a efetiva ação em prol de outrem. Desta forma, a conceituação de que estamos nos apropriando aproxima-se da apresentada por Araujo \& Scalon (2003), que entendem por cuidado "a provisão diária de atenção social, física, psíquica e emocional às pessoas".

Tronto (1997) parece corroborar essa linha de pensamento, ao afirmar que cuidado implica responsabilidade e compromisso contínuos. Entretanto, o autor não centraliza o cuidado nas pessoas, mas também nas coisas; assim, para ele o compromisso contínuo pode ser com alguém ou com alguma coisa. Tronto (1997) segue nessa discussão argumentando que, dependendo do objeto do cuidado, 
podemos ter 'cuidado com' ou 'cuidado de'. O 'cuidado com' refere-se a objetos menos concretos, caracterizando-se como uma forma mais geral de compromisso. Já o 'cuidado de' envolve responder às necessidades específicas (concretas, físicas, espirituais, intelectuais, psíquicas e emocionais ${ }^{21}$ ) de si mesmo ou de outras pessoas. Em nossa sociedade, o 'cuidar de' seres humanos localiza-se especialmente nas famílias, e é essa forma de cuidado que enfocaremos neste estudo, dando especial ênfase ao cuidado de pessoas com deficiência.

\section{1 \\ Dimensões Macro e Micro da Atividade de Cuidar}

A contribuição de Boff (2011) para a temática do cuidado passa por uma dimensão macro, vinculada a uma visão ecológica - integral, social e ambiental e por uma dimensão micro, que está relacionada ao cuidado entre os seres humanos (Silva et al., 2005).

Ao defender que a essência da humanidade encontra-se basicamente no cuidado, Boff (2011) revela sua preocupação com a sociedade contemporânea, que vem ameaçando a vida humana ao criar a solidão entre as pessoas. $\mathrm{O}$ cuidado está cada vez mais distante nesta sociedade de caráter virtual, que comporta o encapsulamento sobre si mesma, o descarte das pessoas concretas e a falta de contato com o outro. Como solução do problema da falta de cuidado denominada pelo autor de descuido - o autor defende o princípio inspirador de um novo paradigma de convivência, no sentido amplo de respeito e preservação de tudo o que existe na terra.

Para Boff (2011), estamos vivendo uma crise civilizacional, a qual aparece sob o fenômeno da falta de cuidado. Pode-se inferir, a partir do discurso do autor, que o descuido é agravado pela hegemonia do individualismo, gerador do menosprezo à tradição da solidariedade e do descaso pelas vulnerabilidades de diversos segmentos da população, tais como os pobres e deficientes. Isso

\footnotetext{
${ }^{21}$ As necessidades físicas e psíquicas, a que o autor se refere, podem ser exemplificadas como: alimento, calor, conforto e outros. São necessárias ações humanas para satisfazer essas necessidades e a forma de atendê-las pode variar entre sociedades (TRONTO, 1997).
} 
significa, pela perspectiva de Boff (2011), que estamos contrariando a própria essência do ser humano.

É na publicação "Ser e Tempo" de Martin Heidegger (1889-1976), que Boff (2011) ancora-se para explicar o cuidado como essência da humanidade. Isso significa que, do ponto de vista existencial, o cuidado encontra-se na raiz primeira do ser humano, na sua natureza, antes que ele faça qualquer coisa. Essa essencialidade pode ser explicada pelo fato de que:

Se não receber cuidado desde o nascimento até a morte, o ser humano desestruturase, definha, perde o sentido e morre. Se, ao largo da vida, não fizer com cuidado tudo o que empreender, acabará por prejudicar a si mesmo e por destruir o que estiver à sua volta (Boff, 2011, p.34).

Desta forma, o ser humano é definido como um ser de cuidado por colocar cuidado em tudo o que projeta e faz. É descoberto como ser-no-mundo-com-osoutros $^{22} \mathrm{e}$, como tal:

Sempre se relacionando, construindo seu habitat, ocupando-se com as coisas, preocupando-se com as pessoas, dedicando-se àquilo que lhe representa importância e valor e dispondo-se a sofrer e a alegrar-se com quem se sente unido e ama (...). (Boff, 2011, p. 35)

Nesse sentido, a dimensão do cuidado nunca poderá ser totalmente desvirtuada da humanidade, pois sem cuidado não há como haver ser humano (Boff, 2011).

A fábula-mito do cuidado essencial ${ }^{23}$, de origem latina, é abordada pelo autor como um meio de dar continuidade à defesa da tese de que o cuidado é a

\footnotetext{
${ }^{22}$ Boff (2011) esclarece que ser-no-mundo significa uma forma de coexistir e conviver com todas as coisas do mundo. A relação com as coisas não é, portanto, de dominação, mas de convivência. Nessa navegação e nesse jogo de relações, o ser humano vai construindo seu próprio ser, sua autoconsciência e sua própria identidade.

${ }^{23}$ Versão livre em português da fábula mito sobre o cuidado, disponível em Boff (2001, p. 46): "Certo dia, ao atravessar um rio, Cuidado viu um pedaço de barro. Logo teve uma ideia inspirada. Tomou um pouco do barro e começou a dar-lhe forma. Enquanto contemplava o que havia feito, apareceu Júpiter. Cuidado pediu que soprasse espírito nele. O que Júpiter fez de bom grado. Quando, porém Cuidado quis dar um nome à criatura que havia moldado, Júpiter o proibiu. Exigiu que fosse imposto o seu nome. Enquanto Júpiter e Cuidado discutiam, surgiu, de repente, a Terra. Quis também ela conferir seu nome à criatura, pois fora feita de barro, material do corpo da Terra. Originou-se então uma discussão generalizada. De comum acordo pediram a Saturno que funcionasse como árbitro. Ele tomou a seguinte decisão que pareceu justa: 'você Júpiter deu-lhe o espírito; receberá, pois, de volta este espírito por ocasião da morte dessa criatura. Você, Terra,
} 
verdadeira essência do ser humano. Trata-se de uma fábula sobre a origem da humanidade que, por ter se constituído pelo cuidado, tornou-o um modo-de-ser fundamental do homem e da mulher.

O cuidado como modo-de-ser concretiza-se em diferentes instâncias, dentre as quais citamos: o cuidado do planeta; cuidado do outro; dos pobres oprimidos e excluídos; do nosso próprio corpo e nossa própria saúde (Boff, 2011).

Entretanto, o cuidado não é assumido por todos de maneira unívoca; há os que o assumem de forma equilibrada e outros que o assumem de maneira patológica. Boff (2011) identifica três preocupantes patologias do cuidado: 1- a negação do cuidado essencial; 2- o cuidado em seu excesso: a obsessão; e 3- o cuidado em sua carência: o descuido.

Para Boff (2011), a negação do cuidado resulta em um processo de desumanização e embrutecimento das relações; nesse caso, o ser humano se entrega ao mau trato das pessoas, da casa, da coisa pública e de si mesmo. Já o cuidado em seu excesso significa que a pessoa torna-se obsessiva para cuidar de tudo e dos outros, e isso é patológico porque o ser humano não pode ser só sua essência; o excesso de cuidado paralisa e prejudica a espontaneidade de quem o recebe. Por outro lado, o cuidado em sua carência também é patológico, pois não é saudável deixar as pessoas e coisas mal cuidadas. Desta forma, o cuidado ideal é o ponto de equilíbrio entre a obsessão e o descuido; é o cuidado que não convive nem com o excesso e nem com a carência.

Tomando como base as reflexões de Boff (2011), pode-se afirmar que o cuidado sempre existiu na relação entre os seres humanos, mas que está sendo ameaçado pela atual tendência ao individualismo e falta de solidariedade.

Nesta nossa investigação, não daremos enfoque à dimensão macro do cuidado, que se refere ao cuidado do planeta, do nicho ecológico e da sociedade sustentável. Nosso foco será na dimensão micro, relacionada ao cuidado entre os seres humanos. Esse recorte justifica-se pelo fato de que o norte da nossa pesquisa é o cuidado de pessoas com deficiência. Os cuidadores de pessoas nessa condição, sejam familiares ou profissionais, podem incorrer no risco de assumirem o cuidado em excesso ou em carência, citado por Boff (2011). Entretanto, também

deu-lhe o Corpo; receberá, portanto, também de volta o seu corpo quando essa criatura morrer. Mas como você, Cuidado, foi quem, por primeiro, moldou a criatura, ficará sob seus cuidados enquanto ela viver. E uma vez que entre vocês há acalorada discussão acerca do nome, decido eu: esta criatura será chamada Homem, isto é, feita de húmus, que significa terra fértil'." 
podem assumir um ponto de equilíbrio entre essas duas formas de cuidado, com maiores possibilidades de contribuir para o desenvolvimento da pessoa com deficiência e para a saúde emocional e $\operatorname{social}^{24}$ de toda a sua família.

\section{2 \\ Aspectos Formal e Informal da Atividade de Cuidar}

Tronto (1997) considera que a obrigação de cuidar dos outros tem significado moral na sociedade e, para defender essa argumentação, identifica três aspectos morais diretamente relacionados à atividade de cuidar. São eles: capacidade de atenção; autoridade e autonomia; e particularismo.

Segundo o autor, a capacidade de atenção é um aspecto moral, porque na ação de cuidar, o importante não é tratar uma pessoa como entendemos que qualquer indivíduo abstrato gostaria de ser tratado, mas tratar o indivíduo do cuidado da maneira como ele desejar, considerando suas necessidades específicas e concretas. Para cuidar, é preciso conhecer as necessidades alheias, já que o cuidado fundamenta-se no conhecimento peculiar da pessoa que está sendo cuidada. Sendo assim, parte importante do processo é a capacidade de atenção às necessidades do outro. Porém o autor esclarece que a capacidade de perceber as necessidades do outro não é simples. Ele exemplifica que muitos pais agem menos para atender às necessidades dos filhos e mais para solucionar necessidades que eles próprios carregam desde a infância. É necessário um "autoconhecimento extraordinário, a fim de que a pessoa que cuida não transforme simplesmente as necessidades do outro numa projeção das próprias necessidades.” (Tronto, 1997, 192). Assim, a atenção ao outro suscita uma questão moral, porque exige a abnegação de si mesmo para que se possa perceber claramente os interesses do outro. Essa atenção demanda um esforço e uma disponibilidade de tempo, que pode custar um alto preço para o cuidador. Além disso, abnegar-se em função do outro, renunciando às suas próprias necessidades, resulta em uma forte ligação do cuidador com o sujeito cuidado. Isso pode

\footnotetext{
${ }^{24}$ A Organização Mundial de Saúde (OMS) define saúde não apenas como a ausência de doença, mas como a situação de perfeito bem-estar físico, mental e social. (FERRAZ, 1997).
} 
constituir-se em um problema, pois a perda do sujeito cuidado pode resultar na destruição de quem efetuava a atividade de cuidar (Tronto, 1997).

Outros aspectos morais destacados pelo autor quando se fala da ação de cuidar são a autoridade e autonomia. A pessoa que cuida pode incorrer no risco de desejar manter a pessoa cuidada dependente, assumindo uma postura autoritária. O respeito à autonomia é uma questão que precisa ser lidada todo o tempo nas relações entre as pessoas que cuidam e as que dependem do cuidado.

O terceiro e último aspecto é o particularismo. A decisão sobre a quantidade de cuidado que deve ser proporcionada não pode ser universalizada, mas compreendida de acordo com os desejos e necessidades da pessoa que necessita do cuidado (Tronto, 1997).

Esses aspectos do cuidado exercido entre os seres humanos podem ser percebidos em atividades profissionais - cuidado formal - ou por desvelo e solidariedade - cuidado informal. O primeiro é prestado por instituições lucrativas, não lucrativas e públicas, tendo especial destaque aquelas vinculadas às áreas da saúde. Por esse motivo, é um tema bastante referenciado nas produções acadêmicas desses espaços de intervenção; fundamentalmente nas publicações da enfermagem. Já o cuidado informal, é prestado dentro do grupo familiar e, também, por vizinhos, amigos e voluntários (Carvalho, 2007).

Embora seja o cuidado familiar (informal) que está diretamente relacionado ao objeto da nossa investigação, consideramos relevante aprofundarmos a compreensão acerca do cuidado formal, uma vez que muitas famílias consideramse incapazes de cuidar de seus filhos com deficiência, atribuindo tal competência a instituições ou profissionais de saúde (Cavalcante, 2003). Esse pensamento tem contribuído para motivar famílias a permitirem que pessoas com deficiência permaneçam o máximo de tempo possível em instituições terapêuticas especializadas $^{25}$.

A decisão de mantê-las nessas instituições por período integral, além de refletir no poder aquisitivo da família, devido ao custo elevado, pode ser responsável por 'traumatizar' as pessoas com deficiência, principalmente por

\footnotetext{
${ }^{25}$ A discussão sobre percepções de capacidade ou incapacidade familiar para o cuidado dos filhos remete-nos a pensar o papel do Estado, no que se refere à garantia de sustentabilidade das famílias para que elas possam prevenir, proteger, promover e incluir seus membros (BRASIL, 2004), conforme abordado na seção 1.2 .
} 
causa do modo fragmentado com que os sujeitos com muitos déficits costumam ser tratados pelos diversos profissionais que os atendem (Cavalcante, 2003).

Essa visão de incapacidade das famílias para o cuidado de pessoas com deficiência é, muitas vezes, compartilhada por outros setores da sociedade, dentre os quais destacamos os profissionais de saúde e os representantes do Estado. Como ressalta Rizzini (2010), um dos motivos fundamentais para os abrigamentos de crianças e adolescentes com deficiência e para a sua permanência nos abrigos púbicos é a gravidade/particularidade do quadro da criança e do adolescente, em questão, associado ao sentimento de incapacidade da família em prover o tratamento necessário. Para a autora, isso demonstra que as famílias são percebidas (inclusive por elas mesmas) como incapazes de prover os cuidados necessários e, por isso, são punidas com a retirada das crianças e adolescentes com deficiência da sua convivência.

Nesse sentido, o aspecto formal do cuidado pode fazer parte de um contexto que compromete ou até exclui o cuidado familiar. Pode também acontecer de os receptores do cuidado serem desrespeitados em seus desejos e opiniões, tais como a vontade de estar com sua família. Essa última possibilidade, o desrespeito aos desejos dos sujeitos cuidados, ocorre com pessoas com deficiência (Oliveira, 2010) e com demais grupos que apresentam alta dependência de cuidados; tais como as crianças (Rizzini et al., 2007) ${ }^{26}$.

Para que os receptores de cuidado possam ser respeitados em seus desejos, há produções teóricas (Luz \& Miranda, 2010) que defendem a importância do investimento num cuidar ético, que não se limita ao conhecimento técnico, mas ao respeito pelas necessidades dos clientes. Outras publicações sobre o cuidado em saúde (Wetzel et al, 2009; Ortiz et al., 2011; Silva, et al. 2009) buscam favorecer o despertar dos profissionais da área para a valorização do cuidado familiar.

$\mathrm{Na}$ advocacia pelo cuidado ético, Luz \& Miranda (2010) incentivam a valorização dos desejos das pessoas cuidadas, sem discriminá-las. Tomando pacientes soropositivos como sujeitos da sua investigação, as autoras defendem que o cuidado ético deve ser viabilizado por meio da concessão de respeito e atenção, que muitas vezes é negado a esse grupo no ambiente da família e do trabalho. Esse cuidado deve ser expandido à saúde dos parceiros dos portadores

\footnotetext{
26 Segundo Rizzini et al. (2007), apesar dos avanços nas legislações, no dia a dia, as oportunidades e os mecanismos de participação das crianças continuam limitados.
} 
do HIV/AIDS; neste caso, o cuidar com ética está vinculado à importância de convocá-los, com bastante destreza e delicadeza, a fim de que possam procurar assistência institucional para investigação de sua condição sorológica. Sendo assim, o cuidar ético não se limita ao domínio técnico, mas às necessidades do cliente, sem julgá-lo, discriminá-lo ou estigmatizá-lo.

Entendemos que o cuidado ético deve ser incentivado nos mais diversos campos de atuação dos profissionais da saúde, fundamentalmente nas áreas da psiquiatria e deficiência, pelo arraigado e histórico estigma de incapacidade de decisão que esses grupos vivenciam (Goffman, 2008; Foucault, 2010a).

No que se refere ao cuidado em psiquiatria, Cardoso \& Galera (2011) relembram que o tratamento da loucura foi historicamente baseado na intolerância frente ao comportamento dos doentes mentais, tendo o cárcere como solução para marginalizá-los; com a justificativa de proteção da sociedade. Convém recordar que as pessoas com deficiência foram submetidas ao mesmo tratamento estigmatizante dos doentes mentais. No século XIX, aos deficientes foram atribuídas imagens de anormalidade e periculosidade, tornando-os alvo de medidas de correção e adestramento, e mantendo-os à margem da sociedade (Foucault, 2010a). Construiu-se uma rede institucional complexa, que serviu ao mesmo tempo de estrutura de 'acolhimento' para os anormais e de instrumento de 'defesa' da sociedade (Foucault, 1997). As práticas de intervenção terapêuticas, desenvolvidas nas instituições daquele período, visavam operar efeitos de normalização nos indivíduos, por meio do poder de disciplinarização de seus corpos (Foucault, 2010b).

Ao contrário dos antigos métodos de tratamento destinados às pessoas com deficiência e pacientes psiquiátricos, as novas políticas de saúde acenam para uma assistência que atue nas perspectivas de inclusão e respeito a esses segmentos sociais.

Santos (2009) relembra que as novas políticas de Saúde Mental, construídas a partir da Reforma Psiquiátrica ${ }^{27}$, incitam um movimento de estímulo às mudanças no modo de cuidar dos pacientes psiquiátricos pelos profissionais de

\footnotetext{
27 "A Reforma Psiquiátrica é um processo de reflexão e transformação nos diferentes níveis assistenciais, culturais, políticos, econômicos e conceituais, que por mais de dez anos vem num crescente movimento de desmistificar o estigma da doença mental e, principalmente, garantir o direito da cidadania a essas pessoas para que possam viver melhor no mundo." (SANTOS, 2009, p. 52).
} 
enfermagem e demais membros que compõem a equipe multidisciplinar. Essas mudanças significam o restabelecimento da relação com o paciente psiquiátrico como sujeito ativo, o que pressupõe o rompimento de preconceitos e estigmas, "dando-lhes direitos e capacidade da palavra, diluindo a relação de poder e transformando o modo de viver, cuidando desse ser humano em sofrimento mental, ajudando-o a viver de uma maneira mais digna.” (p. 53). Essa forma de cuidado ético é tratada pela autora como humanístico e a sua antítese é nomeada de cuidado burocrático (Santos, 2009).

O cuidado profissional ético na área da deficiência também pressupõe o rompimento com o histórico estigma atribuído às pessoas com deficiência: o de incapacidade de se expressar, fazer escolhas e, portanto, de exercer sua cidadania (Oliveira, 2010). Além disso, como afirmam Machado \& Scramin (2002), há a necessidade de melhorar a qualificação de profissionais da saúde para o melhor cuidado à pessoa com deficiência, uma vez que há grande despreparo para o atendimento às necessidades específicas deste segmento social.

Corroborando essa discussão, Martines \& Machado (2010) alertam para a necessidade urgente de os profissionais da saúde abrirem passagem às características e desejos singulares dos sujeitos cuidados, que se originam do contexto social, político, cultural, ambiental, biológico e afetivo de cada um. Por esse motivo, não há como haver uma única direção no exercício do cuidado. Ainda segundo as autoras, o cuidado profissional tem de fluir nas perspectivas da aproximação e diálogo, e adquire a finalidade de (re)construir a felicidade dos sujeitos do cuidado. Dessa forma, não há como utilizar critérios de regularidade, pois cada um é feliz em circunstâncias particulares. Dialogar, portanto, é fundamental para esse projeto de cuidado que transita pela felicidade. Com o diálogo torna-se possível o respeito aos desejos do sujeito cuidado, uma vez que viabiliza que o profissional e o usuário do serviço encontrem-se, reconheçam-se e escutem um ao outro. Entretanto, representa um desafio para o profissional, pois significa ter disposição para chamar para a cena lógica "pontos de vista diferentes, que se agregam, se chocam, se fundem e se complementam, interesses, necessidades, saberes, códigos culturais, rituais institucionais, ingredientes científicos e outros do campo social” (Martines \& Machado, 2010, p. 331).

Como abordado anteriormente, além do cuidado profissional (formal), o cuidado também pode ser exercido de maneira informal, justificado pelo desvelo 
ou pela solidariedade e motivado por preocupação e inquietude. Essa segunda forma de cuidado é, fundamentalmente, assumida pelas famílias.

As famílias são socialmente consideradas as principais responsáveis pelo cuidado dos seus integrantes. Segundo Stamm \& Mioto (2003), as categorias família e cuidado estão intrinsecamente relacionadas, uma vez que em toda a sua história, a família foi caracterizada pelo papel de cuidado e proteção de seus membros. Entretanto, apenas recentemente as políticas públicas e as áreas de saúde passaram a percebê-las e valorizá-las como capazes de exercer um importante papel no cuidado em saúde, atuando nos tratamentos de pessoas em situação de doença ou deficiência, influenciando positivamente os resultados da terapêutica, bem como contribuindo para melhor qualidade de vida destas pessoas.

$\mathrm{Na}$ defesa do cuidado familiar, Wetzel et al. (2009) recordam que os Centros de Atenção Psicossocial (CAPS) foram instituídos no Brasil - no contexto da redemocratização e da reestruturação do sistema nacional de saúde tendo como um dos principais objetivos valorizar o papel das famílias no cuidado em saúde, incentivando-as à participação no cotidiano dos serviços. As famílias podem envolver-se diretamente tanto nas atividades do serviço quanto nos trabalhos e ações comunitárias de integração social. "Os familiares são considerados pelos CAPS como parceiros no tratamento." (Wetzel et a., 2009, p. 44).

Nessa perspectiva de reconhecimento da importância das famílias na dimensão do tratamento, profissionais de saúde estão sendo motivados a prover suporte às famílias e integrá-las nos projetos terapêuticos. Há, inclusive, um movimento crescente em defesa da aceitação dos benefícios de manter as pessoas doentes em seu âmbito familiar, o que acelera a necessidade de que os profissionais de saúde transfiram os conhecimentos necessários ao cuidador e ao próprio receptor do cuidado (Ortiz et al., 2011).

Com a Reforma Psiquiátrica, a institucionalização deixa de constituir a base do sistema assistencial em psiquiatria, cedendo terreno a uma rede de serviços extra-hospitalares. Nesse contexto, as famílias têm se tornado, cada vez mais, os principais provedores de cuidado em saúde mental, juntamente com o próprio paciente e os profissionais dos serviços comunitários (Cardoso \& Galera, 2011). O movimento de desinstitucionalização abrange também as pessoas com 
deficiência, incentivando que permaneçam incluídas socialmente, assegurando o direito ao convívio familiar e comunitário ${ }^{28}$.

Conforme afirmam Stamm \& Mioto (2003), existem situações em que as famílias necessitam do cuidado profissional para que possam exercer o melhor cuidado. Cabe então aos profissionais fortalecer as famílias, apoiá-las e orientá-las quando as encontrarem fragilizadas, bem como incentivá-las na promoção da saúde familial (Stamm \& Mioto, 2003). Desta forma, como ressaltam Elsen et al. (2009), tornam-se emergentes alguns aspectos: a preparação específica de profissionais para atuarem com famílias; a adequação das instituições de saúde para acolher e cuidar de famílias; e planos e ações que facilitem às famílias o fácil acesso aos serviços de saúde sempre que deles necessitarem.

Um entrave para a garantia desses aspectos é a tendência de muitos profissionais de estereotipar as famílias, naturalizando-as num modelo de como ser mãe, como ser pai e como ser filho (Mioto, 1998). Stamm \& Mioto (2003) defendem a importância de que os profissionais tenham em mente, que o cuidado familial vai ocorrer a partir do mundo de significados de cada família e do desenvolvimento ao longo do seu viver, o que dá a cada uma delas um caráter de especificidade.

Dessa forma, os profissionais de saúde devem lembrar que as famílias têm discernimento para determinar padrões de interação, optar e reorganizar seu ambiente (Stamm \& Mioto, 2003). Concordamos com as autoras que as famílias devem ser respeitadas pelos profissionais em seus modelos relacionais, mas desde que o padrão escolhido não viole os direitos humanos do sujeito receptor do cuidado.

$\mathrm{Na}$ contramão da valorização do papel da família como cuidadora, algumas mudanças na sociedade contemporânea têm trazido novos desafios para o cuidado exercido no espaço do lar. Dentre essas mudanças, Ortiz et al. (2011) citam como fundamentais: 1- a queda na taxa de natalidade, que gera a diminuição do tamanho da população e das famílias; tal queda, em última instância, significa a redução do número de cuidadores no âmbito familiar. 2- o envelhecimento da população

\footnotetext{
28 Vale reiterar que, na prática, a institucionalização em abrigos de pessoas com deficiências graves continua sendo uma realidade (RIZZINI, 2010).
} 
mundial, trazendo o incremento do fenômeno da dependência, por meio da cronicidade e da deficiência, o que complexifica as necessidades de cuidado.

Sendo assim, os desafios incluem a necessidade constante de inovações e adaptações das famílias para esta nova realidade, caracterizada pela redução do número de cuidadores nas famílias, associado à complexificação das necessidades de cuidados. Esses desafios são acentuados em decorrência da generalização das atividades femininas remuneradas, e a consequente redução do tempo das mulheres para o exercício do papel de cuidadoras, historicamente atribuído a elas (Ortiz et al., 2011; Carvalho, 2007; Wetzel, 2009).

\section{3 \\ Cuidados de Pessoas com Deficiência e suas Implicações para as Famílias}

De acordo com o tradicional roteiro da divisão dos gêneros descrito por Tronto (1997), "os homens se preocupam com o dinheiro, carreira, ideias e progresso; mostram-se preocupados com o trabalho que realizam, os valores que têm e o sustento de suas famílias." (p. 1). Assim, eles ocupam-se com o "cuidado com'. Já as mulheres, “cuidam de suas famílias, vizinhos e amigos; e o fazem ao realizar o trabalho direto de cuidar." (p. 1). Dessa forma, elas ocupam-se com o 'cuidado de'.

Considerando a proposição do autor de que esse roteiro permanece como modelo de conduta a ser adotado por homens e mulheres em nossa sociedade (Tronto, 1997), refletiremos, a seguir, a respeito das responsabilidades assumidas por pais e mães quanto ao específico ‘cuidado de' filhos com deficiência. 


\subsection{1 Identificação do Cuidador de Pessoas com Deficiência no Âmbito Familiar}

Rizzini \& Menezes (2010), em suas pesquisas sobre a temática da deficiência, informam resultados sobre cuidado e cuidadores obtidos em outros estudos. Assim, Araújo (2002, Apud Rizzini \& Menezes, 2010) comparou as atitudes dos pais com as das mães em relação ao filho com deficiência e observou que os pais apresentam dificuldade na exposição dos sentimentos, e têm mais controle da situação, mais equilíbrio e tomam atitudes mais racionais. Eles parecem trazer internalizado o modelo dominante de família, determinante de que mães devem ser responsáveis pelo cuidado dos filhos e, os pais, pela provisão material. Em consonância com Araújo (2012), Souza \& Boemer (2003, Apud Rizzini \& Menezes, 2010) relatam que os pais mostraram-se participantes no cuidado, embora com atitudes ainda permeadas por concepções de que essa responsabilidade caberia à mãe. Também Yano (2003, Apud Rizzini \& Menezes, 2010) apontou que apesar dos pais relatarem alguma participação nos cuidados e educação da criança, ainda acreditam que a sua principal função é prover a família.

Silva (2000) e Silva (2007), em seus estudos sobre famílias de pessoas com deficiência mental, chegam a conclusões semelhantes. Segundo as autoras, as mães exercem o papel principal pelas tarefas domésticas, pelos cuidados e pela transmissão de regras às crianças com deficiência mental; o pai divide os cuidados da criança, porém com uma frequência menor, exercendo, assim, um papel secundário. Na pesquisa de Bastos \& Deslandes (2008) sobre a experiência de ter um filho com deficiência mental, as autoras também percebem que, excepcionalmente, destaca-se o papel do marido para além de prover o sustento.

Corroborando esses resultados, Almeida (2011), em seu estudo sobre cuidado de pessoas com deficiência a partir de famílias de camadas médias, revela que mesmo em famílias da classe média, com alto nível de escolaridade, com mulheres economicamente ativas e que participam do provento do lar, há a manutenção de um padrão tradicional de divisão de tarefas no lar. Essa tradição se revela porque, embora os homens tenham passado a executar algumas atividades de cuidado, a organização e administração dessas atividades são realizadas 
essencialmente pelas mulheres. Elas também reforçam a concepção tradicional de que o amor materno é incondicional e abnegado, e de que a feminilidade é afirmada por esse amor.

A literatura específica sobre cuidado na área da deficiência afirma, portanto, que as mulheres são as principais cuidadoras dos filhos com deficiência, o que vai ao encontro da discussão de que a mulher é a principal responsável pelos cuidados no âmbito privado. Entretanto, convém destacar a presença dos homens no cuidado dos filhos com deficiência, ainda que de forma secundária e mantendo a tradicional concepção de que essa não é sua principal tarefa.

Pressupomos que a divisão de papéis de gênero traz implicações para todos os membros da família de uma pessoa com deficiência, que apresente múltiplos comprometimentos, sobretudo pela prolongada demanda de cuidado, exigida pela sua condição. Isto começa a expressar-se ou tornar-se visível a partir da constatação da deficiência, e em função dos sentidos a ela atribuídos pelas famílias.

\subsection{2 \\ A Constatação da Deficiência do(a) Filho(a) e Seus Significados para as Famílias}

É com base na literatura corrente, que se pode afirmar que a descoberta da deficiência de um filho representa um 'divisor de águas' entre o antes e o depois desse acontecimento, visto que esse fato exigirá da família adaptações e mudanças na sua organização interna.

Silva \& Dessen (2001), ao abordar a família como contexto de desenvolvimento para a criança com deficiência mental, discorrem sobre o intenso impacto da chegada de uma criança com algum tipo de deficiência. Segundo as autoras, o momento inicial é o mais difícil para a família; frequentemente, são comuns sentimentos de choque, negação, raiva, revolta e outros, até que busquem uma organização interna e construam um ambiente familiar mais preparado para incluir a criança. 
$\mathrm{Na}$ busca de conhecer a reação dos pais à descoberta deficiência, Petean \& Neto (1998) afirmam que o processo de sofrimento dos pais e mães, ao receber a notícia, é agudo; passando por um período de enlutamento pela perda do filho esperado.

Com relação ao impacto do diagnóstico na dinâmica familiar, Petean \& Murata (2000) concluem que:

O impacto é tão grande que compromete o estabelecimento de vínculo, a aceitação do filho, a compreensão de informações, e perceber-se-á alterações na rotina diária, nos sonhos e projetos de cada membro da família (...) sendo necessário longo processo para que retome o equilíbrio. (p. 41).

Sprovieri \& Junior (2001), que pesquisaram acerca da dinâmica familiar de crianças autistas, também revelam o sofrimento da família com o diagnóstico; nesse caso, justificado pela perda dos projetos de vida. Esse sentimento dificulta a interação entre os seus integrantes.

Góes (2004) avalia que a constatação da deficiência mental de uma criança se apresenta como um transtorno psicológico importante para a família. A esse respeito, o autor citou uma pesquisa internacional (americana) sobre afetos vivenciados por mães, de cujos filhos nasceram com Síndrome de Down: culpa, negação, inferioridade, vergonha, desejo de morrer, raiva, necessidade de culpar terceiros e solidão. Corroborando o enlutamento descrito por Petean \& Neto (1998), o autor destacou o sentimento de morte (perda) do filho idealizado - o filho perfeito. Ele verificou que surge, nos pais, o estranhamento com relação ao filho real, pelo fato de lhes serem ativadas as mais diversas representações sociais sobre a deficiência mental, as quais já habitavam as suas cadeias associativas; tais representações são, geralmente, negativas. Ainda segundo o autor, os afetos e comportamentos mais comuns dos pais e mães, ligados às suas representações, são: o desejo de morte, o sentimento de culpa, o sentimento de inferioridade, o desejo de reparação da deficiência mental do filho e a denegação. Descreveremos, a seguir, um breve resumo sobre cada um desses afetos citados pelo autor.

- Desejo de morte: a confirmação da deficiência mental do filho gera nos pais, ainda que inconscientemente, o desejo de morrer ou de que a criança morra; 
- Sentimento de culpa: pais culpabilizam-se por serem os agentes responsáveis pela transmissão de um legado defeituoso, e sentem-se culpados pelo desejo inconsciente (às vezes consciente) de morte da criança.

- Sentimento de inferioridade: relacionado à vergonha por não ter gerado o filho idealizado.

- Desejo de reparação: desejo de corrigir ‘aquilo que não funciona bem' no filho. Trata-se do desejo de tornar o filho uma pessoa sem deficiência, portanto, impossível de ser realizado.

- Denegação: compreendida como um mecanismo de defesa. Trata-se de "um processo pelo qual o sujeito, embora formulando um dos seus desejos, pensamentos ou sentimentos até então recalcado, continua a defender-se dele, negando que lhe pertença" (Góes, 2006, p. 456). A denegação da deficiência do filho foi observada pelo autor em todas as entrevistas por ele realizadas, quer seja consciente ou inconscientemente.

Tomando como base a literatura acima sintetizada, podemos constatar que a descoberta da deficiência de um filho é alarmante; causa sofrimento e mais uma série de implicações emocionais para as famílias. Passado o choque provocado pela notícia, as famílias vão reorganizando-se internamente e adaptando-se à nova realidade, o que significa que a deficiência do(a) filho(a) implica vicissitudes nas dinâmicas familiares.

\subsection{3}

\section{Processos de (Re)organização nas Dinâmicas Familiares $e$ as Implicações para as Famílias}

Petean \& Murata (2000), ao investigar famílias de filhos com paralisia cerebral, concluem que a presença da criança com deficiência, por si só, modifica a dinâmica familiar. O tipo de modificação provocada e a intensidade da mesma dependem da gravidade da deficiência e do significado que essa tem para cada família.

Embora o momento da descoberta esteja associado aos sentimentos de dor, desespero e raiva, segundo Silva \& Dessen (2001), após algum tempo, o sentido 
da deficiência de um filho tende a ser ressignificado. Uma forma de ressignificação, que pode impossibilitar a construção de uma dinâmica familiar acolhedora do filho, é a negação da sua deficiência, associada à fantasia do filho idealizado. De acordo com Cavalcante (2007), a consequência da negação pode ser o empecilho para ajudar o filho, seja porque a família fica paralisada ou porque canaliza suas ações na busca de uma cura milagrosa. É justamente a aceitação da condição do filho, que poderá fazer a família descobrir forças insuspeitadas para enfrentar a situação, encontrando um tipo de postura e atitude que, de fato, poderá ajudá-lo.

Dessa forma, é reconhecendo os limites e potencialidades dos filhos que a família vai ao encontro de diferentes e necessárias formas de ajuda na sociedade, na comunidade, na saúde, na educação, entre amigos, parentes e outros.

Se a família se fechar, se isolar e não inserir o filho em apoios continuados, de diversos tipos, a deficiência será um fardo para todos, o desenvolvimento psíquico e social do filho ficará prejudicado. Se a família se abrir para compreender a incapacidade e tentar reduzir as desvantagens, através de formas de ajuda que atendem a necessidades específicas, então a deficiência poderá tornar-se um 'trampolim' para muitas aprendizagens e diferentes formas de superação para todos (Cavalcante, 2007, p.187).

As implicações dos processos de (re)organização familiar, em termos de cuidado, podem ser, portanto, prejudiciais para a pessoa com deficiência, se a família negar a condição do filho e evitar buscar ajudas na sociedade. Porém, se a família for à busca dos recursos da sociedade e reconhecer as possibilidades e limites de desenvolvimento do filho, o cuidado tenderá a ocorrer de forma a contribuir para a sua evolução (Cavalcante, 2007).

Em sua pesquisa, Cavalcante (2003) demonstra que para melhor interferir na evolução global da pessoa com deficiência e caminhar no sentido de uma história de superação, a família terá de: elaborar psíquica e socialmente a deficiência do filho; construir novo estoque de conhecimentos para aprender a compreender esse filho e encontrar meios apropriados para atender às suas necessidades; e terá de contar com o apoio dos familiares, dos amigos, dos profissionais e das políticas públicas. Ajudar um filho com deficiência pressupõe recorrer a múltiplas fontes de apoio: na vida íntima, no interior da família, nos apoios técnicos especializados e na vida social (Cavalcante, 2007). 
Além da pesquisa de Cavalcante (2007), a rede de apoio social ${ }^{29}$ é valorizada em vários outros estudos acerca do cuidado de pessoas com deficiência. Bastos \& Deslandes (2008) relatam a importância desse suporte para que a família possa exercer o cuidado e evitar a solidão, as ameaças econômicas e o desespero. Contar com essa rede e com os serviços disponibilizados para o tratamento do filho com deficiência são aspectos relevantes para a garantia de melhores condições de vida para a pessoa com deficiência e sua família (Sprovieri \& Júnior, 2001).

Barbosa et al. (2009), a partir de seu estudo com mães de crianças com deficiência, revelam haver diferentes tipos de suporte na sociedade, que são acessados pelas famílias de pessoas com deficiência e servem como fator motivador para manutenção de hábitos saudáveis. Há o suporte emocional, caracterizado pela amizade e demonstração de cuidado ou simpatia; esse suporte ajuda a família a sentir-se mais confortada e amparada. Há o suporte de informação, que funciona quando uma pessoa ou instituição é fonte de conhecimento e esclarece à família onde pode conseguir a informação que necessita; esse suporte ajuda a família a compreender o que está acontecendo com o(a) filho(a), e a acessar informações sobre a melhor maneira de cuidar dele(a). Há o suporte material, caracterizado pela provisão e oferecimento de recursos materiais e financeiros, tais como: dinheiro, livros, passagens e outros; esses recursos são fundamentais para que a família consiga atender às demandas de cuidado impostas pela condição do filho. Por fim, há o suporte de avaliação que dá à família um retorno sobre a maneira como está agindo, emitindo sugestões ou fazendo elogios; o que provê realimentação das atitudes dessa família.

Como discutido, a literatura (Cavalcante, 2003; Sprovieri \& Junior, 2001; Barbosa et al., 2009) demonstra que, após a ressignificação da deficiência, há famílias que conseguem construir uma dinâmica acolhedora, criativa e positivada. As famílias podem, portanto, proporcionar à pessoa com deficiência um ambiente

\footnotetext{
${ }^{29}$ Rede de apoio social, também nomeada de rede de suporte social, é composta de amigos, vizinhos, companheiros de igreja e familiares. Essa rede oferece apoio emocional e suporte financeiro, constituindo lógicas de atenção que se distinguem do mercado ou da regulação do Estado e que facilitam o enfrentamento dos problemas e contribuem para o bem-estar geral (BASTOS \& DESLANDES, 2008).
} 
facilitador $^{30}$ do seu desenvolvimento e uma dinâmica favorecedora da saúde de todos os integrantes do sistema familiar.

Sprovieri \& Junior (2001) identificam os seguintes itens positivos em dinâmicas familiares, que foram reorganizadas após a constatação da deficiência de um filho: a melhoria na comunicação entre os membros da família; a união; e a ampliação da afeição física. Segundo os autores, tais itens são considerados positivos por trazerem consequências benéficas para toda a família.

Entretanto, Sprovieri \& Junior (2001) identificaram itens negativos em outras famílias; tais como: a dificuldade na promoção da saúde emocional dos membros do grupo; estresse dos pais; dificuldade na interação conjugal; prejuízos na interação social, uma vez que a família sofre pressão social, quando tem um elemento que não corresponde às expectativas sociais e, por isso, apresenta maiores dificuldades relacionais; e baixa autoestima dos pais, pois um filho com deficiência desvaloriza a família perante a sociedade. Esse estudo também identificou que algumas famílias passam a viver em função do filho, por sua dificuldade de adquirir autonomia e pela sua dependência permanente.

Alguns autores (Simeonsson \& McHale, 1981; Lobato, 1983; Soares, 2005) direcionaram o olhar investigativo para as implicações da deficiência para a vida dos irmãos.

Lobato (1983) verificou que os irmãos de crianças com deficiência, quando comparados aos seus pares, apresentam maior risco de se estressarem e sofrerem problemas psicológicos, possivelmente pela sobrecarga de responsabilidades atribuídas a eles e pela menor atenção recebida dos pais. Entretanto, Lobato (1983) também identificou benefícios obtidos pelos irmãos de pessoas com deficiência, como uma maior compreensão das pessoas em geral, maior sensibilidade e valorização da própria saúde e inteligência.

Soares (2005) constatou, em sua pesquisa, que quando as crianças assumem o papel de cuidadores dos irmãos com deficiência, ficam com uma sobrecarga de responsabilidades, o que as força a amadurecer precocemente. Já Simeonsson \& McHale (1981) revelam que o maior tempo exigido e gasto pelos pais com a

\footnotetext{
${ }^{30}$ Ambiente facilitador é um conceito advindo da Teoria Winnicottiana, segundo a qual cabe à família a função de prover um ambiente adequado para um processo bem sucedido de desenvolvimento dos filhos. Um ambiente facilitador faz-se necessário para que a criança possa estabelecer um sentimento de confiabilidade em si mesmo, tendo condições de relacionar-se com o mundo (OLIVEIRA \& AMERICANO, 2005).
} 
criança com deficiência gera ressentimentos nos irmãos 'normais', que subordinam suas necessidades às do irmão deficiente. Além disso, os pais cobram responsabilidades de cuidado e esperam mais das crianças 'normais', sem, no entanto, conseguirem dar a elas o mesmo tempo e a mesma atenção dispensada ao filho com deficiência. Ainda segundo Simeonsson \& McHale (1981), de acordo com as considerações dos pais, os filhos sem deficiência são mais eficientes que eles próprios no cuidado do irmão com deficiência, por serem mais espontâneos e entusiasmados nas interações e nos contextos das brincadeiras e por deterem-se no objetivo de adaptá-lo.

No que se refere às implicações da deficiência do(a) filho(a) para as mães, a literatura (Bastos \& Deslandes, 2008; Almeida, 2001) demonstra que elas carregam a culpa pela deficiência do filho; constroem uma autoavaliação 'heroica', relatando não medirem esforços para dar o melhor ao filho; e sobrecarregam-se com o cuidado dele. Dessa forma, pode-se afirmar que as implicações de ter um filho com deficiência podem ser ainda maiores para as mães, uma vez que culturalmente compete a elas o cuidado da prole (Bastos \& Deslandes, 2008).

Barbosa et al (2009) também afirmam que o cotidiano das famílias, em especial das mães, é modificado pelo tempo dedicado ao filho com deficiência. As autoras constatam que, em geral, as mães tomam para si a maior carga de responsabilidade na criação da prole, ocorrendo uma relação de dependência mútua entre mães e filhos.

Almeida (2011) contribui com essa discussão ao constatar, em sua pesquisa, que a atividade de cuidado sobrecarrega e compromete a individualidade do cuidador. Esse, muitas vezes, abre mão de projetos individuais anteriores. A autora verificou que as mulheres, por serem as principais cuidadoras, são as que mais modificam planos individuais. Com a chegada de um filho, sobretudo um com deficiência, elas mudam de profissão, deixam de trabalhar ou diminuem a carga horária de trabalho.

Inferimos que a opção das mulheres por exercerem exclusivamente as atividades domésticas não remuneradas, ou por diminuírem a carga de trabalho para dedicarem-se ao cuidado do(a) filho(a) com deficiência, reflete no orçamento familiar; além de possibilitar maior dependência na sua relação com o parceiro, como discutido no primeiro capítulo. 
Inferimos, ainda, que nos casos de separação de pais de filhos com deficiência, acentuam-se as dificuldades para as mulheres, pois precisarão prover cuidados e atenção por período mais prolongado - dependendo do nível de comprometimento, por toda a vida do filho - e ainda assumir a chefia do lar. Importante ressaltar o fato de que essa chefia feminina pode acarretar dificuldades financeiras para a família, pois os índices de pobreza continuam maiores em lares chefiados por mulheres (Arriagada, 2006), uma vez que elas ocupam posições menos privilegiadas que os homens no mercado de trabalho (Araujo \& Scalon, 2003); o que também foi discutido no primeiro capítulo desta dissertação.

Constatamos que as referências bibliográficas levantadas abordam sobre as implicações da deficiência para a família como um todo; para as vidas das próprias pessoas com deficiência; e também das suas mães e irmãos. Não identificamos, no entanto, publicações brasileiras que discutem acerca das implicações da deficiência de um filho especificamente para as vidas dos pais/homens. 


\section{3 \\ Constatação da Deficiência do(a) Filho(a) e os Processos de (Re)Organização de Famílias Vinculadas a uma Empresa Brasileira de Grande Porte}

\section{1 \\ Percurso Metodológico: Seleção dos Sujeitos, Acesso ao Campo, Realização da Pesquisa e Análise dos Dados}

No intuito de conhecer os processos de (re)organização das famílias a partir da constatação da deficiência do(a) filho(a), em particular no que se refere ao cuidado da prole, buscamos selecionar famílias que receberam o diagnóstico da deficiência há pelo menos cinco anos. Esse critério de tempo justifica-se pelo fato de estarmos interessados em processos, o que exige um percurso temporal minimamente extenso para serem apreendidos.

As famílias selecionadas para sujeitos desta investigação são as que possuem filhos com deficiência inscritos no programa de assistência a pessoas com deficiência da operadora de saúde da empresa brasileira de grande porte; onde a autora trabalha como Assistente Social.

Há um universo de cerca de 400 usuários no programa. Os pais ou mães dessas pessoas com deficiência são empregados, aposentados ou pensionistas da empresa e, no que se refere à renda domiciliar, podem ser classificados como integrantes da classe social média e das classes de elite da população brasileira ${ }^{31}$.

Utilizamos o recurso de entrevista como instrumento para a coleta de dados. Foi entrevistado um membro de cada família selecionada: o pai ou a mãe da pessoa com deficiência. Por tratar-se de uma pesquisa qualitativa, em que a

\footnotetext{
${ }^{31}$ De acordo com o levantamento da Fundação Getúlio Vargas (FVG), os limites das classes sociais são definidos começando pelo que se nomeia de classe E. Esta classe compõe o grupo de miseráveis da população e sua a renda domiciliar total corresponde ao intervalo entre 0 e 768 reais. A classe D possui uma renda mais alta que a dos miseráveis e está compreendida entre 768 reais e 1064 reais de renda domiciliar por mês. Já na classe C, também chamada de classe média, a renda domiciliar está compreendida no intervalo entre 1064 reais e 4591 reais por mês. O grupo de elite, formado pelas classes A e B, é o que supera o limite de 4591 reais, da classe média, em renda domiciliar mensal (FVG, 2012).
} 
quantidade não é o fator predominante ${ }^{32}$, optamos por realizar entrevistas com dois pais e duas mães integrantes de famílias distintas e procuramos um equilíbrio entre os sexos. A motivação para esse corte de gênero justifica-se pelo entendimento de Araujo \& Scalon (2003) de que os homens e mulheres podem assumir diferentes percepções e atitudes sobre a participação masculina e feminina nas esferas privada e pública. As autoras, ao analisarem percepções e atitudes de homens e mulheres sobre a conciliação entre família e trabalho pago no Brasil, puderam identificar tanto opiniões divergentes, quanto pontos de proximidade nas respostas masculinas e femininas. De acordo com elas, sobretudo nos homens, foi verificada a ideia de aceitação do trabalho feminino pago, mas com a conotação de auxiliar; embora de fato não seja um auxílio. A divisão das tarefas domésticas é um item em que as mulheres concordam mais que os homens sobre a necessidade de um maior envolvimento masculino. Especificamente no que se refere ao cuidado dos filhos, há maior consenso entre os sexos, ambos concordando que os homens devem cuidar mais das crianças.

A escolha da abordagem qualitativa justifica-se pelo fato de que esta forma de pesquisa privilegia os sujeitos sociais e trabalha com o universo de significados, motivos, aspirações, crenças, valores e atitudes. Trata-se, portanto, de uma abordagem que nos permite entender as relações e os processos da vida humana, que não podem ser reduzidos à operacionalização de variáveis (Minayo, 2003).

Foi no conceito de relações de consanguinidade, citado por Almeida (1987), que nos repousamos para estabelecer as mães e os pais que seriam convidados para as entrevistas: os que possuíam relações de filiação natural (biológica) com a pessoa com deficiência. Assim, para fins de recorte acadêmico, foram excluídos do critério de seleção mães e pais adotivos ou quaisquer outras pessoas que tivessem assumido a responsabilidade pelos indivíduos com deficiência, formando o que Almeida (1987) nomeia de relações de afinidade.

Além da filiação biológica, a escolha dos entrevistados pautou-se no tipo de deficiência dos seus filhos. Demos enfoque às famílias, cujos filhos com deficiência apresentam mais de um comprometimento no que se refere às

\footnotetext{
${ }^{32}$ Minayo (2003) esclarece que as pesquisas de natureza quantitativas valorizam a mensuração dos dados e apreendem dos fenômenos apenas a região visível (concreta). Já as qualitativas não têm a quantidade como fator predominante, sendo necessária apenas a existência de situações que se repetem para que seja possível a análise dos dados.
} 
habilidades consideradas por Diniz et al. (2007) como básicas para a vida social: mobilidade, uso dos sentidos, comunicação, interação social e cognição. Esse critério justifica-se pela suposição de que a alta dependência de cuidados, muitas vezes vitalício, que uma pessoa com múltiplos comprometimentos demanda (Santos \& Rifiotis, 2006), tende a ser um fator que sobrecarrega a rotina familiar.

Não foi determinado um limite máximo de idade dos filhos com deficiência. Demos, no entanto, prioridade a diferentes faixas etárias, da infância à idade adulta, a fim de que pudéssemos verificar os processos de (re)organização, em termos de cuidado, em diversas fases da vida.

Outro critério adotado, não como regra, mas como preferência para inclusão dos pais e mães na pesquisa, foi a existência de irmão(s) sem deficiência. Pensamos que conhecer o contexto em que esses irmãos inserem-se na dinâmica familiar poderia contribuir para verificarmos se há maior ou menor atenção à pessoa com deficiência, quando comparado aos demais integrantes da família, bem como conhecermos as implicações da deficiência do(a) filho(a) para seu(s) irmão(s).

Priorizamos a escolha de entrevistados que residem na cidade do Rio de Janeiro, por eles serem usuários atendidos pela nossa equipe de Serviço Social e que, portanto, conhecem-nos profissionalmente e têm consolidado conosco uma relação de respeito. Possivelmente essa relação contribuiu para maior confiabilidade na pesquisadora e nos objetivos da investigação ${ }^{33}$. A opção por entrevistados moradores do Rio de Janeiro também se justifica pelo fato de acessarem semelhantes suportes materiais e profissionais disponíveis na rede local.

Em atendimento aos critérios éticos pertinentes, a proposta de estudo foi submetida à aprovação da Câmara de Ética em Pesquisa da PUC-Rio. E para acessar o campo de pesquisa, solicitamos autorização das diversas gerências responsáveis pela operadora de saúde da empresa. Ainda que tenhamos optado por não informar o nome da companhia e do programa nesta dissertação, a autorização dos gestores desses órgãos persistiu constituindo um imperativo ético, uma vez

\footnotetext{
${ }^{33}$ Segundo Minayo (2003), para a entrada no campo, devemos buscar uma aproximação com as pessoas da área selecionada para o estudo. É fundamental consolidarmos uma relação de respeito pelas pessoas que serão sujeitos da investigação. Elas devem ser esclarecidas sobre aquilo que pretendemos investigar, os riscos e as possíveis repercussões favoráveis advindas do processo investigativo.
} 
que a investigação foi desenvolvida com os usuários dos serviços que estavam sob suas responsabilidades.

De posse da autorização da câmera de ética e da empresa, selecionamos duas mães e dois pais que atendiam aos critérios preestabelecidos. Fomos prontamente atendidos, quando os convidamos para participarem das entrevistas.

Visando que as mães e pais selecionados sentissem-se confiantes e confortáveis, solicitamos que eles escolhessem os locais das entrevistas. Três deles - os empregados da empresa - optaram pela sala de atendimento da operadora de saúde; já a pensionista, optou por um local externo.

Pedimos a cada entrevistado que assinasse o Termo de Consentimento Livre e Esclarecido (Apêndice) e informamos nossa disponibilidade para dirimir quaisquer dúvidas a respeito desse documento. Solicitamos permissão para utilizar equipamento de áudio como recurso para a coleta dos dados, e esclarecemos que a gravação poderia ser interrompida e descartada a qualquer momento, se assim eles desejassem.

Antes de iniciar as entrevistas, esclarecemos os objetivos da pesquisa e informamos que o processo investigativo não resultaria em qualquer prejuízo para os entrevistados ou para o(a) seu(sua) filho(a) com deficiência.

Optamos pelo método de entrevista narrativa, por considerá-lo adequado para conhecimento de histórias de vida, incluindo os processos de (re)organização vivenciados pelas famílias ao longo de uma trajetória. A trajetória proposta pela nossa pesquisa inicia-se no período da comprovação da deficiência e vai até os dias atuais.

A entrevista narrativa tem como princípio a coleta de dados a partir da perspectiva do informante. Solicita-se a esse informante que apresente, na forma de uma narrativa improvisada, uma história completa da qual ele tenha participado (Flick, 2009). A entrevista narrativa é iniciada com uma questão gerativa, que serve para estimular a produção de uma narrativa e para manter o foco na área e no período de interesse da pesquisa (Flick, 2009). Desta forma, propusemos a seguinte questão gerativa para a nossa pesquisa: "Por favor, conte-nos como a sua família (re)organizou-se, a partir da constatação da deficiência do(a) seu (sua) filho(a), sobretudo em relação ao cuidado dele(a)."

Flick (2009) ensina-nos, ainda, que no segundo estágio da entrevista narrativa - a fase do questionamento - os fragmentos de narrativa que não ficaram 
claros são reintroduzidos pelo entrevistador, por meio da adoção de outra pergunta geradora de narrativa. Nessa etapa da nossa pesquisa, pedimos que os entrevistados aprofundassem a narração de alguma história por eles iniciada que percebemos estar diretamente relacionada com os objetivos específicos da investigação; tais como: os contextos facilitadores e dificultadores do cuidado e as implicações da deficiência do(a) filho(a) para os integrantes das famílias.

A fase final da entrevista, nomeada de fase de equilíbrio (Flick, 2009), é a que o entrevistador seleciona tópicos abordados anteriormente e faz perguntas mais diretas. Nesta fase, questionamos se a separação do casal guardava relação com a deficiência do(a) filho(a), nos contextos em que o divórcio havia ocorrido; e se o cuidado do(a) filho(a) com deficiência tinha reflexos no orçamento familiar. Também pedimos para os entrevistados narrarem sobre como os outros filhos lidaram com o fato de ter um irmão ou irmã com deficiência, nos casos em que havia mais de um filho na família. Ao longo dessas perguntas, tivemos a cautela de não oferecer pistas sobre o que esperávamos ouvir da narração dos entrevistados, a fim de evitarmos que eles conformassem suas respostas a esses sinais $^{34}$.

Passada a fase da pesquisa de campo, procedemos com as transcrições das entrevistas e realizamos os tratamentos e análises dos dados coletados, tomando como referência o quadro referencial elaborado nos capítulos 1 e 2 .

As análises serão apresentadas em seções subsequentes deste capítulo 3. Nessa etapa, inseriremos fragmentos das narrativas dos entrevistados, a fim de que seja possível ilustrar e dar sentido às nossas argumentações e considerações. Esses fragmentos serão transcritos da exata maneira como foram narrados pelos pais e mães.

Com vistas a tornar os trechos de narrativas mais compreensíveis ao leitor, acrescentaremos comentários entre colchetes. Tais comentários explicarão o assunto que está sento abordado; esclarecerão sobre quem ou o que os entrevistados estão se referindo; e identificarão suas ações.

Utilizaremos outros recursos para facilitar a compreensão das narrativas; tais como: o aumento da entonação da voz - que sinaliza a ênfase dada pelos

\footnotetext{
${ }^{34}$ Becker (1994) alerta aos pesquisadores que utilizam a entrevista como instrumento, que os sujeitos entrevistados poderão conformar suas respostas às pistas que o entrevistador dá do que precisa ser dito ou mostrado. Isso ocorre tanto mais quanto o pesquisador e o seu trabalho forem considerados importantes para os sujeitos entrevistados.
} 
entrevistados a determinadas palavras - será demarcado pelo recurso de caixa alta, de forma a ser possível demonstrar quais termos têm relevância para o narrador; as partes dos trechos que não são fundamentais para ilustrar nossas análises serão excluídas, e esse movimento será demarcado pela inserção de reticências entre parênteses; e os segmentos merecedores de destaque serão sublinhados, e eles serão assim considerados quando demarcarem, mais precisamente, o que objetivamos ilustrar com a apresentação do trecho da narrativa.

Para melhor distinguirmos as famílias participantes desta pesquisa, designamos a elas números de 1 a 4. Em consonância à definição de 'família' que adotamos nesta dissertação ${ }^{35}$, optamos por incluir como membros das quatro famílias pesquisadas as pessoas que possuem laços consanguíneos com a pessoa com deficiência. Assim, estamos considerando o pai e a mãe da pessoa com deficiência como integrantes do mesmo sistema familiar, ainda que eles estejam separados, vivendo em residências distintas e em novas uniões matrimoniais.

Os integrantes das famílias serão nomeados de acordo com o parentesco que possuem com a pessoa com deficiência - pais, mães ou irmãos - e distinguidos pelo número da família a que pertencem. Já as próprias pessoas com deficiência, receberão a nomenclatura de filho(a) e também serão diferenciadas pelo número da família a qual fazem parte. Essas terminologias, substitutivas dos nomes dos integrantes das famílias, serão utilizadas para impedir a identificação dos sujeitos da pesquisa, em atendimento aos critérios éticos pertinentes. Também será mantida a confidencialidade dos nomes de instituições e profissionais citados pelos entrevistados, substituindo-os pelas suas iniciais.

\section{2}

\section{Caracterização das Famílias Sujeitos da Pesquisa}

Apresentamos, aqui, uma breve caracterização das famílias, a fim de que tenhamos as bases mínimas para compreensão das suas histórias e narrativas; que serão descritas e analisadas nas próximas seções. Os dados originam-se dos

\footnotetext{
${ }^{35}$ A definição de Família adotada nesta dissertação consta na seção 1.1.3. (página 30).
} 
arquivos físicos e eletrônicos do programa de assistência a pessoas com deficiência da empresa a que nossos entrevistados estão vinculados, bem como do curso das narrativas de cada um deles.

A Família 1 é composta pela mãe, pelo pai e pela filha com deficiência. Os pais são casados e os três integrantes da família residem na mesma casa. A mãe que nos concedeu a entrevista - tem 35 anos de idade, curso superior completo na área de Engenharia e está vinculada à empresa brasileira de grande porte, na condição de empregada. O pai tem 40 anos, curso superior completo na área de Engenharia e também é empregado da empresa. A filha tem 5 anos e possui diagnóstico de Síndrome de $\operatorname{Rett}^{36}$. Os principais comprometimentos, decorrentes da Síndrome, apresentados pela criança são: comprometimento cognitivo, afasia (deficiência na fala), atraso no desenvolvimento motor, disfunções sensoriais, interação social prejudicada e estereotipias. Os tratamentos realizados até o momento foram: fisioterapia, hidroterapia, terapia ocupacional e psicopedagogia. Ingressou na creche/escola, mas quando a Síndrome instalou-se de forma mais severa, os pais optaram por retirá-la.

A Família 2 é composta pela mãe, pelo pai, pela filha com deficiência e pelo irmão mais velho. A mãe foi quem nos concedeu a entrevista; ela possui 66 anos de idade, nível superior completo na área de biblioteconomia e está vinculada à empresa na condição de pensionista. O pai está falecido, mas antes desse acontecimento, houve o divórcio do casal; ele era Administrador e empregado da empresa. O irmão possui 39 anos e não reside mais com a mãe. A filha com deficiência tem 37 anos, possui Síndrome de Freeman-Sheldon ${ }^{37}$, com déficit cognitivo e seus principais comprometimentos são: déficits nas habilidades de coordenação motora ampla e problemas na comunicação e expressão. Os tratamentos até então realizados foram: psicomotricidade, psicoterapia, fonoaudiologia e musicoterapia. Estuda em uma instituição educacional

\footnotetext{
36 “A Síndrome de Rett é uma condição que afeta de forma quase exclusiva indivíduos do sexo feminino (...). Caracteriza-se por perda de interesse pelo meio, associado à regressão da habilidade de comunicação e pela presença de movimentos estereotipados, especialmente das mãos, que deixam de ser utilizadas com um propósito. Há ainda desaceleração da velocidade de crescimento craniano, alterações da frequência respiratória, com períodos de hiperpneia, intercalados por apneia, bruxismo, escoliose e, com frequência, epilepsia. Nas crianças que mantêm a habilidade de caminhar, observa-se ataxia e apraxia da marcha." (Centro de Estudos do Genoma Humano, 2011). ${ }^{37}$ A Síndrome de Freeman-Sheldon é uma desordem de origem genética, "cuja frequência é rara, bem delineada morfologicamente, caracterizada por um quadro dismórfico, que associa alterações ósseas e contraturas articulares com uma expressão facial típica" (ROCHA \& CARVALHO, 2011).
} 
especializada no atendimento a pessoas com deficiência e está residindo em uma moradia assistida ${ }^{38}$.

A família 3 é formada pela mãe, pai, pelo filho com deficiência e por duas irmãs mais novas. Os pais são casados e todos os integrantes da família residem na mesma casa. A mãe possui 57 anos de idade, nível superior completo na área de educação e não exerce atividade remunerada. O pai - que nos concedeu a entrevista - tem 69 anos, nível superior completo na área de Geologia e está vinculado à empresa na condição de empregado. As irmãs possuem 23 e 26 anos, e são estudantes. O filho com deficiência tem 32 anos e foi diagnosticado com uma Lesão Difusa Cerebral ${ }^{39}$. Os principais comprometimentos que ele apresenta são: hipotonia generalizada com comprometimento motor e na área da fala, atraso cognitivo e alterações na aprendizagem. Os tratamentos realizados até esta data foram: psicomotricidade, fonoaudiologia, musicoterapia, fisioterapia e oficinas terapêuticas. O rapaz estuda em uma instituição educacional especializada no atendimento a pessoas com deficiência e pratica atividades físicas para prevenção da osteoporose.

A família 4 é composta pelo pai, mãe e filho com deficiência. Os pais são separados e possuem a guarda compartilhada do filho. A mãe tem 52 anos, nível superior completo em Serviço Social, e exerce atividade remunerada na sua área de atuação. O pai, que foi o entrevistado, possui 52 anos, nível superior completo na área de direito e vincula-se à empresa na condição de empregado. $\mathrm{O}$ filho com deficiência tem 14 anos e sua principal deficiência é a Disacusia Sensorioneural Bilateral Profunda ${ }^{40}$ (deficiência auditiva). Também possui Transtornos

\footnotetext{
38 "No contexto da Reforma Psiquiátrica, surge a Moradia Assistida, que é um dispositivo residencial, onde moram pessoas com necessidades especiais assistidas por cuidadores. (...) Uma moradia assistida não é uma clínica, nem é local de tratamento. As pessoas que nela moram devem fazer seus tratamentos fora da casa, a fim de promover a inserção na vida comunitária. (...) O que há na moradia assistida é o suporte aos residentes em suas atividades cotidianas, a partir da perspectiva de incentivá-los a tornarem-se progressivamente mais independentes em suas atividades da vida diária, no limite de suas possibilidades." (ALVAREZ \& CARVALHO, 2006).

39 "Usualmente as lesões difusas são decorrentes de agressões que acometem todo o cérebro, como por exemplo, quando há falta de oxigênio ou nutrientes durante a formação da criança ainda no útero da mãe, no parto ou na infância. No entanto, nem todos os casos são relacionados a fatores de agressão. Algumas doenças são devido a alterações celulares determinadas geneticamente. Infelizmente algumas lesões não são vistas nos exames de imagem atuais, e o diagnóstico deve ser feito com base na história, achados de EEG e evolução da doença." (INSTITUTO NEUROLÓGICO DE SÃO PAULO, 2013).

${ }^{40}$ A disacusia expressa um defeito na audição. (...) Nela, as alterações da discriminação auditiva são as responsáveis pela qualidade da audição. As disacusias, portanto, representam deficiências de audição do tipo sensorioneural. (TRATADO DE FONOAUDIOLOGIA OTACÍLIO LOPES FILHO, 2013).
} 
Desintegrativos da Infância ${ }^{41}$ associados a Retardo Mental e comprometimento na acuidade visual. A casa da mãe é identificada como seu principal local de moradia e os tratamentos realizados até o momento foram: fisioterapia, equoterapia, fonoaudiologia, psicologia e psicopedagogia. Está estudando na classe especial de uma escola inclusiva.

$\mathrm{Na}$ medida em que consideramos essa breve caracterização das famílias adequada para o propósito de facilitar a compreensão das suas histórias e narrativas, partimos, nas seções subsequentes, para as descrições e análises desses elementos.

\section{3}

\section{Do Nascimento à Constatação da Deficiência do(a) Filho(a)}

Estudar os processos de (re)organização das famílias a partir da constatação da deficiência do(a) filho(a), no que se refere ao cuidado da prole, implica na necessidade de descrevermos ${ }^{42}$ as histórias de cada família, desde o nascimento da criança até o efetivo diagnóstico da sua deficiência.

\section{História da Família 1:}

A pessoa com deficiência da família 1 nasceu no tempo certo de gestação, mas precisou ficar na UTI após o parto, o que assustou a família, segundo narrativa da mãe:

\footnotetext{
${ }^{41}$ O Transtorno Desintegrativo da Infância é uma regressão pronunciada em múltiplas áreas do funcionamento. (...) Caracteriza-se por uma perda clinicamente significativa de habilidades já adquiridas e uma maior probabilidade de Retardo Mental (PSIQWEB, 2013).

${ }^{42}$ Esta seção trará o descritivo do período que vai do nascimento até a constatação da deficiência dos(as) filhos(as) das famílias sujeitos da nossa pesquisa. Não haverá preocupação com a análise, pois o intuito será aproximar-nos das histórias das famílias, a fim de que tenhamos elementos prévios para, nas seções seguintes, conhecermos e analisarmos como elas enfrentaram a comprovação da deficiência e se (re)organizaram em função dessa nova realidade.
} 
No dia que (a Filha 1) nasceu, na verdade eu fui por acaso fazer um exame, que era o exame do final da gestação; e a médica, na ultrassonografia, constatou que a (Filha 1) estava sem água, sem líquido. E a gente correu para a maternidade e ela nasceu na hora do almoço. (...) Então, ela nasceu com trinta e seis para trinta e sete semanas (...). Como ela tava sem água na bolsa, ela tava comprimindo o cordão umbilical, então os batimentos cardíacos dela tavam alterados. Ela nasceu com a glicemia limítrofe ali para dar uma hipoglicemia, e a gente... Ela ficou dois dias na UTI quando nasceu e a gente ficou bem assustado, sabe. (Mãe 1)

Ao ter alta da maternidade, a família enfrentou algumas dificuldades, como a de amamentação e a depressão pós-parto da mãe:

Mas ela saiu, (...) aí a depressão voltou; tive depressão pós-parto... Eu chorava pra caramba e ela mamava com dificuldade, dormia muito... (...) Teve dificuldade de mamar no peito. Ela não sugava, adormecia demais. (Mãe 1)

A constatação da deficiência da filha, na família 1, não ocorreu logo após o nascimento, mas aos poucos, a partir da observação dos pais e de outros familiares de que havia atraso no seu desenvolvimento. A esse respeito, a mãe 1 relata a inicial percepção dos pais sobre as diferenças da criança recém-nascida:

(A Filha1) parecia uma criança mais molinha e mais prostrada do que as outras. Era o tipo de coisa que é difícil de você ver numa criança dessa idade (...), mas a gente olhava e achava que ela se prostrava muito fácil. (...) É engraçado como a gente começou a perceber que tinha alguma coisa diferente com ela, né... (Mãe 1)

A entrevistada segue o relato em direção aos seis meses de vida da criança, dando continuidade à constatação gradativa da deficiência. Nesse período, não somente os pais, mas também pessoas próximas observaram diferenças em seu desenvolvimento, quando o compararam com de outras crianças da mesma idade cronológica:

Algumas pessoas falavam que ela era sossegadinha, que ela era muito preguiçosa e isso começou a dar na gente uma certa ansiedade, uma certa preocupação, né. Brincava muito com ela, estimulava, e ela começou a não corresponder como antes ela correspondia. Então, com seis meses de idade, ela continuou evoluindo, só que numa taxa menor do que você vê as outras crianças evoluindo. Era uma evolução mais lenta. Então a gente começou a ver atraso nos marcos de desenvolvimento. Rolar, ela chegou a começar a rolar e parou. [...] E dali pra frente, a gente viu que ela realmente ficou um pouco mais passiva. Ela não ia atrás dos brinquedos. A gente tinha que pedir muito, estimular muito, mostrar o 
brinquedo que ela gostasse muito para ela fazer alguma menção de ir pra cima daquele brinquedo. (Mãe 1)

A definitiva constatação dos comprometimentos da filha deu-se na faixa dos nove meses de idade da criança, quando o atraso no desenvolvimento tornou-se indiscutível. Foi nesse período que os pais buscaram ajuda profissional para investigação diagnóstica:

Lá pela faixa dos nove meses, ela ainda não engatinhava, não ficava na posição de quatro e ela só sentava com apoio. Então ela só sentava se você colocasse ela sentadinha; ela ficava sentada apoiada nas almofadas, mas ela não ficava sem apoio. E aí a gente via que o desenvolvimento motor dela tava BEM diferente das outras crianças. Aí que a gente começou efetivamente a investigar, [constataram]: 'não, realmente tem alguma coisa de errado'. (Mãe 1)

A narrativa da entrevistada, abaixo descrita, leva-nos a considerar que as pessoas de convívio mais próximo, tais como os familiares, embora possam servir como rede de suporte social (Bastos \& Deslandes, 2008), podem também, de maneira dual, funcionar como agentes estressores ${ }^{43}$, caso atribuam aos pais, a responsabilidade pelas limitações dos filhos. Essa constatação encontra fundamento no seguinte discurso:

Até chegar nessa investigação, a gente ouviu muita coisa [dos familiares]: 'ah, vocês são preguiçosos, ela é preguiçosa, vocês têm que estimular'; isso tudo vai, né... Você já ta vendo que a coisa ta esquisita, você já ta começando a ficar estressado com aquilo, e a família em volta, cobrando, estressando mais... (Mãe 1)

Nesse período, a filha 1 foi levada ao Neurologista, que confirmou o atraso no desenvolvimento. A partir de então, a criança iniciou uma série de terapias, a fim de estimular a evolução dos aspectos motores e cognitivos. Aos dois anos de idade, os pais levaram-na a um geneticista, que só então fechou o diagnóstico da Síndrome de Rett. Segue narrativa da mãe a respeito desse período:

Com a fisioterapia e terapia ocupacional ela melhorou; começou a evoluir e tudo mais, só que os comportamentos diferentes dela, é... continuaram. Aí, com uns dois anos a gente resolveu recorrer a um geneticista. (...) Eu me lembro bem dessa

43 Conceito apresentado por Minuchin (1982) para definir pessoas ou circunstâncias que representam maior estresse para o sistema familiar. 
consulta; ela [a geneticista] foi tão minuciosa! Ela olhava bem para (Filhal), olhava bem para a gente para ver os traços físicos e tudo. Ela falou: 'olha, não to vendo nela nenhum traço, é... nenhuma coisa física que me indique [uma síndrome]; mas o comportamental me chama muita atenção'. (...) E aí, juntando essas questões comportamentais [movimentos estereotipados, exploração pobre dos brinquedos, entre outras], ela pediu para a gente o exame do cariótipo e pediu exame para duas síndromes específicas: Síndrome de Rett e a Síndrome de Angelman (...). E aí a gente fez esses exames; levou aí quase sessenta dias para ficar pronto. (Mãe 1)

Embora a entrevistada tenha narrado que, desde cedo, ela e o marido perceberam algo diferente na filha, o casal negou ${ }^{44}$ a possibilidade da deficiência no período da investigação. Essa argumentação ancora-se no fato de que, enquanto eles não obtiveram exames e laudos comprobatórios, minimizaram os aspectos indicativos de uma síndrome ou transtorno. Tal minimização deu-se pela elaboração de explicações sobre os comportamentos diferentes da filha, que a distanciavam do diagnóstico de uma deficiência:

Até a gente conseguir ir no geneticista (...) começou a ficar mais evidente, é... o movimento estereotipado da mão. Que a gente achava que era uma ansiedade dela, ela levar a mão na boca. Então, quando a gente chegou no consultório da geneticista ela perguntou para mim: 'mãe, você sabe o que é estereotipia?' eu falei: 'não, nunca ouvi falar'. [Médica]: 'estereotipia é um movimento involuntário, repetitivo, sem funcionalidade alguma. Isso que sua filha ta fazendo com a mão é uma estereotipia'. (...) [pergunta da mãe 1]: 'Mas isso não é por que ela ta ansiosa? A tensão, né, por causa do dente...' aí a gente, né... [resposta da Médica]: 'não, isso é uma estereotipia'. (Mãe 1)

A negação dos pais também pode ser sinalizada quando a entrevistada relata a busca por características comportamentais e de evolução que afastavam a filha da possibilidade de ter Síndrome de Rett:

Eu saí do consultório completamente ignorante, né, porque eu nunca tinha lido nada sobre essas Síndromes. Meu marido, por alguns comportamentos dela, e pela hipotonia que ela tinha quando bebê, ele já tinha lido sobre Síndrome de Rett. Então ele já saiu mais... Só que a gente tinha na cabeça, né, que a Síndrome de Rett é muito característica pela regressão que as meninas têm nessa faixa etária. $\underline{E}$ embora ela tivesse algumas coisas pontuais, (...) ela tava evoluindo com terapia. Ela tava numa estimulação muito bacana. Na minha cabeça não era Rett, sabe.

44 A negação da deficiência, no momento inicial do diagnóstico, é abordada por autores como Silva \& Dessen (2001) e Góes (2004). 
[pensamento da mãe]: 'imagina, não é!' Aí a gente começa a ler sobre a síndrome e a gente começa a achar coisas que se assemelham e fica procurando outra coisa para contrapor a ideia. A gente fica meio que numa negação, tentando ignorar aquilo, né, [pensamento dos pais]: 'não, não é!' (Mãe 1)

O processo de negação dos aspectos indicativos da deficiência também foi sinalizado pela mãe 2 , conforme veremos na descrição da história da sua família.

\title{
História da Família 2:
}

Diferentemente da narrativa da mãe 1 e dos demais entrevistados, cujas histórias apresentaremos posteriormente, a pessoa com deficiência da família 2 teve sua Síndrome detectada precocemente ${ }^{45}$; logo após o parto. O que facilitou esse diagnóstico precoce foi a existência de uma característica física, que motivou a investigação e a confirmação da Síndrome de Freeman-Sheldon. Segue narrativa da mãe:

\begin{abstract}
Quando (a Filha 2) nasceu, a única indicação que a gente teve que ela teria alguma deficiência, teria algum problema, vamos dizer assim, foi que a Síndrome dela tinha uma das características (...) a mão é tortinha, porque o polegar é gerado em cima dos dedos. (...). Foi uma indicação que a gente teve de que tinha alguma coisa. E o pediatra que a atendeu falou o seguinte: 'eu sugiro que a gente chame um Ortopedista' - na época era uma pessoa muito reconhecida em nível de ortopedia, né - para fazer um diagnóstico. Então, ele [Ortopedista] foi, já no próprio hospital, acho que no segundo dia. Então ele fez alguns testes básicos que identificou que ela deveria ter uma Síndrome chamada Freeman-Sheldon, tá. (...) Ele falou assim: 'olha, ela vai ter que ser colocada num aparelho ortopédico. (Mãe 2)
\end{abstract}

O diagnóstico precoce da Síndrome não foi suficiente para impedir que a mãe 2 também ingressasse no processo de negação, por meio da minimização dos sintomas da deficiência. Essa consideração deve-se ao fato de que a entrevistada afirma ter tido dificuldade de perceber características da Síndrome na filha, tal como descrito no relato a seguir:

\footnotetext{
${ }^{45}$ Consideramos como 'detecção precoce da deficiência' os diagnósticos que ocorrem enquanto a criança é recém-nascida, preferencialmente ainda na maternidade (ANAUATE \& AMIRALIAN, 2007). Dessa forma, os casos em que as deficiências são descobertas pós-alta hospitalar, mediante observação da família e seguida de comprovação médica, estamos nomeando de 'constatação tardia da deficiência'.
} 
A mãe às vezes não quer ver os problemas, né? Aí mamãe [avó materna da filha 2] chamou a atenção da enfermeira do pediatra, que um dos lados da vulva dela era mais alto do que o outro. Ai ela falou: 'vou falar com o Dr. P L'. Ai ele viu e falou: 'ela tem um problema de hérnia inguinal'. Que é uma das caracteristicas também dessa Sindrome. (Mãe 2)

\title{
História da Família 3:
}

A constatação da deficiência do filho, na família 3, foi tardia; embora o recém-nascido já tenha apresentado complicações, conforme narrado pelo pai:

Então, é... essa questão da deficiência dele veio de uma forma tardia; (...) ele teve um problema de icterícia após o nascimento, esse negócio todo, e não havia assim um diagnóstico da, do... No caso dele da paralisia cerebral. Então o Médico dizia: 'ah, o fato dele tá molinho é por causa da hipotonia dele e todo aquele problema; e cada criança tinha um desenvolvimento diferenciado'. (Pai 3)

O filho 3 foi levado ao Médico especialista com um ano de idade, quando a família observou atraso no desenvolvimento. Só então foi confirmada a lesão cerebral, com comprometimentos motores e cognitivos. Segue a descrição do entrevistado:

\begin{abstract}
Quando fez a festa do primeiro ano dele [filho 3], que via que o desenvolvimento dele com o das outras crianças era... Não era ereto. Colocava ele sentado e sentia que a manifestação da hipotonia dele já tava avançada. E aí a (Mãe 3) foi falar com o médico: 'não, o desenvolvimento dele e das outras crianças tá muito diferenciado'. Ai ele foi fazer exames neurológicos, aquele fibro não sei das quantas, exame de partes musculares e essa coisa toda... Foi constatado que ele tinha uma deficiência de é... cognitiva, mas essa questão da hipotonia muscular; que foi a área que foi mais afetada desde pequeno. (Pai 3)
\end{abstract}

\section{História da Família 4:}

$\mathrm{Na}$ família 4, somente parte da deficiência, a cognitiva, foi constatada precocemente. $\mathrm{O}$ parto prematuro fez com que a criança precisasse ficar cinco meses na UTI, o que desorientou a família e gerou vicissitudes na sua organização. Segue relato a respeito desse período: 
[Com relação à prematuridade] você fica meio... Criança nasce antes do tempo, você fica meio assim... Ela tá indo para a UTI, você não leva ela pra casa, então você começa a ficar: 'epa, o que que tá acontecendo?' A ficha custa a cair, você demora um pouco a entender... Não é que você não entenda os acontecimentos, você não entende o porquê dos acontecimentos. Você não tem controle disso. (Pai 4)

Com relação às vicissitudes na dinâmica familiar, ocorridas ao longo da internação da criança na UTI neonatal, destacamos as três descritas abaixo, tomando como referência a narrativa do entrevistado.

1- Pais ficaram sem trabalhar, acompanhando o filho internado:

A (Mãe 4) ficou um certo tempo sem trabalhar; eu fiquei um tempo sem trabalhar também, depois eu voltei, mas ela ficou mais tempo ainda, ela ficou praticamente quase o tempo todo da UTI com ele. (Pai 4)

2- Adoecimento da mãe e enfrentamento de sentimentos de tristeza, culpa e preocupação, ao mesmo tempo em que tinham esperança na melhoria da saúde do filho:

Ela [a mãe] teve um quadro de depressão pós-parto; muito leve, mas teve. Ela ficou assim arrasada, você sentia que ela tava diferente... Mas ela passou muita coisa para ele. Talvez ela tenha sentido assim: 'por que eu não consegui ficar mais tempo com meu filho na barriga? Mas nunca falou isso também não. (Pai 4)

(Filho 4) morreu na UTI. (Filho 4) chegou a ter a parada, né, e foi ressuscitado. Ele voltou. Eu até brinco que eu virei Advogado especialista em UTI neonatal. (Pai 4)

Eu quando entrei a primeira vez [na UTI], já foi no final da tarde, para vê-lo, (...) eu olhava e falava: 'Oi, (Filho 4), que bom que você tá aqui, não sei o que...' e o olho dele brilhando. Ai eu lembro que eu falei assim, pensei, na verdade: 'oh, meu Deus, esse moleque vai vingar porque ele tem alguma coisa boa...' [choro] (...) E eu tenho certeza que passei muita força para ele. A (Mãe 4) também; apesar de a (Mãe 4) ter ficado um pouco mais fragilizada. (Pai 4)

3- Criação de rede de apoio com famílias que estavam vivenciando problemas semelhantes: 
Deus manda os anjos para a gente. E aí ele mandou dois anjinhos lá para mim [pai e mãe de um bebê que estava internado na UTI neonatal há cerca de dois meses]. (...) começamos a conversar, e eles ficaram até amigos nossos depois. Da gente frequentar a casa deles e eles frequentarem a nossa casa. E eu nunca esqueci uma frase que ele [pai do bebê] falou para mim: 'pai, fica tranquilo, esses nenezinhos são muito fortes.' (Pai 4)

O comprometimento neurológico do filho 4 foi constatado ainda na UTI neonatal, mas a comprovação da deficiência auditiva ocorreu tardiamente - após a alta hospitalar. Entretanto, antes de levá-lo a uma investigação, essa família também passou pelo processo de negação da possibilidade da deficiência. Essa afirmação está embasada no relato, que segue abaixo, de que os pais não achavam que a passividade da criança poderia significar uma deficiência auditiva, criando outra explicação para o fato:

\begin{abstract}
Quando a gente foi pra casa, a gente começou a perceber que o (Filho 4) era diferente em alguma situação. Num dado momento, a gente não via o (Filho 4) sobressaltado com nada. Via o (Filho 4) muito na dele, quietinho, mas achava que era a UTI, ter passado o que ele passou, ter sido muito manipulado... Não podia entrar ninguém de branco lá em casa, que ele ficava apavorado. (Pai 4)
\end{abstract}

A constatação da deficiência auditiva deu-se posteriormente, a partir da percepção da família 4 de que havia algo diferente com a criança, conforme narrativa abaixo:

Aí no Reivellon foi (...) aquele foguetol todo. Ele [o Filho 4] tava dormindo, mas eu peguei ele no colo. (...) Mas ele não acordou. Continuou dormindo no meu colo, passivo. Ele não mexeu uma pálpebra. Aí que a gente notou que havia alguma coisa diferente (...). E começamos a investigar. (Pai 4)

Após esse breve $\mathrm{e}^{46}$ conhecimento do processo de constatação da deficiência dos filhos das quatro famílias sujeitos da nossa investigação, seguimos para a

\footnotetext{
${ }^{46}$ As histórias das famílias 1 e 4 foram descritas de maneira mais extensa porque os entrevistados narraram por mais tempo e com mais detalhes esse período compreendido entre o nascimento e a constatação da deficiência do(a) filho(a). A mãe da família 2 possivelmente teve menos história para narrar a respeito desse período, porque a deficiência da sua filha foi constatada logo após o nascimento. Já o entrevistado da família 3, focou a narrativa na fase pós-constatação da deficiência, apresentando menor relato sobre o período prévio. Não julgamos necessário, entretanto, pedir, no fim da entrevista, para que ele retornasse à narrativa sobre o período anterior à constatação da deficiência, pois consideramos que seu breve relato foi suficiente para o que objetivávamos alcançar: uma primeira aproximação com a história de sua família.
} 
identificação dos significados da comprovação da deficiência para os pais e mães, a fim de que possamos conhecer as representações e sentimentos que influenciaram os comportamentos familiares nos momentos imediatamente posteriores ao diagnóstico.

\section{4 \\ Significados da Constatação da Deficiência do(a) Filho(a) para as Famílias Sujeitos da Pesquisa}

A comprovação da deficiência dos filhos fez com que os pais e mães da nossa pesquisa enfrentassem sentimentos como choque, angústia, tristeza e revolta. Trata-se dos sentimentos descritos na literatura corrente - apresentados em pesquisas que abordam sobre o impacto e as implicações da descoberta da deficiência de um filho para as famílias (Silva \& Dessen, 2001; Petean \& Neto, 1998; Góes, 2004). Tais sentimentos podem advir das representações negativas da deficiência que historicamente permeiam a nossa sociedade (Foucault, 2010a). Seguem as narrativas que versam acerca dos sentimentos gerados pelo diagnóstico:

Foi assim um choque para a gente. Primeiro porque a gente tentava negar o negócio: 'não, ela pode ter Rett? Não, ela não pode ter Rett!' Quando veio o diagnóstico, parecia que tinha caído uma bomba lá em casa. E aí, assim, tinha dias que eu chorava o dia inteiro, tinha dias que era meu marido que chorava o dia inteiro. (Mãe 1)

Eu fiquei meio perdido, eи fiquei meio assim... eи sou um cara que toquei bateria, eu gosto de música (...) Então é um impacto muito grande você ter uma questão que você gosta do som, ai você fala: 'caramba, ele não vai escutar, como é que vai ser a vida dele? Como é que vai ser a situação dele?' Você começa a ir para um lado negativo, depois você começa a pensar assim: 'não, não pode ser, não tem sentido.' (Pai 4)

A gente num primeiro momento começou a... eu não sei ... a (Mãe 4) se abateu muito. E eu comecei a brigar com Deus e com o mundo. (Pai 4)

E aí a neurologista lá que tratou dele, né, (...) falou para a (Mãe 3) logo assim: que ele JAMAIS andaria (...). Foi um impacto violento neste aspecto, né... Quer dizer, o Médico que recebe um diploma nunca deve usar esse tipo de coisa: jamais faz isso, jamais vai fazer aquilo outro. (Pai 3) 
A crítica, acima, do Pai 3 acerca da conduta do Médico enuncia o que foi revelado por Petean \& Neto (1998) a respeito do impacto da primeira notícia. Segundo os autores, a forma como a notícia da deficiência é dada pode influenciar as expectativas dos pais em relação ao desenvolvimento do filho; exacerbar ou minimizar os conflitos intrapsíquicos e interpessoais existentes entre o casal; dentre outros problemas.

As famílias também lidaram com o luto pela perda do(a) filho(a) esperado(a), o que pode ser explicado pela perda dos projetos de vida que eles tinham elaborado para aquele(a) filho(a) (Sprovieri \& Junior, 2001). Uma das narrativas aborda especificamente acerca desse sentimento de luto:

Aquela fase de luto, não sei te dizer quanto tempo que durou, mas assim, a gente ficou muito... muito arrasado, né, como se você tivesse... É um luto de um filho vivo. Então, na verdade, você ta enterrando as expectativas que você tinha em relação àquela criança. Então até passar aquele período de luto e a gente começar realmente a ver as coisas com mais clareza, não sei te dizer quanto tempo que durou isso. Durou alguns meses aí. (Mãe 1)

Todos os sentimentos já descritos nesta seção parecem-nos ser explicados pelo fato de que as famílias preparam-se para receber o que socialmente concebese como filho perfeito, ou para nos aproximarmos da definição de Szymansky (2012), o filho pensado: aquele que irá crescer sem limitações de ordens cognitivas, físicas ou comportamentais; que irá estudar, trabalhar e constituir sua própria família. Pais e mães não são ensinados a conviver com a possibilidade de conceber um filho que não terá as mesmas capacidades físicas e/ou intelectuais da maior parte das pessoas da mesma idade cronológica. E o fato de não se prepararem para essa possibilidade pode fazer com que haja um grande temor de cuidar de um filho que, inesperadamente, nasceu com deficiência. Ancoramos essas argumentações nos relatos de dois dos nossos entrevistados:

Você nunca espera que vai ter um filho com deficiência. Então, quando você recebe, você [pergunta]: 'ué, o que que aconteceu?' Então é realmente uma situação de muita confusão. Você não sabe realmente como você vai agir. Você espera uma criança saudável, sem nenhum problema e, na verdade, vem uma pessoinha totalmente diferente do que você imaginou. (Mãe 2)

O impacto foi um impacto assim: o cachorro caiu da mudança. Como é ter um filho especial? A gente não é ensinado a ter isso. (Pai 4) 
Percebemos que o filho 'perfeito' correlaciona-se com o que Szymansky (2012) define como família pensada. Esta prevê um modelo ideal de viver em família, por meio de uma estabilidade na relação pai, mãe e filhos. A chegada de um filho com deficiência modifica a ordem do pensado e as famílias têm de aprender a lidar com uma realidade que diverge das suas bases culturais. Essa família que diverge da pensada - a família vivida - terá de superar seus próprios preconceitos e o sentimento de inferioridade por não ter conseguido alcançar o modelo ideal.

Silva \& Dessen (2001), por meio de sua pesquisa, afirmam que o momento inicial é o mais difícil, mas que posteriormente as famílias buscam organização interna, a fim de construir um ambiente familiar mais preparado para incluir a criança. De fato, verificamos que as famílias da nossa investigação, cada uma no seu tempo, foram aceitando a realidade e criando mecanismos de adaptação; tal como exemplificado na narrativa abaixo:

\begin{abstract}
A gente teve que se adaptar, porque a gente não é criado pra isso (...). Aí um dia (...) Eu [pensei]: 'porque que eu to brigando? Por causa de uma audição? A gente vai dar um jeito nisso; a gente vai correr atrás disso'. Eu saí daquela coisa da reação ruim para a reação boa. Eu comecei a ver o que a gente podia fazer para tratar o (Filho 4). (Pai 4)
\end{abstract}

O desejo de reparação da deficiência, citado por Góes (2004), como afetos comuns, seria um exemplo de uma dinâmica familiar não contributiva para o desenvolvimento da pessoa com deficiência e para a saúde dos demais integrantes da família. A deficiência não vai deixar de existir; portanto, trabalhar na perspectiva de alcançar o impossível, pode causar ainda mais atraso no desenvolvimento do filho e frustração para todos os envolvidos. Como afirma Cavalcante (2007), é por meio da aceitação da condição da pessoa com deficiência que a família poderá descobrir forças para, de fato, ajudá-la.

Posturas familiares que caminham na direção da ajuda à pessoa com deficiência correlacionam-se com fatores como: superação da fantasia do filho idealizado; reconhecimento das suas limitações; busca de alternativas na sociedade para a estimulação de suas potencialidades; e percepção de cada aprendizagem do filho, como uma conquista importante, o que contrapõe a negação da deficiência e a expectativa de resultados para além de suas 
possibilidades (Cavalcante, 2007; Sprovieri \& Junior, 2001). A mãe da família 1 apresenta, em seu discurso, a dificuldade de aceitação das limitações progressivas da filha, logo após a constatação da deficiência; mas, em seguida, afirma terem, ela e o marido, conseguido modificar suas expectativas, adequando-as à realidade e às necessidades da criança:

É uma coisa que é difícil de você... até sua ficha cair e você realmente largar aquelas expectativas que você tinha em relação ao teu filho, ver as limitações dele e tomar isso como base, não para limitar o desenvolvimento dele, mas para se guiar para fazer o melhor para ele. (Mãe 1)

Então, você tem que ficar naquela batalha das terapias para manter uma qualidade de vida e... e se ficar naquele estágio, ta bom! Então, hoje a gente já fica feliz se ela se mantém do jeito que ela tá, o dia que ela come bem, o dia que ela dorme bem, o dia que ela não tem febre. Então, nossas expectativas hoje são totalmente diferentes das expectativas que a gente tinha. (Mãe 1)

É difícil a gente lidar com aquela questão do eu tenho um filho especial, mas eu queria que ele fosse normal. Não adianta! Tem um momento que você tem que, é... como é que eu vou te dizer, você tem que aceitar que aquela criança tem limitação e que você tem que se adaptar à vida daquela criança. Pode demorar um pouco, mas você vai ver os reflexos positivos da sua atitude. (Mãe 1)

Fica subentendido, na narrativa dos demais entrevistados, que também as famílias 2, 3 e 4 modificaram as expectativas e adequaram-se às necessidades dos filhos, na medida em que os inseriram em formas de ajuda na sociedade, visando atender às suas condições específicas, tais como terapias, atividades educativas especializadas e recursos sociais diversos. Trata-se de um dos principais processos de (re)organização familiar, ocorrido após a constatação da deficiência do filho; conforme abordaremos na seção 3.6.

\section{5}

\section{Processos de (Re)Organização das Famílias e o Cuidado do(a) Filho(a) com Deficiência}

Ter o cuidado como foco primordial de uma pesquisa que busca conhecer como as famílias (re)organizam-se a partir da constatação da deficiência dos filhos 
implica na necessidade de, inicialmente, situarmos os cuidadores desse segmento social no âmbito familiar. Verificaremos se entre os pais e mães sujeitos de nossa investigação - que são indivíduos de classes média e de elite, e com alto nível de escolaridade - há a manutenção de um padrão tradicional de divisão de tarefas no lar, conforme averiguado por Almeida (2011), em sua pesquisa com indivíduos de mesmo nível socioeconômico. Em seguida, partiremos para os demais aspectos relacionados à ação de cuidar, tais como as (re)organizações familiares, e os contextos que favorecem e dificultam o cuidado da prole.

Em conformidade com o que foi apresentado no capítulo 2, o conceito de cuidado será apropriado como compromissos contínuos de desvelo, bom trato e atenção aos aspectos social, físico, psíquico e emocional dos seres humanos (Boff, 201; Araujo \& Scalon, 2003; Tronto, 1997). Consideraremos a distinção entre os cuidados formal e informal (Carvalho, 2007), tomando o primeiro por atividade profissional e o segundo por atividade não remunerada; prestada, sobretudo, pela família.

\subsection{1 Identificação do Cuidador de Pessoas com Deficiência no Âmbito das Famílias Sujeitos da Pesquisa}

Nossa pesquisa corrobora a constatação de Sorj (2003), de que em famílias pertencentes a gerações juvenis, há maior flexibilidade das regras relacionadas à divisão de papéis de gênero. Essa afirmação justifica-se na medida em que, na família 1, que é formada pelo casal mais jovem dentre os participantes desta investigação, o pai e a mãe participam dos cuidados da filha com deficiência de maneira mais igualitária. Essa consideração foi feita pela própria entrevistada, mas também pôde ser extraída da forma como ela narra a história da sua família, situando a participação conjunta do casal nas tomadas de decisões relacionadas ao cuidado da filha, e a presença tanto da mãe quanto do pai nas ações de alimentar, brincar, estimular, oferecer carinho e dar atenção. 
Lá em casa sempre foi assim, bem... bem... nãa dá para dizer que um cuida mais, outro cuida menos. Hoje a gente já tem algumas tarefas mais divididas assim. Meu marido tem mais paciência para dar comida para ela. (...) A gente costuma brincar que a gente é uma equipe, né, que ele tem mais paciência para determinadas coisas e eu tenho a memória melhor para lembrar do remédio, da consulta, né, de fazer toda essa amarração, terapeuta, médico e tudo mais. Essa parte toda sou eu que faço. Então, de certa forma a gente se divide dentro do que cada um tem mais afinidade pra fazer. De maneira geral, a gente brinca muito com ela, faz muita bagunça, em termos assim de atenção e de carinho não existe diferenciação. (Mãe 1)

A Mãe 1, quando narra sobre as tarefas e decisões concernentes ao cuidado da filha, comumente utiliza a expressão 'a gente', referindo-se a ela e ao pai da criança; o que nos leva a supor a participação conjunta do casal. Segue, a fim de ilustrar essa nossa suposição, um trecho da narrativa sobre decisões compartilhadas a respeito do cuidado da filha: "A gente [o casal] sempre tá procurando conversar, né, sobre a manutenção da rotina da (Filha1), ou a necessidade da terapia e o risco da superestimulação" (Mãe 1).

Consideramos que o comportamento do pai da família 1 retrata a tendência contemporânea, registrada por autores como Araujo \& Scalon (2003), de um maior envolvimento masculino com os filhos. Orientando-nos pela divisão de papéis de gênero proposta por Tronto (1997), podemos considerar que ao realizar o trabalho direto de cuidar, homens, como o da família 1, ultrapassam o exclusivo papel de 'cuidado com' o dinheiro e a carreira, e inserem-se em atividades tradicionalmente consideradas femininas, que estão relacionadas ao 'cuidado de' pessoas.

Apenas quando a Mãe 1 fala sobre a organização das rotinas da filha, como ir às terapias e horários das refeições, ela deixa de mencionar a expressão 'a gente' e a substitui pela palavra 'eu'; o que nos permite constatar que essa responsabilidade é assumida exclusivamente por ela. Segue um dos relatos que exemplifica essa consideração: "Então hoje ela faz as terapias dela, também os horários de terapia, eu procuro negociar de acordo com os horários de refeição" (Mãe 1).

Esse gerenciamento do cuidado assumido pela mãe 1 conduz-nos a confirmar a consideração de Almeida (2011), de que, embora haja homens executando atividades de cuidado, a organização e administração dessas atividades permanecem sendo realizadas essencialmente pelas mulheres. 
Observamos semelhante movimento, de assunção das responsabilidades de administração e organização do cuidado pelas mães, nas demais famílias da nossa pesquisa. O que, de fato, diferencia essas famílias parece ser o grau de participação dos pais/homens nas demais atividades relacionadas ao cuidar do filho.

O pai 4, que é divorciado, relata ter a guarda compartilhada do filho com deficiência, o que confere a ele igualdade de direitos com a mãe na tomada de decisões relativas ao cuidado do rapaz. Entretanto, é a mãe quem organiza a rotina do filho; é na casa dela onde o rapaz identifica seu local de moradia; e é ela quem direciona os recursos que devem ser buscados para melhoria de suas condições físicas, psicológicas e sociais. Seguem os trechos da narrativa que ilustram essas afirmações:

Na separação, a gente tem a guarda compartilhada, mas pela própria legislação, ele tem que estar num lugar, numa referência dele. (...) Ele identifica as coisas dele na casa da mãe. (Pai 4)

Eu... por uma, não vou dizer comodidade minha, porque eu não uso o termo comodidade... Pode até ser! Mas eu confio muito no julgamento da (Mãe 4). Então quando ela chega pra mim e fala assim: '(Pai 4), o (filho 4) tem que fazer equoterapia, porque é uma coisa legal, não sei o que', aí eu vou pegar e vou ler, vou estudar. A iniciativa não parte de mim. (...) eu confio muito nela, na avaliação dela. (Pai 4)

Dessa forma, julgamos ser possível afirmar que o pai 4 pode estar incluído nas avaliações de Silva (2000) e Silva (2007), de que os pais/homens assumem um papel secundário no cuidado dos filhos.

Não se pode, entretanto, desconsiderar que certos comportamentos do Pai 4, caracterizados por expressões de afetividade - que estão culturalmente associadas a comportamentos femininos (Saraiva, 1998; Giffin \& Cavalcanti, 2012) reafirmam a tendência contemporânea de superação dos rígidos modelos de masculinidade e paternidade. Essa argumentação está respaldada na maneira emocionada e entusiástica com que ele descreve o amor e carinho que sente pelo filho. Segue uma das narrativas que demonstra a emoção desse pai ao referir-se ao filho com deficiência. "De vez em quando isso [o choro] vai acontecer, é normal; sou capricorniano, manteiga derretida (...)" (Pai 4). 
Seguem duas outras narrativas que ilustram nossa argumentação de que o pai 4 supera a rigidez dos modelos tradicionais de masculinidade e paternidade; a primeira por demonstrar vinculação afetiva com o filho e a segunda por valorizar o carinho como importante papel paterno.

[Leitura de mensagem de celular enviada para o filho]: 'Bom dia (Filho 4), papai muito feliz. (Filho 4) é o amor da vida de papai. Papai com muita saudade de (Filho 4). Muitos beijos, amor.' Sempre a gente termina assim: 'muitos beijos, amor'. (Pai 4)

Eu não deixei em momento nenhum faltar alguma coisa para ele, principalmente carinho. (Pai 4)

O carinho assumido e valorizado como papel paterno remete-nos ao conceito de paternagem (Lyra, 2010) ${ }^{47}$. De fato, o Pai 4, revelando a flexibilização das regras que separam o masculino do feminino, ultrapassa a função de provedor e envolve-se ativamente no cuidado do filho com deficiência; ainda que de forma secundária ao papel da mãe. Por esse motivo, ele é identificado pelos amigos como 'paizão', o que narra com orgulho e entusiasmo.

Quando eu tava com ele [na infância do filho 4], era muito engraçado, porque eu não parava na mesa, eu ficava atrás dele o tempo todo. Levava pro parquinho, ficava dentro da piscina, aquele negócio todo, e... era legal porque meus amigos, as meninas também, falavam assim: '(Pai 4), todo mundo aqui só chama você de paizão. Porque você com o (Filho 4) é uma coisa!' (Pai 4)

A participação do Pai 4 nos cuidados do filho nos dias atuais é exibida em relatos como os seguintes:

Eu pego ele todo final de semana. E não necessariamente ele dorme lá em casa. Às vezes ele sai comigo, eu chego sexta-feira e [falo]: 'vamo bora jantar'. Ai vamos pro shopping, não sei o quê (...). (Pai 4)

O cavalo [equoterapia], sou eu que levo ele. Levo no cavalo, depois levo pra almoçar (...). Aí se tiver de repente um almoço de algum amigo [pai pergunta]: 'vamo almoçar? É festa de um amigo de papai' (...). (Pai 4)

${ }^{47}$ Disponível na seção 1.1.3. (página 30). 
As duas narrativas transcritas confirmam a tendência contemporânea, sinalizada por Oliveira (2011), de que a participação dos pais/homens no cuidado dos filhos está ainda muito mais centrada nas atividades referentes ao mundo externo à casa, como passeios, ida à escola ou atividades recreativas.

Outra ressalva da literatura (Rizzini \& Menezes, 2010; Ridenti, 1998), que não pode ser desconsiderada ao analisarmos a participação paterna no cuidado dos filhos, é a de que a sociedade permite aos homens a assunção dos espaços tradicionalmente femininos, se eles mantiverem a provisão da família como seu papel principal. Talvez seja por essa capacidade de prover a contento e, em paralelo, cuidar do filho com deficiência, que o pai 4 seja admirado pelos amigos e apelidado de 'paizão'. O trecho de narrativa em que esse pai conclui ser o principal provedor, mas com funções que o distanciam do rígido modelo de papéis de gênero (Morgado, 2001; Bruschini, 1993), é o descrito a seguir: "Talvez eu seja mais assim, o financeiro, sem ser SÓ o financeiro". (Pai 4)

Importante observar, na narrativa acima, que o reconhecimento da função de provedor, vem aliado à defesa enfática de que seu papel não se resume a isso, o que demonstra que o pai 4 valoriza seu afastamento da rígida divisão que atribui ao homem o papel de provedor e à mulher o de cuidadora (Morgado, 2001; Bruschini, 1993). Essa valorização é reiterada quando ele demonstra certo desconforto ao concluir que é a mãe 4 quem assume a responsabilidade pelas decisões relativas aos tratamentos e recursos destinados à reabilitação do filho. A percepção de que esse papel também compete ao pai, parece fazer com que ele preocupe-se em justificar o motivo porque acredita estar a mãe do seu filho mais habilitada para essa tarefa. E essa justificativa não passa pela representação, advinda da ideologia patriarcal, de que ela, por ser mulher, tem o dom natural para a educação e o cuidado (Bruschini, 1993; Ridenti, 1998). Para o entrevistado, a Mãe 4, por ser profissional da área da saúde, tem mais acesso a informações a respeito da deficiência e suas formas de tratamento. Seguem trechos em que ele aborda esse assunto: 
Ela [mãe 4] é uma pessoa da área de saúde (...). Eu não. Sou da área jurídica, é um pouco mais complicado pra mim. (Pai 4)

Nesse ponto eu tenho uma vantagem, a (Mãe 4) é do MS [área da saúde] (...). Saca pra caramba, inteligentíssima, tem uma visão assim grande. (...) então, eu acho que ela entende as necessidades dele. (Pai 4)

A mesma justificativa para o maior envolvimento da mãe nas decisões concernentes à evolução do tratamento e educação do filho com deficiência está presente no discurso do Pai 3. "Como educadora que ela era, professora, ela [a mãe 3] tem mais sensibilidade do que eu nesse negócio de progresso"(Pai 3).

A família 3 aproxima-se mais do modelo tradicional de divisão de papéis de gênero no âmbito doméstico, uma vez que apresenta maior distanciamento dos pais/homens das atividades relacionadas ao cuidado dos filhos (Morgado, 2001; Bruschini, 1993). Semelhante processo ocorreu na família 2, no período da infância da filha com deficiência. Interessante observar que se trata de famílias, cujos filhos nasceram há mais de 30 anos, sinalizando-nos que, em gerações familiares mais antigas, pode haver menor flexibilidade na assunção masculina de tarefas concernentes à esfera privada (Sorj, 2003).

O contexto da família 3 segue o modelo clássico de família nuclear: pai atuante na esfera pública; mãe, sem atividade remunerada, administrando a esfera privada; e filhos residindo com eles (Morgado, 2001; Bruschini, 1993). O entrevistado dessa família, por vezes, quando relata alguma atuação conjunta do casal, em seguida corrige-se para afirmar que a atuação foi, na verdade, da esposa; permitindo-nos supor que o cuidado do filho com deficiência é assumido como responsabilidade exclusiva da mãe. Seguem algumas narrativas que elucidam essa observação:

Quando fechou essa escola, aí tivemos... a (Mãe 3) teve a indicação da tal da FM [outra escola]. (Pai 3)

Mas lá [em uma das instituições onde o filho 3 fez tratamento] também a gente viu... a (Mãe 3) viu que lá tem muita enganação. (Pai 3)

O nível de amizade que a gente tem com ela [com a responsável técnica da escola especial que o Filho 3 estuda], né, nos permite... a (Mãe 3) mesmo nessas reuniões [reuniões da escola com os pais], ela faz sugestões, coisas assim. (Pai 3) 
No que se refere à família 2, novos arranjos familiares foram formados desde a separação do casal. Atualmente, a mãe 2 vivencia outra união matrimonial, o pai está falecido e a filha 2 reside em uma moradia assistida; o que comprova o atual distanciamento do modelo clássico de família nuclear. Entretanto, na infância da filha 2, esse modelo predominava, tanto porque pai, mãe e filhos residiam na mesma casa, quanto porque o pai não assumia responsabilidades relacionadas ao cuidado da filha. Segue relato da mãe que explicita essa afirmação:

Olha, ele [o pai 2] nunca foi muito participativo. Sabe, nunca foi. (...) ele podendo deixar para uma terceira pessoa, que era minha mãe, ele deixava. E ele era canhoto, então ele sempre dizia o seguinte: 'ah, eu não sei botar fralda porque sou canhoto'. Eu [respondia para ele]: 'minha mãe é canhota, como é que faz?' Ele nunca foi muito participativo, na verdade. (Mãe 2)

Houve maior distanciamento paterno da filha 2 , que de seu irmão não deficiente. Refletimos se esse fato pode estar relacionado ao preconceito, oriundo de representações negativas da deficiência (Foucault, 2010a), ou aos sentimentos de inferioridade e vergonha do pai pelo não nascimento da filha idealizada (Góes, 2004). Esse distanciamento pode ser observado no discurso descrito a seguir:

[Distância paterna foi] Mais com ela! Porque me lembro com o (Irmão 2) a gente ainda saía... Mas com ela... Ela sempre ficava comigo, entendeu? A tendência era sempre deixar comigo. Ele [o pai 2] não participava muito não. (...) Quando era extremamente necessário ele fazia, mas podendo deixar para uma terceira pessoa, ou a mim, ou a minha mãe, ele deixava. (Mãe 2)

O relato acima também enuncia que a avó materna da filha 2 era participante ativa do seu processo de cuidado. $\mathrm{O}$ trecho de narrativa seguinte reitera essa afirmação:

Eram basicamente eu e minha mãe dentro dessa ideia de fazer o melhor pra ela. $O$ pai sempre é um pouco afastado, né? Acho que mãe e vó... mãe acho que é visceral $e$ vó é aquele carinho, minha mãe é muito carinhosa, sempre gostou muito de cuidar de criança. Então, me ajudou muito nessa fase. (Mãe 2) 
Para além do envolvimento da avó no cuidado, o relato acima desperta a atenção pela forma como a mãe 2 concebe o cuidado materno: visceral. Essa fala possibilita-nos observar uma naturalização do modelo mãe/cuidadora, estando em conformidade com o que a literatura aborda acerca da tendência ideológica de percepção do amor materno como natural, incondicional e abnegado (Saraiva, 1998; Bruschini, 1993; Almeida, 2011).

A autoavaliação heroica das mães, apresentada nos estudos de Bastos \& Deslandes (2008), também está retratado no discurso dessa entrevistada, quando enfatiza que nunca desistirá de buscar o melhor para a filha:

Desistir da casa [moradia assistida onde a filha reside] é desistir da minha filha. E da minha filha, eu não vou desistir NUNCA! (...) É minha filha, então não vou desistir. (Mãe 2)

A justificativa apresentada para o esforço desmedido em prol da filha 2 é o simples fato de ela ser sua filha, o que nos permite confirmar a constatação de Saraiva (1998), de que a condição biológica de gerar um filho no ventre faz com que as mulheres sejam percebidas, inclusive por elas próprias, como seres com capacidade natural e ilimitada para amar e cuidar da sua prole.

Além da família 2, que contou com o apoio da avó materna para o cuidado da filha com deficiência, todas as demais famílias sujeitos da nossa investigação contaram, ou ainda contam, com significativo apoio de alguma mulher - para além das mães - na assunção da tarefa de cuidar do(a) filho(a) com deficiência. $O$ que diferencia as referidas famílias nesse aspecto é o tipo de cuidado exercido por essas mulheres: formal ou informal (Carvalho, 2007).

A família 1 conta com o apoio do trabalho remunerado de uma cuidadora profissional, que exerce, portanto, o cuidado formal. A família 2 recebeu o apoio de uma cuidadora informal, a avó materna, ao longo da infância da filha com deficiência; atualmente, a filha 2 é assistida por cuidadoras formais em seu local de moradia. A família 3 contou com o cuidado informal exercido pela avó materna, enquanto ela era viva. Já a família 4, contratou uma empregada doméstica que a auxilia no cuidado do filho e está recebendo aulas de língua brasileira de sinais, para que a atividade de cuidar seja exercida a contento. Tais afirmativas podem ser observadas nos seguintes relatos: 
Ela [a cuidadora] participa bastante também dessas decisões que envolvem o cuidado. É ela quem está no dia de semana, quem toca aqui a questão dos horários, das terapias e tal. (Mãe 1)

Agora nós tamos com dois grupos de cuidadores [na moradia assistida, onde reside a Filha 2], um fica segunda, quarta e sexta e o outro terças, quintas e sábados. (Mãe 2)

A minha sogra dava muito apoio, né. Mas depois que minha sogra faleceu a (Mãe 3) teve que acumular essa parte. (Pai 3)

Uma empregada dela [da mãe 4], que ajuda, que aprende libras também com a (T) [Psicopedagoga]. (Pai 4)

A presença dessas pessoas do sexo feminino - para além das mães - no exercício do cuidado formal ou informal dos filhos com deficiência pode ser um indício da permanente concepção, socialmente arraigada, de que as mulheres possuem habilidades para o cuidado, por estarem associadas a qualidades altruístas como sensibilidade, afetividade, delicadeza e devoção ao próximo (Quintaneiro, 1995).

O papel dessas mulheres foi valorizado, sobretudo, nas entrevistas das famílias 1 e 2, pois o apoio no cuidado dos filhos com deficiência tem possibilitado que as mães permaneçam no mercado de trabalho; conforme relatos abaixo:

Eu participei muito da questão da terapia dela [da filha 1] no começo. $\underline{\text { Hoje, com }}$ a cuidadora, eu já vou mais esporadicamente, porque eu tenho que tá no trabalho. (Mãe 1)

Minha mãe me ajudou muito! Minha mãe foi uma pessoa assim fundamental para minha vida profissional. Porque eu poderia deixar de trabalhar por causa dela [da filha 2], e minha mãe sempre me ajudou (...) Eu tinha toda liberdade de trabalhar. Não precisei deixar de trabalhar porque minha mãe tava sempre presente. Isso foi muito importante. (Mãe 2)

Não se cogitou, em nenhuma das narrativas, que os homens tivessem de deixar o mercado de trabalho para cuidar do(a) filho(a), mas essa possibilidade é cogitada para as mães, possivelmente por elas serem consideradas as principais cuidadoras da esfera privada, associado ao fato de que a condição da deficiência dos seus filhos demanda necessidades específicas e prolongadas de cuidado. Avaliamos que essa possibilidade de abandonar a atividade remunerada, que se 
apresenta como um risco para as mães 1 e 2 e que foi uma realidade para a mãe 3 , seja um indicativo do que afirma Ridenti (1998): as mulheres possuem legitimidade social para atuar na esfera pública, se forem capazes de articular o trabalho remunerado com as tarefas domésticas e familiares. Caso essa dupla jornada esteja prejudicando o âmbito privado do lar, fundamentalmente o cuidado dos filhos, essas mulheres poderão ser socialmente criticadas e desvalorizadas, ainda que estejam atuando com sucesso na esfera pública (Ridenti, 1998). Dessa forma, contar com o apoio de outras pessoas para o exercício do cuidado dos filhos, sobretudo se essas pessoas forem mulheres - devido às representações sociais da condição feminina - possibilita às mães trabalharem no espaço extralar, sem maiores pressões sociais contrárias; porém, desde que elas sejam capazes de administrar a rotina doméstica (Ridenti, 1998).

A busca pela identificação dos cuidadores dos filhos com deficiência, empreendida nesta seção, permitiu-nos, também, um prévio conhecimento de elementos que caracterizam os processos de (re)organização familiares em relação ao cuidado da prole; tais como: divisão de tarefas entre os pais e mães das pessoas com deficiência, sendo essa mais igualitária na família pertencente à geração mais jovem; administração feminina das rotinas relacionadas ao cuidado dos filhos; contratação de profissionais cuidadores, o que possibilitou às mães das famílias 1 , 2 e 4 manterem-se no mercado de trabalho; e o cuidado do filho 3, assumido exclusivamente por sua mãe, o que a impossibilitou de continuar exercendo atividades remuneradas extralar. Buscaremos, na seção seguinte, ampliar o conhecimento sobre como (re)organizaram-se as famílias sujeitos da nossa investigação, a partir da constatação da deficiência de seus filhos, em particular no que se refere ao cuidado da prole.

\subsection{2 \\ Processos de (Re)Organização das Famílias Sujeitos da Pesquisa, a Partir da Constatação da Deficiência do(a) Filho(a)}

Nossa análise parte do entendimento de que a constatação da deficiência do(a) filho(a) não se configura, necessariamente, no primeiro acontecimento que 
incita organização familiar (Minuchin,1982). Pensamos, entretanto, que a deficiência não tende a ser percebida pelas famílias como um acontecimento impulsionador de adaptações do mesmo grau de importância dos que o antecederam, já que os anteriores, em geral, configuram-se como crises previstas - as quais demandam reordenamentos das ações familiares, porém são superadas com maior facilidade (Minuchin, 1982). A deficiência é enfrentada pelas famílias como algo significativo (Petean \& Murata, 2000), uma crise imprevisível (Minuchin, 1982), que implica em mudanças consideráveis nas dinâmicas familiares (Sprovieri \& Junior, 2001; Petean \& Murata, 2000) e deflagra a necessidade de mobilizar recursos externos para seu enfrentamento (Minuchin, 1982).

No que se refere às famílias, sujeitos da nossa pesquisa, as mudanças e ajustes nas rotinas tiveram pontos convergentes e outros que se diferenciaram; o que já era esperado, considerando as especificidades educativas e terapêuticas de cada pessoa com deficiência (Honora \& Frizanco, 2008), e os fatos de que cada família possui sua própria dinâmica e o cuidado familiar ocorre a partir do mundo de significados de cada uma delas (Stamm \& Mioto, 2003). A ocorrência de adaptações nas organizações familiares causadas pela constatação da deficiência do(a) filho(a) está coerente com o que descreve Minuchin (1982) sobre a capacidade que os indivíduos integrantes do sistema social família têm de influenciá-lo, provocando mudanças nas ações e pensamentos dos demais integrantes desse sistema.

Os processos de (re)organização ocorridos, a partir da constatação da deficiência do(a) filho(a), deram-se por meio de: mudanças e ajustes contínuos nas rotinas familiares para adaptação à nova realidade; inserção dos filhos com deficiência em apoios continuados de profissionais e instituições especializadas; busca cotidiana de pais e mães, pelo que entendiam como melhor atendimento às necessidades do(a) filho(a); e procura por ajuda profissional que auxiliasse os integrantes da família a lidar com a pessoa com deficiência, o que foi relatado exclusivamente pela mãe 2 .

Dentre os sujeitos da nossa pesquisa, a mãe 1 foi a que destacou, em seu relato, sofrimento familiar com as mudanças de rotinas, o que pode ser justificado pelo fato da família precisar adaptar-se às perdas de capacidades antes adquiridas pela criança, em função de sua deficiência progressiva. Algumas necessidades de 
(re)organização foram consideradas como um segundo luto para os pais, o que nos permite a compreensão de que houve um retorno ao sentimento de morte do filho idealizado (Petean \& Neto, 1998; Góes, 2004). Seguem trechos de narrativa acerca do enlutamento provocado pela retirada da filha da escola e sobre a consequente adaptação das rotinas da família a esta nova condição, visando prestar o que os pais entendiam como a melhor forma de cuidado da criança:

Vou te dizer aí, da época do diagnóstico dela, que foi com dois anos e quatro meses, até agora, que ela tá com cinco anos, a gente teve algumas mudanças bem significativas, né... Em casa, e na maneira como a gente trata ela. Enquanto ela tinha ainda, é... Enquanto a Síndrome não havia se instalado nela de uma forma mais severa, né, ainda tava bem na escolinha e a gente foi deixando ela lá. Quando chegou com uns três anos de idade, que ela começou a ter refluxo e convulsão foi uma época assim... Foi como se fosse um segundo luto para a gente. Foi a época de a gente parar e pensar: 'será que vamos manter na escola? A escola para ela, do jeito que ela tá hoje, é segura?’ (Mãe 1)

Então, assim, foi realmente um segundo luto ter que tirar ela da escola. O primeiro foi o diagnóstico, o segundo foi a tirada da escola. E aí acho que a tirada da escola foi o ponto de virada de que a gente realmente precisava ajustar nossa vida para ela ter mais qualidade de vida e também isso ia acabar impactando em toda a família; em nós três. Então, ela começou a fazer só as terapias dela, a gente teve que correr atrás de uma pessoa para ficar com ela em casa, uma cuidadora e também uma empregada. (Mãe 1)

Os relatos sobre o luto vivenciado pela família 1, em decorrência do acirramento da Síndrome da filha, vai ao encontro do que Minuchin (1982) denomina de estresses em torno de problemas idiossincrásicos: o sistema familiar teve a crise ampliada na medida em que a criança cresceu e a disparidade do desenvolvimento entre ela e outras crianças da mesma idade cronológica tornouse ainda mais evidente.

Para reduzir as desvantagens ou retardar a progressão da deficiência, a família 1 inseriu-a em serviços de habilitação e reabilitação prestados por profissionais e instituições especializadas, o que demarca um ponto em comum nos processos de (re)organização de todas as famílias sujeitos da nossa pesquisa.

Então ela [filha 1] teve fases; teve fase que teve que investir muito na questão motora. Teve uma fase que a gente pôde aliviar um pouco a questão motora e tratar dessa questão mais cognitiva, e agora ela deu uma piora motora, então a gente vai ter que equilibrar de novo o cognitivo com o motor. Então, na verdade quem vai guiando todo esse processo é ela, e a gente tem que tá atento aos sinais que ela dá, né: ansiedade, uma inquietação, a questão da saúde dela de uma 
maneira geral. A gente vai tateando por isso, para ver se ela tá indo bem ou não. (Mãe 1)

No que se refere aos dias atuais, a mãe 1 narra que a organização familiar está ajustada conforme necessidades da filha com deficiência, o que corrobora a conclusão de Petean \& Murata (2000), de que a presença da criança com deficiência altera a dinâmica familiar, provocando reestruturação nas vidas dos seus membros. Seguem relatos da entrevistada que ilustram essa afirmação:

Então, como que a gente se ajustou de lá para cá: (...) Tudo é voltado para a rotina dela [da filha 1]. Tem os horários dela de remédio preestabelecidos, principalmente os remédios de convulsão. Então tudo tem que ser encaixado, né. Dependendo do remédio, você tem que conciliar com alimentação para ela conseguir engolir a medicação. Então tudo é ajustado (...) Então a rotina funciona com base nela. (Mãe 1)

Então, na verdade, ela não fala, mas ela manda em todo mundo [risos]. E a gente foi se adaptando dessa forma. E a resposta dela mostrou pra gente que a gente tá indo no caminho certo, que realmente é isso aí. (Mãe 1)

Quanto à (re)organização das rotinas da família 3, um ajuste marcante foi a mudança definitiva da mãe e do filho com deficiência da cidade de São Paulo para o Rio de Janeiro; onde o Pai já estava residindo, por motivos de trabalho. "A (Mãe 3) tava trabalhando como professora lá em São Paulo, então a maior parte do tempo ela tava lá. E fim de semana ela vinha ou eu ia pra lá (...)” (Pai 3).

A saída de São Paulo significou o retorno dos integrantes da família ao mesmo domicílio e o abandono do emprego da mãe 3. No Rio de Janeiro, ela passou a assumir o exclusivo papel de cuidadora. $\mathrm{O}$ marido permaneceu em sua atividade remunerada e assumiu a exclusividade pelo provento do lar. Podemos constatar, portanto, que o processo de (re)organização da família 3, a partir da comprovação da deficiência do filho, contribuiu para reforçar o modelo clássico de família nuclear burguesa (Morgado, 2001; Bruschini, 1993). 
Aí a (Mãe 3) veio morar aqui no Rio com o (Filho 3), né, aí começamos a parte de fono [fonoaudiologia], de fisio [fisioterapia] (...). (Pai 3)

Ela [mãe 3] ficou por conta do (Filho 3), né. Eu poderia até botar uma pessoa para cuidar dele, mas ela não... A gente não confia muito. Porque a gente vê tanta coisa que acontece por aí, né?

Esse retorno da família 3 ao mesmo local de moradia, reajustando-se a fim de melhor atender às necessidades de cuidado e tratamento da criança, permitenos considerar, também, que a constatação da deficiência do filho resultou no fortalecimento dos limites em torno da família nuclear, o que é uma possibilidade prevista por Minuchin (1982), em situações de crises previstas ou imprevisíveis. Esse fortalecimento não significa, entretanto, que a família 3 fechou-se para o contexto exterior. Ao contrário, ela recorreu a apoios continuados da sociedade, ao longo de toda a história de vida do filho com deficiência, inserindo-o em serviços terapêuticos e educacionais especializados. Seguem partes do relato sobre as instituições de ensino especial, escolas inclusivas e unidades de tratamento pelas quais o filho 3 passou:

Aí nós ficamos conhecendo aqui no Rio, é... Aquela clínica que fica ali no Humaitá (...) Aí depois apareceu uma outra escola que era lá no Jardim Botânico, que era... Era até de um casal de Italianos e era inclusiva. E o (Filho 3) começou a frequentar essa escola (...) Para criar o vínculo, né, por ele ter esse retardo motor e tudo mais (...). Ah, tem um detalhe interessante: ele foi alfabetizado na escola que fica lá no Méier. (...) Para mim essa escola era espetacular. A casa, embora não oferecesse muitas condições, mas a equipe que trabalhava lá era espetacular. $O$ (Filho 3) saiu alfabetizado de lá e tinha a letra cursiva, perfeita. (...) Quando fechou essa escola, aí tivemos, a (Mãe 3) teve a indicação da tal da F M [escola especial] (...). Bem, essa $F M$, era um espetáculo essa escola, todos [os profissionais] tinham pós- graduação, tinham doutorado, mestrado (...). Mas na realidade, ele [filho 3] regrediu uns quatro, cinco anos. Lá ensinavam uma coisa, não tinha tratamento diferenciado, jogaram ele lá e a gente via que ele não tava progredindo. (...) Ele perdeu a escrita dele cursiva, não perdeu a alfabetização, não, mas a agilidade (...). Então eu sei que tiramos ele de lá. (Pai 3)

Como é lá o nome do negócio lá no Morro dos Macacos? [instituição especializada em habilitação e reabilitação de pessoas com deficiência] Eu até era contra o (Filho 3) frequentar lá, mas ele gostava. (...) Lá tem oficina de padaria, de marcenaria... (Pai 3)

$\mathrm{Na}$ narrativa sobre a história da família 3, deu-se grande enfoque aos serviços terapêuticos e educacionais prestados à pessoa com deficiência, incluindo 
elogios e críticas aos diversos trabalhos desenvolvidos; como apresentado nos dois relatos acima. Esse foco nos serviços possibilita-nos supor que a referida família confere grande importância ao cuidado formal - exercido por profissionais (Carvalho, 2007) -, percebendo-o como trampolim para o desenvolvimento motor, social e intelectual do filho com deficiência. Cavalcante (2007) demonstrase entusiasta desse processo, por considerar que se a família isolar-se e não inserir o(a) filho(a) em apoios continuados de diversos tipos, a deficiência será um fardo para todos, e o desenvolvimento psíquico e social do filho ficará prejudicado. A autora alerta, entretanto, para o risco da sobrecarga de tratamentos, já que esse movimento pode ser responsável por 'traumatizar' a pessoa com deficiência, principalmente por causa do modo fragmentado com que os profissionais costumam tratá-las (Cavalcante, 2003). O Pai 3 relata que essa sobrecarga ocorreu em uma das primeiras unidades terapêuticas frequentada pelo filho:

Eu particularmente achava o negócio [método utilizado pela unidade terapêutica] massacrante; seja pelo seguinte (...) botava a criança lá para fazer o negócio, ficar dando volta; tinha pessoas de diversos tipos. $O$ (Filho3) infelizmente ele sente dor. Aí ficava no engatinhamento até o joelho ficar em carne viva... Chegou a um ponto lá que o (Filho 3) criou trauma lá com essa tal NS G [unidade terapêutica]. E hoje em dia até quando a gente quer ameaçar o (Filho 3), a gente fala: 'oh, você vai voltar para a N $S G^{\prime}$ [risos]. Ele faz qualquer coisa para não voltar para lá [risos]. (Pai 3)

A situação descrita acima, a superestimulação que gerou 'trauma', não nos parece ter ocorrido porque a família considera-se incapaz de cuidar do filho com deficiência, deixando essa tarefa a cargo da instituição. Fundamentamos essa conclusão no fato de que, ao longo de toda a narrativa do entrevistado, ele cita a participação, o questionamento e a intervenção constante da família principalmente da mãe 3 - no processo terapêutico e educacional do filho com deficiência. Nos dias atuais, o rapaz está estudando e realizando tratamentos e atividades indicadas para sua atual condição de saúde; o que demonstra o investimento da família no seu desenvolvimento e bem-estar. 
Agora ele [filho 3] tá na escola da (E) [nome da Responsável Técnica da escola]. (...) A (E), por exemplo, não pretende ganhar em cima da escola. Ela diz que muitos dias lá ela tem que botar o dinheiro. (...) Porque a gente tem muito medo dessa tal de escola que na verdade é um depósito. Então a gente tá tentando! (...) Ele precisa fazer fisio [fisioterapia], fazer fono [fonoaudiologia], fazer pilates, né, porque agora ele teve até problema de osteoporose. Ele tá fazendo academia, tem que dar uma alimentação especial... (Pai 3)

Essa busca pela reabilitação e pelo desenvolvimento das potencialidades do(a) filho(a) foi apresentada no discurso de todas as demais famílias sujeitos da nossa pesquisa; apresentando-se, entretanto, como um difícil processo de tentativa e com foco no bem-estar da pessoa com deficiência. Essas considerações podem ser elucidadas em relatos como os descritos a seguir:

\begin{abstract}
Mas eu acho, na verdade, que a (Filha 2) teve a sorte de nascer numa família muito amorosa, muito afetuosa, que, apesar de ter sido muito difícil, a gente conseguiu superar uma série de coisas. Dificuldades mesmo. Nada foi rapidinho e nada foi simples, foi sempre com muita... preocupação. Mas o desejo maior nosso é que ela tivesse bem. Por isso a gente sempre teve a preocupação em tentar descobrir as coisas, encontrar as coisas para fazê-la sentir bem, sentir uma pessoa feliz. (Mãe 2)
\end{abstract}

[Busca pelo desenvolvimento do filho é] como se fosse assim... você tira uma peça, coloca num lugar, pega outra, coloca aqui, e vai arrumando até a coisa ficar bem arrumadinha. É como se fosse tentativa e erro; deu errado, faz de novo, faz de outro jeito. (Pai 4)

E felizmente na nossa família (...) todos [pais e irmãos] procuram ajudar, né, nesse negócio do desenvolvimento do (Filho 3). Então, quer dizer, a gente viu que a gente tinha que cuidar dele com todo carinho. (Pai 3)

Você [precisa] compreender que o teu filho é diferente. Não significa que ele vai ser mais ou menos feliz. Você tem que realmente batalhar, dentro da limitação dele, para que ele tenha uma qualidade de vida (...). Porque não é uma coisa, assim, simples e imediata. (Mãe 1)

A participação ativa das famílias no processo terapêutico do(a) filho(a) com deficiência vai ao encontro das tendências contemporâneas de valorização do papel familiar no cuidado em saúde (Wetzel et a., 2009; Ortiz et al., 2011).

No que se refere à presença da família 4 no cuidado da saúde do filho com deficiência, foram relatadas a busca por serviços médicos e terapêuticos que melhor atendessem às necessidades específicas do rapaz e à adaptação nas rotinas 
do pai e da mãe, mesmo após o divórcio do casal, para levá-lo aos tratamentos; o que demarca os principais processos de (re)organização vivenciados por essa família.

E aí começamos a fazer todos os procedimentos de acompanhamento e tal (...) (Pai 4)

Fomos para Bauru fazer o implante coclear ${ }^{48}$, porque a gente já tinha indicação. Lá (...) é Centro de Referência. E... Continuamos no (C) [hospital de referência na área crânio-facial], aí ele entrou na lista do implante, mas passado um bom tempo que ele vai lá (...). Tiraram ele da lista de implante, pois ele tem ganho auditivo, ele se comunica por libras, ele entende labial, aquele negócio todo... (Pai 4)

A (T), Psicopedagoga, tá em casa [atende na residência do Filho 4]. A (M), que é Psicóloga, é uma casa [atende em uma casa]; lá é muito legal por sinal. Ela [a mãe 4] leva [para a Psicóloga] ou a (M) [empregada doméstica] leva, porque ela [a mãe 4] tá trabalhando; e eu vou lá e pego. O cavalo [equoterapia], sou eu que levo ele (...) (Pai 4)

A história da família 4, como as das demais famílias da pesquisa, elucida a afirmação de Petean \& Murata (2000), de que a deficiência do(a) filho(a) altera a organização familiar e reestrutura a vida dos seus membros. Para atendimento às necessidades provenientes da deficiência auditiva do filho 4, os pais fizeram adaptações na casa e aprenderam a interpretar a língua brasileira de sinais.

Aprendemos libras, aprendemos a nos comunicar com ele. (Pai 4)

Então eu montei a casa pro (Filho 4). (...) A casa tem campainha que a pessoa aperta, além do barulho tem a luzinha piscando lá. Tem rede, tem grade, tem que ter essas coisas (...). (Pai 4)

Também na narrativa sobre a (re)organização da família 2 foi dado destaque para o cuidado em saúde, por meio da busca de atendimentos terapêuticos especializados.

Ela [Filha 2] teve que fazer fonoaudiologia (...). Ela fez mais ou menos uns oito anos de fonoaudiologia, que não ajudaram praticamente em nada. Depois a fono

\footnotetext{
${ }^{48}$ Implante coclear é uma cirurgia que consiste na "implantação de um equipamento eletrônico computadorizado que substitui totalmente o ouvido de pessoas que têm surdez profunda". (HONORA \& FRIZANCO, 2008, p.66)
} 
pediu uma Psicóloga. Eu acho que aí na parte da Psicóloga ajudou um pouco mais, porque... não sei o quanto ela sentia um pouco angustiada por não falar. (...) ela não gostava muito de contato, de toque, entendeu? Hoje é uma beijoqueira... Beija, abraça... [risos] Então, eu acho que a Psicóloga foi importante. Ela ficou mais ou menos uns oito anos na Psicoterapeuta e acho que isso ajudou muito, essa parte afetiva dela. (Mãe 2)

O diferencial relatado pela mãe 2, quando comparado às demais famílias pesquisadas, foi o fato de o cuidado em saúde ter sido buscado não apenas para a filha com deficiência, mas também para os demais integrantes da família 2; a fim de que pudessem obter auxílio profissional para lidar com a criança.

Foi tudo um aprendizado, né, foi muito interessante... E depois que ela [a filha 2] fez terapia, eu e (Pai 2) tivemos também que ir para a terapia. Também ajudou muito. De uma certa forma, o que acontece... a mãe que tem uma filha deficiente, ela faz TUDO para atender a criança, a pessoa deficiente. E não é assim! Você tem também que dar disciplina, você tem que dar limites como qualquer pessoa. (Mãe 2)

Eu ficava muito preocupada com negócio de limpeza e quando ela [a filha 2] comia, eu fazia questão de dar na boca dela para ela não sujar. Mas a terapeuta falou assim: '(...) Deixa ela comer, deixa ela experimentar'. E realmente, é muito melhor você comer com sua mão do que com a mão dos outros. (Mãe 2)

Stamm \& Mioto (2003) são entusiastas desse apoio profissional às famílias para que possam exercer o melhor cuidado em saúde; cabendo a esses profissionais fortalecer, apoiar e orientar as famílias quando as encontrarem fragilizadas. O apoio dos terapeutas auxiliou a família 2 a reduzir a proteção excessiva, o que Boff (2011) nomeia de patologia do cuidado, já que essa ação pode paralisar e prejudicar a espontaneidade de quem o recebe.

Nos dias atuais, o pai 2 está falecido e a filha reside em uma moradia assistida com outras pessoas com deficiência; estando sob cuidados de profissionais cuidadores. A mãe organiza sua rotina, em relação ao cuidado da filha, indo semanalmente à sua moradia para visitá-la, para acompanhar o trabalho desenvolvido pelos cuidadores e para verificar as condições do ambiente. Uma vez por semana, a mãe 2 leva a filha para sua casa para prestar os cuidados de higiene que os profissionais tiveram maior dificuldade de realizar. 
E a partir de 2004... ou 2005... apareceu esse projeto da moradia assistida. Então ela [filha2] está morando lá há cinco anos e tá super bem, super entrosada. É... Eu vejo que... Toda terça-feira eu levo ela para casa; eu sempre digo que não sei se ela precisa, mas EU preciso que ela vá lá pra casa [risos]. Preciso fazer um check up de unha, ouvido... Eu sei que ela é bem cuidada, mas alguns cuidados do tipo... Por exemplo, cortar unha, escovar os dentes, elas [as cuidadoras] não conseguem. (Mãe 2)

Eu vou todo domingo na casa e toda terça-feira eu tenho que pegar para fazer esse check up geral. (Mãe 2)

O fato de a mãe 2 ter optado por inserir a filha com deficiência no projeto de moradia assistida não nos parece ser justificado pelo seu sentimento de incapacidade de prover o cuidado; o que é uma realidade para algumas famílias, segundo Macedo \& Rosa $(2010)^{49}$. Essa consideração ancora-se nos relatos abaixo, que abordam sobre a presença permanente da mãe na casa, questionando os cuidadores e intervindo no cuidado da filha. Também não podemos afirmar que a filha 2 está sendo desrespeitada no seu desejo de estar com a família, uma vez que a mãe é bastante presente, e afirma que a filha gosta da moradia e está muito bem entrosada.

\begin{abstract}
Então eu tô sempre muito presente, sempre pontuando muita coisa [em relação à moradia assistida]. (...) Eu acho que a gente não pode ser permissiva em nenhum momento. Eu digo sempre o seguinte (...) não considerar a casa [moradia assistida], não ligar para a casa, é não ligar para minha filha. E eu não desisto. Já passamos por crises MUITO sérias na casa, muito sérias, mas até uma mãe falou (...): 'ah (Mãe 2), eu te admiro que você não desiste.' Eu falei: 'desistir da casa é desistir da minha filha. E a minha filha eu não vou desistir NUNCA!' (...) O que eu posso fazer, se a casa tiver horrivel, é tirar minha filha de lá; o que eu não gostaria porque ela gosta da casa. (...) Então tô sempre em cima, tô sempre cobrando, tô sempre fiscalizando (...). (Mãe 2)
\end{abstract}

Eu já falei com as meninas [cuidadoras]: 'deixa ela [filha 3] comer sozinha. Vocês só arrumem a comida, deixa ela comer sozinha. '(Mãe 2)

O respeito aos desejos dos filhos com deficiência foi apresentado nos discursos dos entrevistados das famílias 2 e 4, demarcando a forma como elas têm conduzido o cuidado. Já nas famílias 1 e 3, a estratégia de cuidado mais perceptível foi o respeito às limitações dos filhos, evitando exigir deles

\footnotetext{
49 "Na tentativa de minimizar a angústia de não conseguir dar conta da vida do filho, os pais podem delegar à outra instituição esse cuidado.” (MACEDO \& ROSA, 2010).
} 
comportamentos e conquistas para além de suas capacidades. Trechos de narrativas que sinalizam o respeito aos desejos dos filhos estão descritos abaixo:

Não adianta levá-la [levar a filha 2 para visitar parentes] para o desassossego dela. (...) Eu sei que ela não vai gostar, então para que eu vou levá-la? (Mãe 2)

Aí [o pai 4 pergunta]: 'vai dormir lá em casa?' [filho 4 responde em libras]: 'não, vou dormir com minha mãe.' [Resposta do pai 4]: 'então tá bom!' Eu não posso obrigar. (Pai 4).

[O Filho 2] largou a fono [fonoaudiologia] agora, depois de dez anos. (...) Eu falei: 'eu acho que ele tem que largar a fono, porque ELE quer largar a fono.' '(...) eu não tô achando que ele não tem mais que fazer fono, tô achando que ele tem que dar uma parada agora na fono, porque como a gente fica de saco cheio de fazer as coisas, quem disse que ele não tá? (...)'. Vou dar um tempinho pra ele. (Pai 4)

Luz \& Miranda (2010) incentivam esse respeito aos desejos dos sujeitos cuidados por considerarem essa atitude uma forma de cuidado ético, que respeita as vontades e supera o preconceito. Também para Tronto (1997), na ação de cuidar, é importante tratar o indivíduo da maneira como ele desejar, considerando suas necessidades específicas e concretas. Valorizar as escolhas dos filhos com deficiência pode ser um importante passo no sentido de reduzir o estigma, historicamente construído, de que pessoas nessa condição são incapazes de exercer sua cidadania (Oliveira, 2010).

Quanto ao respeito às limitações dos filhos com deficiência, há os seguintes relatos que melhor o retratam:

Porque o (Filho 3) é aquele negócio... Ele tem o time dele e isso aí a gente tem que compreender, né. (Pai 3)

É uma coisa que a gente tá até conversando com o centro de terapias lá. É... Ela La filha 1$]$ tem que fazer aquilo que ela tá pronta para fazer. A gente não vai buscar acelerar nenhum processo. A gente tem medo de acelerar alguma coisa e botar a perder um trabalho que já foi feito. (Mãe 1)

Impelir o filho com deficiência a buscar comportamentos que superam suas capacidades físicas ou intelectuais poderia ser uma ação associada à manutenção da fantasia do filho idealizado após a comprovação da deficiência. Trata-se de um processo de denegação, de recusa da realidade, identificado por Góes (2004) como 
um afeto vivenciado por algumas famílias de pessoas com deficiência. Pelos relatos acima, a denegação não parece ser uma realidade dos sujeitos da nossa pesquisa. Ao contrário, as famílias demonstram aceitar a condição do(a) filho(a); o que, segundo Cavalcante (2007), é o tipo de postura que, de fato, pode ajudálo(a).

Comportamentos e situações que podem ajudar o(a) filho(a) com deficiência a desenvolver-se dentro dos seus limites e potencialidades, e auxiliar as famílias a empreenderem um cuidar equilibrado - que não convive nem com o excesso e nem com a carência de zelo e atenção (Boff, 2011) - é o que estamos nomeando de contextos facilitadores do cuidado; e o seu oposto, chamamos de contextos dificultadores. Buscaremos, na seção seguinte, identificar quais desses contextos antagônicos ocorreram nas histórias de vida das famílias sujeitos da nossa pesquisa.

\subsection{3 Contextos Facilitadores e Dificultadores do Cuidado do(a) Filho(a) com Deficiência}

A consideração de que há contextos capazes de influenciar as famílias, a ponto de facilitar ou dificultar o cuidado dos filhos com deficiência, está ancorada em Bronfenbrenner (1996, Apud Oliveira, 2011), que concebe a família como um microssistema que recebe influências de outros sistemas, externos a ela.

Quando questionamos, ao fim das entrevistas, sobre quais contextos teriam funcionado como facilitadores do cuidado, obtivemos como respostas: a busca pelo conhecimento a respeito da deficiência do(a) filho(a) e as redes de apoio social.

O estudo acerca da deficiência foi citado pelas entrevistadas das famílias $1 \mathrm{e}$ 2. O enfoque que essas mães deram à busca pela instrução pode estar relacionado com os fatos de suas filhas possuírem Síndromes popularmente desconhecidas e que demandam entendimentos sobre suas características, a fim de que seja possível anteciparem-se aos problemas e compreenderem o que está ocorrendo quando os sintomas aparecerem. 
Ela [filha 1] não vai me dizer: 'mãe, eu tô com queimação aqui no esôfago. Tá me doendo a garganta'. A gente é que teve que se antecipar, ficar percebendo os sintomas para quando a coisa começar, identificar. Então, embora a criança não seja uma Síndrome, conhecer bem essa Sindrome [Síndrome de Rett], o que que ela pode trazer, e compreender o quanto isso vai ou não limitar a vida da criança, é importante, né. (Mãe 1)

Aí eu comecei a ler muito sobre essa Síndrome [Síndrome de Freeman-Sheldon] e (...) nos trabalhos que eu li apareciam 24 características que, nos estudos de caso, apareciam ou não. Quer dizer, ela [a filha 2] tem algumas e não tem outras. Tem umas [características] que são, basicamente, é... fisionômicas. Por exemplo (...) a orelha pequena; não, a orelha dela [da filha2] é normal. A mão é tortinha; sim, a mão [da filha 2] é tortinha... (Mãe 2)

Cavalcante (2003) corrobora a importância de famílias estudarem a respeito da deficiência do(a) filho(a). Segundo a autora, a construção de novo estoque de conhecimentos é um dos fatores que possibilita à família intervir na evolução global do(a) filho(a) com deficiência e caminhar no sentido de uma história de superação.

A rede de apoio social foi valorizada por todas as famílias sujeitos desta pesquisa, o que nos impele a considerá-la um forte contexto facilitador do processo de cuidado dos filhos; estando em consonância com o que afirma a literatura vigente (Bastos \& Deslandes, 2008; Sprovieri \& Júnior, 2001). Essa rede oferece apoio emocional, suporte de informação e suporte material. É formada por amigos, vizinhos, companheiros de igreja e familiares, distinguindose das lógicas de atenção prestadas pelo mercado e pelo Estado (Bastos \& Deslandes, 2008; Barbosa et al., 2009).

O suporte emocional, que é caracterizado pela amizade e demonstração de cuidado ou simpatia, ajudando a família a sentir-se mais confortada e amparada (Barbosa et al., 2009), foi registrado em relatos como o do pai 3 e mãe 2, que abordam sobre o apoio da vizinhança e de familiares, respectivamente:

Olha, por exemplo, lá no prédio onde nós moramos, todo mundo conhece o (Filho 3), né, e, de certa forma, ajuda. Só pelo fato de não ter restrições ou não demonstrar qualquer atitude antipática, ou qualquer coisa, já ajuda. (Pai 3)

Tinha também a tia da mamãe... quer dizer, era uma família muito afetuosa, que sempre dava muito carinho. (Mãe 2) 
O suporte emocional mais registrado pelos entrevistados, no entanto, foi o fornecido por outras famílias de pessoas com deficiência, o que parece ser justificado por uma concepção de que pessoas que vivenciam problemas semelhantes têm capacidades de compreender e ajudar uns aos outros.

A gente conseguiu um apoio psicológico melhor na família, e nas mães e nos pais de outras crianças com a mesma doença (...). Acho que se não tivesse esse contato com outras famílias, de referência para dar um telefonema em uma época que a gente tava mais angustiado, seria bem mais difícil. (Mãe 1)

Nós tivemos várias pessoas do nosso relacionamento. Quer dizer ${ }_{2}$ relacionamento com outros pais de excepcionais nos ajudou muito, né. (Pai 3)

Você acaba fazendo uma rede, né, do pessoal de UTI. Tem uma cumplicidade muito grande, tem coisas assim de sofrimento muito grande; e o sofrimento aproxima e ao mesmo também forma a solidariedade. (Pai 4)

Já o suporte de informação, que funciona quando uma pessoa ou instituição é fonte de conhecimento, ajudando a família a compreender o que está acontecendo com o filho e a acessar informações sobre a melhor maneira de cuidar dele (Barbosa et al., 2009), foi sinalizado pela mãe 1, ao referir-se a uma associação que presta informações sobre a Síndrome da filha.

E dentro do Brasil tem uma associação de Síndrome de Rett que fica em São Paulo. Quando a gente soube o diagnóstico da (Filha 1), a gente também marcou uma avaliação dela lá. A gente se associou a essa entidade, né, e a gente sempre que sente necessidade recorre a eles para alguma informação, alguma indicação, avaliação global. (Mãe 1)

A mãe 1 também destaca a importância do suporte de informação que obtém via redes sociais da internet. As informações são postadas por pessoas que também têm filhas com Síndrome de Rett, o que nos permite reiterar a tendência de as famílias valorizarem o apoio prestado por quem vivencia problemas semelhantes.

E o que a gente tira bastante proveito também é de facebook. Por incrivel que pareça [risos]. Tem algumas comunidades sobre Síndrome de Rett, de outros países que a gente entrou. E tem também um grupo que formou há pouco tempo. Um grupo de pais aqui do Brasil. Então ali a gente sempre conversa alguma coisa, né: 'Ah, alguém já deu o medicamento tal pra sua filha?' 'Preciso de um neurologista na cidade tal...'Então ali a gente troca informações, né, e de uma 
maneira mais aberta e tal. E algumas informações que a gente vê ali são bem úteis, né. Às vezes uma frase que uma mãe coloca, dá um estalo: 'opa, pode ser isso!' E ali a gente vai investigando e fazendo perguntas mais especificas e tal. Então, as redes sociais hoje, pra nós, elas são bem importantes. E a gente descobriu algumas instituições na internet, núcleos de referência de pesquisa e acompanhamento dessa Síndrome de Rett. (Mãe 1)

Quanto ao(s) prestador(es) de suporte material, caracterizado pela provisão e oferecimento de recursos materiais e financeiros - considerado por Barbosa et al. (2009) como fundamental para que as famílias consigam atender às demandas de cuidado impostas pela condição do filho -, não foram sinalizados os sujeitos que comumente compõem a rede de suporte social, mas sim o benefício de saúde prestado pela empresa, a qual os entrevistados estão vinculados. Trata-se de um programa corporativo que disponibiliza recursos para a prestação de assistência especializada em habilitação, reabilitação e educação para pessoas com deficiências ou transtornos.

\begin{abstract}
Ah, a (empresa) paga a escola, então já é... Porque se eu tivesse que pagar a casa [moradia assistida] e a escola, ia ficar muito difícil. A (Empresa) pagando a escola, já me ajuda muitíssimo. (Mãe 2)
\end{abstract}

Então a gente acha que ter o plano [benefício empresarial] é um negócio fora de série, porque o desconto que a gente tem de livre escolha [reembolso das despesas com os tratamentos e escolas do filho 3], né, é muito menor. (Pai 3)

O pai 4 sinaliza outra forma de suporte financeiro da empresa, nomeada de processo de excepcionalidade, que o auxilia em eventuais despesas de tratamentos do filho que não estão contempladas no rol de coberturas do plano de autogestão em saúde.

A (empresa) me ajudou pra caramba. A (empresa) tem um programa de excepcionalidade (...) Eu fui tecnicamente pedir uma coisa que a companhia fornece; fiz todo o processo e ele [Gerente] me forneceu. (...). Ano passado retomei esse processo de excepcionalidade; precisei, retomei (...). (Pai 4)

A mãe 1 concebe que tanto por esse suporte material da empresa, quanto pelo fato de que ela e o marido exercem atividades remuneradas, a sua família não teve necessidade de buscar apoio financeiro em outras fontes da sociedade para a cobertura das despesas com a filha: "Como a gente tem o benefício do programa e 
são duas pessoas que trabalham fora, então a gente não teve ainda a necessidade de buscar um apoio financeiro (Mãe 1).

Esse trecho da narrativa da mãe 1 permite-nos resgatar a distinção entre famílias capazes e incapazes propostas por Mioto (2006). As percebidas como capazes, na sociedade brasileira, são aquelas que, tal como a família 1, conseguem desempenhar com êxito as funções de proteção que lhe são esperadas, sem necessidade de recorrer a recursos do Estado.

Percebemos que essa noção de capacidade familiar está relacionada com todas as famílias sujeitos da nossa pesquisa, uma vez que elas compõem as camadas média e de elite da população brasileira; como tal, não vivenciam situações de vulnerabilidade extrema, tendendo a ser excluídas ou a excluírem-se do acesso a políticas sociais (Mioto, 2006; Carvalho, 2005). As consequências são os custos elevados de reprodução assumidos por essas famílias (Bilac, 1995) e a desresponsabilização do Estado do seu papel de proteção social, que deveria ser garantido a todos os cidadãos (Carvalho, 2005).

Quando as famílias sujeitos da nossa pesquisa vivenciam momentos críticos, tendem a buscar alternativas para fora das políticas de assistência do Estado, tal como fez o pai 4 ao recorrer ao programa de excepcionalidade prestado pela empresa em que trabalha, quando se viu sem condições financeiras de custear as despesas do filho. Dessa forma, tendemos a supor que o apoio financeiro da empresa foi um fator que contribuiu para que os entrevistados não citassem a ausência de proteção estatal como um contexto dificultador do cuidado dos filhos.

As narrativas dos entrevistados demonstraram que os contextos dificultadores do cuidado familiar são: o despreparo de algumas instituições escolares e de profissionais de saúde para lidar com as necessidades específicas dos filhos; e a discriminação dirigida às pessoas com deficiência.

O despreparo de instituições e profissionais para lidar com as necessidades da criança ou do adulto com deficiência parece estar associado ao medo de responsabilizarem-se pelo cuidado dessa pessoa; é o que relata a mãe 1, em relação à sua experiência com a escola da filha:

Com três anos foi um outro marco (...) o fantasma da epilepsia que assusta qualquer escola; qualquer escola que você chegar e falar: 'minha filha tem epilepsia', eles vão se arrepiar. Se falar que eventualmente pode precisar fazer uso de diazepam retal, então, a escola... tem escola que pira né... Foi o que aconteceu 
com ela. Onde (Filha 1) tava [estudando], a neurologista precisou ligar e falar: 'olha só, ela por enquanto não tem crises epiléticas que são severas, né, ela tá controlada com medicação. E se precisar fazer uso de diazepam, ela vai precisar fazer uso de diazepam na escola, não tem tempo de chamar o pai e a mãe para fazer'. Então, foi uma época que foi um pouco estressante na escola. (...) Então, até a própria Psicóloga da escola dizia: 'imagina, fazer uso de medicação retal na criança. Isso é uma agressão para a criança!' E não havia o que tirar isso da cabeça daquela Psicóloga. Eu dizia: 'olha, na convulsão ela não sabe nem que ela existe. Ela ta numa crise convulsiva, ela tá fora do planeta'. Então... Foi difícil. Teve um estresse com a escola naquela época. (Mãe 1)

O Pai 3, ao longo da narrativa sobre os diversos tratamentos e escolas pelas quais o filho passou, também critica práticas e condutas de certas instituições e profissionais, revelando a dificuldade de encontrar mão de obra especializada que se dedique à especificidade da deficiência:

A gente tem muito medo dessa tal de escola que na verdade é um depósito. (...) Existem muitas, a gente olha e diz: 'ih, isso ai é estilo depósito'. Por exemplo, quer ver, lá na... a (Mãe 3) viu que lá tem muita enganação também. Você fala com o Coordenador e o Coordenador não coordena nada... (Pai 3)

Quer dizer, precisa ter aquele espírito para tratar com aquele tipo de, de, de criança e mesmo de adulto, né, com necessidades especiais. É muito difícil de encontrar mão de obra pra fazer esse trabalho com dedicação, né. Então a gente sente essa dificuldade. (Pai 3)

Machado \& Scramin (2002), na condição de pessoas com deficiência e de pesquisadoras da área, corroboram a afirmação das famílias 1 e 3 de que há despreparo de muitos profissionais para o atendimento às necessidades específicas dos deficientes. Autores como Martines \& Machado (2010) contribuem para a discussão sobre o cuidado profissional em saúde, alertando para a necessidade de não darem uma única direção ao trabalho desenvolvido, pois é necessário respeitar os desejos singulares dos sujeitos cuidados.

A discriminação dirigida às pessoas com deficiência foi um tema que motivou o discurso dos entrevistados das famílias 2, 3 e 4. Eles revelam terem vivido maiores situações de preconceito na infância dos filhos com deficiência, conforme relatos a seguir:

[Na infância do filho], de vez em quando, tinha a curiosidade: [pessoas perguntando] 'ah, ele é doente, é?' [resposta dos pais]: 'não, tem nada disso não, ele é igual a todo mundo!'. (Pai 3) 
Eu só senti [a discriminação] uma vez que a gente foi a uma festa que o (Filho 4) era pequeninho, ai um pai falou assim: 'ah, não adianta vocês ficarem brincando com ele não, porque ele não escuta.' Ai eu olhei, quase que eu falei assim: 'cara, tu é um...' 'Eu vou evitar xingar aqui, a gente ta numa entrevista oficial (risos). (Pai 4)

As duas situações, acima descritas, a associação da deficiência a uma doença e a correlação da deficiência auditiva à impossibilidade de convívio social parecem revelar a tendência de atribuírem aos sujeitos com deficiência desvantagens ainda maiores que as de fato, eles possuem. Suportamos essa análise em Goffman (2008), pois o autor esclarece que os indivíduos detentores de um estigma - uma característica diferente do que é socialmente previsto como normal - não são considerados completamente humanos; e, com base nessa percepção, sofrem vários tipos de discriminações. Segundo o autor, os não estigmatizados, ou normais, tendem a inferir uma série de imperfeições ao indivíduo com um estigma, a partir da sua imperfeição original; é por esse motivo que alguns generalizam a deficiência de visão para uma gama de incapacidades, de tal modo que gritam com um cego como se ele não pudesse ouvir, ou tentam erguê-lo como se não pudesse andar.

Outros relatos dos pais parecem revelar, entretanto, que, nos dias atuais, as pessoas estão melhores informadas e a inclusão social ${ }^{50}$ da pessoa com deficiência está se afirmando no Brasil:

Mas hoje em dia a inclusão é uma realidade e essa parte [discriminação] está sendo superada. (Pai 3)

A deficiência hoje tá mais exposta. As pessoas com necessidades especiais estão mais expostas, estão mais nas ruas, atuantes. Antigamente, um cadeirante não ia pra rua, ficava em casa. Hoje ele tá correndo na São Silvestre. (...) A gente fala tanto dos gays saírem do armário, a gente tá tirando nossas crianças [pessoas com deficiência] também do armário que a gente colocou. Não tenho vergonha de andar com o (filho 4) na rua. A (Mãe 4) também não tem vergonha de andar com $o$ (Filho 4) na rua. (Pai 4)

50 "Como filosofia, incluir é a crença de que todos têm direito de participar ativamente da sociedade, contribuindo de alguma forma para o seu desenvolvimento". (WERNECK, 2009, p. 42) 
Werneck (2009) é uma das autoras que enaltece a inclusão social. Segundo a autora, "a inclusão vem para quebrar barreiras cristalizadas em torno de grupos estigmatizados. Indivíduos marginalizados terão a oportunidade de mostrar seus talentos.” (p. 42). Conforme postulado por Werneck (2009), quando o processo de inclusão de uma pessoa com deficiência ocorre, e é bem conduzido, os benefícios são amplos: amizades se desenvolvem; pessoas sem deficiência aprendem a apreciar as diferenças e exercitam-se na construção de sua cidadania; e aquelas com deficiência tornam-se mais motivadas. Assim, a inclusão representa um ganho para todos.

Talvez a atual tendência à inclusão social das pessoas com deficiência seja o motivo pelo qual a mãe 1, que possui a filha mais nova dentre os entrevistados, não tenha citado o preconceito como um problema a ser enfrentado por sua família. Entretanto, os demais entrevistados, embora observem melhorias nesse aspecto, informam ainda passarem por situações de discriminação, tanto no âmbito familiar quanto no espaço comunitário. E, possivelmente, por terem tomado como verdade o fundamento da inclusão social, esses pais afirmam não ficarem passivos a tais situações, empreendendo esforços para garantir a seus filhos o direito a viver sem serem discriminados.

Quer dizer, na minha família nunca houve [discriminação]... Quer dizer, tem um cunhado meu que de vez em quando fica... não é nem tirando sarro, mas é falando algumas coisas para o (Filho 3) que o (Filho 3) fica irritado. Já falei para ele: 'oh, vamos parar com isso'. (Pai 3)

[Fala de alguém sobre o filho 4]: 'Ah, tadinho'. Quando alguém fala assim, eu pergunto: 'tadinho por quê?' [resposta da pessoa]: 'ah, porque ele não escuta'. (Pai 4): 'não é tadinho, não. Olha só, conversa com ele. Fala com ele olhando para ele. 'Ai [a pessoa] começa a falar e ele [filho 4] começa a responder. [fala da pessoa]: 'ele tá fazendo um sinal'. [Pai 4 explica]: 'esse sinal que ele tá fazendo, é que ele tá conversando com você, [dizendo] que tá legal, não sei o que.' Ou seja, depende como você lida com isso. (Pai 4)

Você tem que mostrar para a sociedade que ela [filha com deficiência] é uma pessoa e que precisa ser respeitada, sabe. Então, por exemplo, ah, não vou levar meu filho não sei aonde, porque não sei o que... Não, tem que levar sim! E as pessoas têm que entender que ela é uma cidadã da sociedade. Nem sempre eu convivo com quem eu quero na sociedade. Então, por que eu vou restringir a minha filha de estar na sociedade? (Mãe 2) 
Por ser a família, o primeiro espaço de interação dos seres humanos em desenvolvimento, com forte influência em seus padrões de comportamento (Bronfenbrenner, 1996), consideramos que o modo como as famílias lidam com seus filhos com deficiência, incluindo a postura que assumem perante a discriminação social, terão influências no comportamento e desenvolvimento desses filhos. Certas consequências das atitudes das famílias, quanto aos cuidados das pessoas com deficiência, bem como as implicações da deficiência do(a) filho(a) para os integrantes da sua família, serão melhores abordadas na seção seguinte.

\section{6 \\ Implicações da Deficiência do(a) Filho(a) para os Integrantes das Famílias Sujeitos da Pesquisa}

A literatura específica (Sprovieri \& Junior, 2001; Petean \& Murata, 2000) afirma que a deficiência do(a) filho(a) traz consequências para a família, pois altera a dinâmica familiar, provocando reestruturações nas vidas de cada um dos seus membros. Há famílias que conseguem construir uma dinâmica acolhedora, criativa e positivada, proporcionando à pessoa com deficiência, um ambiente que lhe favoreça o desenvolvimento (Cavalcante, 2003; Sprovieri \& Junior, 2001; Barbosa et al., 2009). Entretanto, algumas famílias apresentam consequências consideradas por Sprovieri \& Junior (2001) como negativas, dentre elas: dificuldade na promoção da saúde emocional dos membros do grupo; prejuízos na interação social; dificuldade na interação conjugal; e construção de vida em função do filho, por sua dificuldade de adquirir autonomia.

Por meio das narrativas das famílias sujeitos da nossa pesquisa, identificamos que os processos de (re)organização das famílias, a partir da constatação da deficiência do(a) filho(a), geraram implicações para pais e mães; para os irmãos; e para a própria pessoa com deficiência. Daremos enfoque às implicações que refletem em suas vidas nos dias atuais e que estão relacionadas aos cuidados dos filhos. 
Quanto aos pais e mães, foram identificadas consequências divergentes em relação ao quesito viver em função do filho. A família 1 foi a única que apresentou relato sobre o grande tempo de dedicação ao cuidado da filha com deficiência, o que nos permite supor que esse fato ocorre de maneira mais significativa nesta família que nas demais. O casal depende do apoio de familiares para conseguir desviar a atenção focada na filha e participar de atividades de lazer; apoio este que não ocorre de forma rotineira. Segue relato da mãe acerca dessa constatação:

Quando tem esse apoio [dos familiares] para, como a gente diz, fazer um plantão, que é dormir com ela [com a filhal], pra gente é ótimo né. É o momento da gente sair, ir para algum lugar, o que hoje é cada vez mais esporádico. Então, é uma beleza, mas a gente não procura se basear por isso. Mesmo porque você não pode forçar a família a viver um dia a dia que é teu, né. (Mãe 1)

O relato, abaixo, que aborda sobre a vida social dos pais 1 , antes da filha com deficiência, confirma que o atual tempo de dedicação à criança é uma consequência relevante para essa família. "[Antes da filha 1] a gente tinha uma vida social normal. Saia com os amigos, ia à praia... Final de semana dançava bastante, viajava..." (Mãe 1).

A intensa dedicação à filha com deficiência, que acarreta redução do tempo destinado ao lazer dos pais, pode dificultar a saúde emocional e social do casal; consequências consideradas por Sprovieri \& Junior (2001) como negativas para a família. Consideramos que essa maior dedicação da família 1 seja justificada pelo fato de a filha ser criança e, como tal, exigir ainda mais atenção familiar, não apenas pela sua deficiência, mas também pelas demandas de cuidado necessárias à sua condição etária. Os demais filhos das famílias sujeitos da nossa pesquisa, embora tenham demandas específicas de cuidados, já passaram por maiores estímulos terapêuticos que a filha 1, e suas famílias tiveram maior tempo para reorganizar-se após a constatação das deficiências.

A família 4 diverge da 1 no aspecto 'viver em função do fillho', ao relatar ter criado mecanismos de organização interna para que a vida do pai e da mãe não se voltasse, excessivamente, para o cuidado do filho com deficiência. Cabe ressaltar, entretanto, que a (re)organização de vida da mãe 4, no que se refere à dedicação ao filho, foi revelada pelo ex-marido, que não possui completo acesso a 
informações sobre sua rotina. "Hoje [o dia a dia do pai e da mãe] tá organizado, sim, em torno do (Filho 4), mas sem perder as nossas vidas. A gente continua vivendo, né. Eu retomei outra relação. A (Mãe 4), eu não sei porque ela não fala comigo sobre isso" (Pai $4)$.

A justificativa para a separação dos casais, que ocorreu nas famílias 2 e 4, foi dissociada da condição de deficiência dos filhos; conforme relatos dos entrevistados, descritos a seguir:

[Dissolução da união teve relação com a deficiência da filha?] Não, não teve não! Não teve nada a ver. (Mãe 2)

Ela [a mãe 4] (...) me mandou uma reportagem com uma pesquisa: $83 \%$ dos casais que têm filhos especiais se separam. Eu falei: 'não sei por que isso, mas deve ter algum sentido. (...) O homem não consegue suportar a carga?' Mas não foi por isso [que o pai 4 se separou]. Eu não separei da (Mãe 4) por causa do (Filho 4), eu me separei... do (Filho 4) por causa da (Mãe 4), vamos dizer assim. É diferente! (Pai 4)

Diante do exposto pelos entrevistados, não podemos vincular seus divórcios ao que Sprovieri \& Junior (2001) consideram como mais uma consequência negativa da deficiência de um filho: o prejuízo na relação conjugal. A dissolução do laço conjugal é uma realidade crescente na sociedade contemporânea. É geralmente orientada pela dimensão do afeto - independente da existência de um filho com deficiência - e serve como indício da crise da sociedade patriarcal (Casttels, 2000). O crescente número de divórcios nas camadas médias da população brasileira guarda explicações, de acordo com a literatura, na maior escolarização das mulheres e na incorporação dessas no mercado de trabalho, já que dispor de dinheiro e controle sobre ele pode dar maior poder de escolha quanto a manter ou romper uma relação conjugal (Bilac, 1995; Arriagada, 2006). De fato, a alta escolarização das mães 2 e 4 e suas inserções no mercado de trabalho são características dessas famílias, que passaram pelo processo de separação. Não se trata, entretanto, de fatores determinantes; a exemplo da mãe 1, que apesar de também estar nessas condições, mantém sua relação conjugal.

A mãe da família 3 é a única, dentre as demais da nossa pesquisa, que não está inserida em atividade de trabalho remunerada, o que pensamos ser possível considerar como uma das implicações da deficiência do filho, quando focamos no 
aspecto do cuidado. Ela optou por dedicar-se ao filho com deficiência, pelas maiores demandas de cuidado que sua condição apresenta; conforme relatado pelo entrevistado:

O cuidado [de um filho com deficiência] tem que ser maior. Por exemplo, a (Mãe 3) teve que se dedicar mais a ele [filho 3], então sempre há [alguma restrição para a família quando possui um filho com deficiência]. Houve sim! Mas nada que não fosse... Que tornasse impossivel. (Pai 3)

O fato de ter sido a mãe a deixar de exercer o trabalho extralar para dedicarse ao filho com deficiência está em consonância com o que foi constatado por Almeida (2011): as mulheres, por serem as principais cuidadoras da família, são as que mais modificam planos individuais com a chegada de um filho. Elas podem mudar de profissão, deixar de trabalhar ou diminuir a carga horária de trabalho; sobretudo se tiverem um filho com deficiência.

As pessoas com deficiência das famílias 1 e 4 são filhos únicos. Já as famílias 2 e 3, tiveram outros filhos, não deficientes. Na pesquisa de campo, questionamos se os entrevistados perceberam implicações da deficiência para as vidas desses irmãos; obtivemos algumas respostas que coadunam e outras que divergem da literatura específica (Lobato, 1983; Simeonsson \& Mchale, 1981).

O irmão 2 é alguns anos mais velho que a irmã com deficiência e, na infância, apresentou dificuldade de aceitá-la, mantendo-se distante. A aproximação deles deu-se por intermédio de ajuda terapêutica.

[Na infância,] ele [irmão 2] nunca brincava com ela. Ele nunca ficava com ela. Eu via que os outros meninos brincavam com a (Filha 2). Ele sempre ficava assim meio afastado... É, deve ter sido um impacto, ele era um menino que pegava surfe tudo; devia ter algum comprometimento (...). (Mãe 2)

Por uns três anos, ele [irmão 2] fez terapia. Ele começou a aceitar mais, sabe. Depois de algum tempo (...), eu me lembro de que ele já interagia bem. (...) Hoje em dia, ele gosta muito dela, mas foi um aprendizado. (...) Mas ele foi para a terapia, fez a terapia, acho que foi muito bom para ele aprender a lidar com ela. (Mãe 2)

A necessidade de suporte psicológico, que pode ser apresentado por irmãos de pessoas com deficiência, é observada por Lobato (1983). Para o autor, a explicação pode estar na sobrecarga de responsabilidades atribuídas a eles e na 
menor atenção recebida dos pais. Não foi verificada, na narrativa da mãe, uma sobrecarga de atribuições ao irmão 2 . Porém, podemos inferir a possibilidade de uma menor atenção na infância, já que os primeiros anos de vida da filha com deficiência demandaram extremas necessidades de cuidados a ela, sendo considerado pela entrevistada um período muito difícil. Segue trecho de narrativa que aborda sobre as dificuldades encontradas nos primeiros anos de vida da filha 2, por meio do qual supomos uma menor dedicação ao filho não deficiente:

O fêmur dela [filha 2] não se encaixava naquele osso da bacia, então (...) ele [Ortopedista] colocou-a num aparelho ortopédico (...). Ou seja, nessa fase, ela só mexia os bracinhos, a cabeça e do joelho para baixo. (...) Aí realmente ficou muito difícil porque eu não podia dar banho, por causa do aparelho (...). Então ela chorava, a gente não sabia o que fazer muito e dava banho de algodão... Então, foi muito difícil, né. (...) uma das características da Síndrome é o que ele chama espasmo do piloro. Que é uma válvula que tem aqui no estômago e que, por nada ela abre e a criança vomita tudo. Então, às vezes, ela vomitava; acabava de mamar, ela vomitava tudo. (...) A gente tentava tudo para ela não vomitar, só que era uma coisa involuntária. (...) Aí depois tinha que dar mamar tudo de novo porque ela tinha fome (...). Então quer dizer, (...) foi muito difícil. (...) Aí depois, ele [Ortopedista] tirou aquele aparelho e colocou uma fralda ortopédica. Então aí ela já mexia daqui para cima. Mas essa parte aqui [parte de baixo], ela ficou imobilizada. (Mãe 2)

Também consideramos possível deduzir que o distanciamento do irmão $2 \mathrm{e}$ a sua tendência de evitar brincar com a irmã em espaços públicos, talvez possam ser explicados pelo sentimento de vergonha; uma vez que a representação da deficiência desvaloriza a família perante a sociedade (Sprovieri \& Junior, 2001).

$\mathrm{Na}$ família 3, há duas irmãs mais novas que o filho com deficiência. O pai 3 afirma que o menino demandava maior atenção em relação aos demais integrantes da família. Entretanto, o entrevistado não identificou insatisfação ou incompreensão das meninas.

Então, lá em casa, felizmente, né, quer dizer, minhas duas filhas compreendem o problema, dão apoio e ajudam a gente. (...) Elas não se queixavam. Mas claro que a gente sempre educou dizendo que o (Filho 3) precisava de um pouco mais de atenção. Mas elas viam também, né. Elas viam que ele tinha problemas, esse negócio todo, então nunca houve assim grandes disputas. Nunca houve. Felizmente, né! Quer dizer, das meninas [irmãs do filho 3] não tenho queixa alguma. De jeito nenhum. (Pai 3) 
Por meio do trecho de narrativa supracitado, consideramos que a história da família 3 refuta a afirmativa de Simeonsson \& McHale (1981), de que o maior tempo exigido e gasto pelos pais com a criança com deficiência gera ressentimentos nos irmãos 'normais'. Embora os autores tenham chegado a essa conclusão por meio de suas pesquisas, a família 3 da nossa investigação demonstra não se tratar da representação da totalidade.

Os entrevistados das famílias 2, 3, e 4 demonstraram-se entusiasmados ao revelarem que as implicações atuais da deficiência para os próprios filhos deficientes voltam-se para conquistas e superações. Os filhos desenvolveram-se física, social e intelectualmente, dentro de suas possibilidades individuais; alcançaram o maior grau de autonomia possível para as suas condições; e vêm participando de espaços sociais diversos. Seguem os relatos que abordam acerca dessas considerações:

Ela [filha 2] tá muito bem! Eu acho que ela é uma pessoa entrosada na sociedade. A casa [moradia assistida] deu uma independência e uma liberdade a ela muito grande. (Mãe 2)

Ele [filho 3] tem um problema de retardo mental, mas ele tá alfabetizado, ele escreve e sabe ler tudo quanto é coisa, ele tem a sensibilidade dele - toque e esse negócio todo - preservado, tem um ouvido excepcional; ele gosta de negócio de música. Ele tem dificuldade para cantar. Mas ele percebe as coisas, ele saca as coisas (...). $O$ (Filho 3) é autônomo. Ele vai ao banheiro sozinho, ele faz as necessidades dele sozinho, não tem que usar fralda; nada disso. Ele é autônomo! Toma banho sozinho, faz as coisas dele sozinho. E quando há necessidade, a gente dá assistência. Mas $99 \%$ de tudo ele faz sozinho. (Pai 3)

(Filho 4) me surpreende, porque ele reverteu as coisas. (...) Eu me considero uma pessoa forte, também, mas não sei de onde ele tira aquela força dele. (...) Toma banho sozinho, se arruma sozinho, faz tudo sozinho, liga o computador, liga a televisão, abre a geladeira, tira o que quer, ou seja, é uma pessoa independente pra caramba; forte mesmo. E eu vejo isso com as coisas dele. Ninguém precisou ensinar o computador pra ele, ele mexe sozinho, faz tudo sozinho, é muito engraçado. (Pai 4)

A pouca idade da filha 1 e a tendência de progressão da sua deficiência, talvez possam explicar o fato de sua mãe não citar conquistas da criança com o mesmo entusiasmo dos demais entrevistados. Todavia, não se pode perder de vista que os esforços desta família e o investimento em apoios profissionais e sociais diversos têm permitido respostas favoráveis, quanto a limitar a progressão da deficiência da filha 1. "A gente vai tateando por isso para ver se ela tá indo bem 
ou não. (...). E a resposta dela mostrou pra gente que a gente tá indo no caminho certo, que realmente é isso ai'” (Mãe 1).

Podemos associar essas conquistas dos filhos com deficiência - aqui consideradas como implicações do cuidado familiar - com o que Cavalcante (2003) nomeia de histórias de sucesso. Segundo a autora, tais histórias familiares são traçadas pelas seguintes características: famílias inclusivas - que acolhem a diferença e favorecem a participação do(a) filho(a) em diversos espaços sociais, de acordo com suas possibilidades; famílias que valorizam a vida - que enxergam além da deficiência e encontram formas criativas de conviver com o(a) filho(a); e famílias que investem em apoios sociais diversos.

As características citadas por Cavalcante (2003) guardam fortes semelhanças com as famílias da nossa pesquisa. Dessa forma, entendemos ser possível considerar que, apesar das dificuldades enfrentadas, essas famílias vêm caminhando no sentido de possibilitar um ambiente facilitador para o desenvolvimento do(a) filho(a) com deficiência. 


\section{4 \\ Considerações Finais}

As categorias 'família' e 'cuidado' estão intrinsecamente relacionadas, uma vez que as famílias configuram-se como as principais responsáveis pelo cuidado e proteção dos seus membros. Os comportamentos familiares associados às atividades de cuidado são variáveis, já que cada família constrói sua própria dinâmica; influenciada por contextos ideológicos, políticos e psicológicos. As dinâmicas familiares são, portanto, construídas e negociadas por influências internas, advindas dos seus próprios integrantes, e por diversas influências externas, incluindo as instituições sociais.

Um mesmo sistema familiar vivencia várias mudanças ao longo de sua existência, o que demanda processos de (re)organização constantes na sua dinâmica. Algumas mudanças são previsíveis e, embora deflagrem reordenamento dos comportamentos das famílias, tendem a ser enfrentadas com maior tranquilidade. Outras, entretanto, são inesperadas. Essas acarretam maiores crises, na medida em que deflagram estresse e resultam em processos de (re)organização mais significativos para o sistema familiar e para a vida de cada um dos seus membros.

A constatação da deficiência do(a) filho(a) pode ser deflagradora de maiores crises, já que distancia a família do modelo socialmente pré-concebido de família ideal. Nesse modelo, os filhos do casal possuem capacidades físicas, sensoriais, intelectuais e sociais compatíveis com o esperado para sua idade cronológica. Um filho com deficiência faz, portanto, sua família divergir do modelo esperado, levando pais e mães a vivenciarem sentimentos associados ao luto pela perda do filho idealizado.

Com o passar do tempo, as famílias buscam meios de adaptação às condições do(a) filho(a) com deficiência, criando mecanismos para atender às necessidades específicas de cuidado dessa pessoa. Tais processos de (re)organização das famílias são facilitados e dificultados por contextos intra e extralar, e trazem implicações para o sistema familiar como um todo e para seus integrantes individualmente. Os processos de (re)organização, a depender de 
como ocorrem, podem implicar em contribuições ou em prejuízos para o desenvolvimento da pessoa com deficiência e para a saúde emocional e social dos demais integrantes da família.

A presente pesquisa possibilitou uma aproximação dos processos de (re)organização de quatro famílias, a partir da constatação da deficiência do(a) filho(a), em particular no que se refere ao cuidado da prole. As narrativas dos pais e mães entrevistados também possibilitaram o conhecimento de implicações da deficiência do(a) filho(a) para os integrantes das famílias, bem como a identificação dos cuidadores das pessoas com deficiência e dos contextos facilitadores e dificultadores do cuidado familiar.

Os dados coletados na pesquisa de campo demonstram que, nas famílias sujeitos da nossa pesquisa, as mulheres são as principais cuidadoras dos filhos com deficiência. Todas contaram com o apoio de outra mulher, seja familiar ou profissional contratada, para o exercício do cuidado do(a) filho(a) com deficiência, contrastando com a reduzida participação dos pais.

Na família pertencente à geração mais jovem há, entretanto, maior igualdade na divisão de tarefas de gênero relacionadas ao cuidar da filha com deficiência, já que o pai participa ativamente do cuidado da criança. Já nas famílias de gerações mais antigas, reitera-se a primordial presença do gênero feminino no exercício do cuidado dos filhos. Destaca-se, em todas as famílias pesquisadas, o gerenciamento do cuidado como tarefa das mães, o que nos possibilita afirmar que, embora em algumas famílias haja maior participação paterna no cuidado dos filhos, ainda trata-se de um papel secundário ao das mulheres.

Alguns elementos levantados na pesquisa de campo revelam-nos maior flexibilidade dos tradicionais modelos que separam o masculino do feminino, dentre eles: o envolvimento de pais/homens no cuidado dos filhos, ainda que de formas secundária e mais centrada nas atividades referentes ao mundo externo à casa; as demonstrações orgulhosas de afetividade paterna; e a percepção dos homens entrevistados de que a responsabilidade pelas decisões concernentes aos tratamentos dos filhos com deficiência também deveriam competir a eles.

Dessa forma, no que se refere às relações de gênero, nossos entrevistados nos permitem supor que entre indivíduos das classes média e de elite da população brasileira, com alto nível de instrução, podem ser verificadas rupturas e continuidades no tradicional modelo de divisão de papéis de gênero. 
A seleção dos entrevistados, demarcada pelo recorte em dois homens e duas mulheres, possibilitou-nos conhecer histórias de famílias, a partir de percepções de gêneros distintos. Nas narrativas dos homens, destacam-se as percepções de que o cuidado do(a) filho(a) também é uma atribuição masculina e que a profissão ou formação das mulheres justifica sua maior capacidade de gerenciamento desse cuidado. Nas narrativas das mulheres, sobressai-se a valorização do apoio de outras cuidadoras - sem o qual não seria possível manterem-se no mercado de trabalho - e uma autoavaliação 'heroica', percebendo-se como ser de capacidade natural e ilimitada para amar e cuidar da prole.

Nas famílias pesquisadas, os processos de (re)organização a partir da constatação da deficiência do(a) filho(a), no que se refere ao cuidado da prole, têm como elemento coincidente a inserção das pessoas com deficiência em diversos apoios continuados de profissionais e instituições especializadas nas áreas de reabilitação e educação. Todos os entrevistados narram a busca incessante das famílias pelo que julgavam o melhor atendimento às necessidades específicas do(a) filho(a) com deficiência, tanto no âmbito interno, quanto no espaço extralar. Os cuidados familiares organizaram-se a partir do respeito aos desejos e às limitações dos filhos com deficiência, o que demonstra um movimento no sentido de superação da fantasia do filho idealizado.

O contexto unanimemente valorizado como facilitador do cuidado do(a) filho(a) foi a rede de apoio social, com destaque para o suporte emocional prestado por amigos, familiares e, sobretudo, por outras famílias de pessoas com deficiência - que também oferecem suporte de informação.

O suporte material citado pelos entrevistados não advém de familiares, amigos, companheiros de igreja e vizinhos - pessoas que compõem as redes mais comuns de apoio às famílias. Tal suporte é buscado nos benefícios prestados pela empresa a que essas famílias estão vinculadas. Embora em momentos críticos, tais famílias não contem com políticas sociais para o atendimento às necessidades de cuidado do(a) filho(a) com deficiência, a ausência de proteção Estatal não é sinalizada pelos entrevistados como um contexto dificultador. Constitui terreno fértil para futuras pesquisas a análise das consequências da (des)responsabilização do Estado pela proteção de famílias com menores possibilidades de arcar com os custos de reprodução dos seus filhos deficientes. 
O contexto dificultador do cuidado familiar mais sinalizado pelos entrevistados foi a discriminação dirigida às pessoas com deficiência. A esse respeito, as narrativas permitem-nos averiguar a permanência do preconceito oriundo do histórico estigma de anormalidade, mas também possibilita-nos perceber avanços no processo de inclusão social das pessoas com deficiência.

As implicações da deficiência para as famílias foram narradas de formas divergentes pelos entrevistados, sobretudo no que se refere ao quesito 'viver em função das necessidades do(a) filho(a)', já que uma das famílias demonstra intensa dedicação - que resulta em comprometimentos no lazer e na interação social - e outra relata uma organização familiar não voltada apenas para as necessidades do filho. As implicações para as vidas das mães também foram apresentadas de formas divergentes, com destaque para a saída de uma dessas mulheres do mercado de trabalho. As implicações para os irmãos relacionam-se com a maior atenção dos pais aos filhos com deficiência; a esse respeito, as meninas apresentaram maior compreensão e menor dificuldade de relacionar-se com o irmão com deficiência. Essa constatação conduz-nos a questionar se a dimensão de gênero influencia a fratria, a ponto de meninas assumirem posturas distintas às dos meninos em relação a irmãos com deficiência. Tal questionamento pode configurar-se em campo de interesse para futuras investigações.

As implicações para os filhos com deficiência apresentaram-se em relatos sobre limites à progressão da deficiência, conquistas de autonomia para atividades de vida diária e superação de certas limitações. Identificamos a necessidade de que estudos futuros aprofundem as implicações da deficiência do(a) filho(a) para os pais/homens, por tratar-se de uma lacuna da literatura vigente, que também não pôde ser desenvolvida nesta pesquisa. Também nos parece pertinente sugerir que futuros projetos debrucem-se sobre o conhecimento das implicações da deficiência para demais integrantes do grupo familiar que não possuem laços consanguíneos com o(a) filho(a) com deficiência, tais como os padrastos, madrastas e irmãos não biológicos.

Vários são os resultados encontrados e questões suscitadas quando nos aventuramos a investigar acerca dos cuidados de pessoas com deficiência por suas famílias. Esperamos que esta pesquisa tenha fornecido elementos mínimos de incentivo a novos estudos acerca das categorias 'deficiência', 'famílias' e 
'cuidado', sobretudo para o campo de investigação do Serviço Social brasileiro contemporâneo, onde tais temáticas apresentam-se pouco frequentes. 


\section{5 \\ Referências Bibliográficas}

ALMEIDA, A. Notas sobre a família no Brasil. In: ALMEIDA, A.M. et al. (Orgs.) Pensando a Família no Brasil. Rio de Janeiro, Espaço e Tempo/UFRRJ, 1987, p.53-66.

ALMEIDA, M. A. G. Famílias, cuidados e deficiências: um estudo a partir de famílias de camadas médias de Porto Alegre. Dissertação (Mestrado) - Pontifícia Universidade Católica do Rio Grande do Sul, Porto Alegre, 2011.

ALVAREZ, A. P. E; CARVALHO, M. C. Novas estratégias no campo da inclusão social: moradia assistida e trabalho assistido. Psicologia para América Latina. n.8, México, nov. 2006.

ANAUATE, C.; AMIRALIAN, M. L. T. M. A importância da intervenção precoce com pais de bebês que nascem com alguma deficiência. Educar, Curitiba, n. 30, p. 197-210, 2007.

ARAUJO, C; SCALON, C. Percepções e atitudes de mulheres e homens sobre a conciliação entre família e trabalho pago no Brasil. In: ARAUJO, C; SCALON, C. (Orgs.). Gênero, Família e Trabalho no Brasil, Rio de Janeiro: FGV/FAPERJ, p. 15-78, 2003.

ARIÈS, P. História Social da Criança e da Família. Rio de Janeiro: Editora Guanabara, 1978.

ARRIAGADA, I. Transformações sociais e demográficas das famílias latinoamericanas. In: DOMINGUES, J. M.; MANEIRO, M. (Org.). América Latina Hoje: conceitos e interpretações, Rio de Janeiro, Civilização Brasileira, 2006, p. 197-223. 
BARBOSA et al. Cuidado da criança com deficiência: suporte social acessado pelas mães. Rev. Gaúcha Enferm, v. 30, n. 3, Porto Alegre, p. 406-412, set. 2009.

BASTOS, O. M.; DESLANDES, S. F. A experiência de ter um filho com deficiência mental: narrativas de mães. Cadernos de Saúde Pública, v. 24, n.9, Rio de Janeiro, p. 2141-2150, set. 2008.

BECKER, H. S. Métodos de Pesquisa em Ciências Sociais. São Paulo: HUCITEC, 1994.

BERQUÓ, E. A família no século XXI: um enfoque demográfico. Rev. Bras. Est. Pop., São Paulo, v. 6, n. 2, p.1-16, 1989.

BILAC, E. D. Sobre as transformações nas estruturas familiares no Brasil. Notas muito preliminares. In: RIBEIRO, I.; RIBEIRO, A. C. T. (Orgs.). Famílias em Processos Contemporâneos: inovações culturais na sociedade brasileira, São Paulo, Edições Loyola, p. 43-61, 1995.

BOFF, L. Saber Cuidar: ética do humano - compaixão pela terra. Rio de Janeiro: Vozes, 2011.

BRASIL. Política Nacional de Assistência Social, Brasília, Ministério do Desenvolvimento Social e Combate à Fome/ Conselho Nacional de Assistência Social, 2004.

Lei Orgânica da Assistência Social, Brasília, Ministério do Desenvolvimento Social e Combate à Fome, 1993.

Resolução no 196, de 10 de outubro de 1996, aprova diretrizes e normas regulamentadoras de pesquisas envolvendo seres humanos, Brasília, Ministério da Saúde, Conselho Nacional de Saúde, 1996. 
BRASIL. Decreto $\mathbf{n}^{0}$ 3.298, de 20 de dezembro de 1999. Regulamenta a Lei $\mathrm{n}^{\mathrm{o}}$ 7.853, de 24 de outubro de 1989, dispõe sobre a Política Nacional para a Integração da Pessoa Portadora de Deficiência, consolida as normas de proteção, e dá outras providências. Disponível em: < http://www81.dataprev.gov.br/sislex/paginas/23/1999/3298.htm> Acesso em: 7 abr. 2012.

BRONFENBRENNER, U. Ecologia do Desenvolvimento Humano. Porto Alegre, Artes Médicas, 1996.

BRUSCHINI, C. Teoria crítica da família. In: AZEVEDO. M. A.; GUERRA, V. N. (Orgs.). Infância e violência doméstica: fronteiras do conhecimento. São Paulo: Cortez, 1993.

CARDOSO, L.; GALERA, S. A. F. O cuidado em saúde mental na atualidade. Ver. Esc. Enferm. USP, v. 45, n. 3, São Paulo, p. 687-691, 2011.

CARVALHO, M. C. B. O lugar da família na política social. In: CARVALHO, M. C. B. (Org.). A Família Contemporânea em Debate. 5 ed. São Paulo: Cortez, p. 13-27, 2003.

CARVALHO, M. I. L. B de. Entre os cuidados e os cuidadores: o feminino na configuração da política de cuidados às pessoas idosas. Campus Social, n. 3, 2007.

CARVALHO et al. Mulheres e cuidado: bases psicobiológicas ou arbitrariedade cultural? Paidéia, v.18, n. 41, p. 431-444, 2008.

CASTELLS, M, O fim do patriarcalismo: movimentos sociais, família e sexualidade na era da informação. In: CASTELLS, M. O Poder da Identidade. v. 2, São Paulo: Paz e Terra, 2000.

CAVAlCANTE, F. G. Pessoas Muito Especiais: a construção social do portador de deficiência e a reinvenção da família. Rio de Janeiro: Fiocruz, 2003. 
CAVAlCANTE, F. G. A família em discussão. In: CONGRESSO INES: 150 anos no cenário da educação brasileira. 2007, Rio de Janeiro. Anais... Rio de Janeiro: INES - Divisão de Estudos e Pesquisas, p. 177-183, 2007.

CENTRO DE ESTUdOS DO GENOMA HUMANO. Síndrome de Rett. Disponível em: < http://genoma.ib.usp.br> Acesso em 30/03/2013.

COSTA, R. G. Reprodução e gênero: paternidades, masculinidades e teorias da concepção. Revista Estudos Feministas, Florianópolis, v. 10, n.2, p. 339-355, 2002.

DINIZ, D.; SQUINCA, F.; MEDEIROS, M. Deficiência, cuidado e justiça distributiva. SérieAnis, n. 48, Brasília, p.1-6, mai. 2007.

DURHAM, E. Família e Reprodução Humana. In: Perspectivas Antropológicas da Mulher, Rio de Janeiro: Zahar, p. 15-44, 1983.

ELSEN et al. O Cuidado profissional às famílias que vivenciam a doença crônica em seu cotidiano. Cienc. Cuid. Saúde, 8 supl. p. 11-22, 2009.

FERrAZ, M. S. F. C. O conceito de saúde. Revista de Saúde Pública, v.31, n.5, São Paulo, out. 1997.

FLICK, U. Introdução à Pesquisa Qualitativa, Porto Alegre, Artes Médicas, 2009.

FOUCAULT, M. Os anormais. São Paulo: WMF Martins Fontes, 2010a.

Vigiar e Punir. História da Violência nas Prisões. 38 a edição. Petrópolis: Editora Vozes, 2010b.

Resumo dos cursos de Collège de France (1970- 1982). Rio de Janeiro: ZAHAR, 1997. 
FUndAÇÃo Getúlio VARGAS. A Nova Classe Média. Disponível em: <http:// http://www.fgv.br/cps/classe media/> Acesso em: 9 mai. 2012.

GIFFIN, K. Pobreza, desigualdade e equidade em saúde: considerações a partir de uma perspectiva de gênero transversal. Cadernos de Saúde Pública, Rio de Janeiro, v.18, 2002.

GIFFIN, K; CAVALCANTI, C. Homens e reprodução. Disponível em <http://www.ieg.ufsc.br> Acesso em 01 dez. 2012.

GIULANI, P. C. Os movimentos de trabalhadoras e a sociedade brasileira. In: História das mulheres no Brasil. São Paulo: Contexto, p. 641-672, 2006.

GÓES, F. A. B. Os Pais e Seu Filho Portador de Necessidades Especiais/ Deficiência Mental: um encontro inesperado. Dissertação (Mestrado) Universidade Católica de Pernambuco, Recife, 2004. Um encontro inesperado: os pais e seu filho com deficiência mental. Psicologia, ciência e profissão, v.26, n. 3, p. 450-461, 2006.

GOFFMAN, E. Estigma: notas sobre a manipulação da identidade deteriorada. Rio de Janeiro: LTC, 2008.

GOMES, R. As questões de gênero e o exercício da paternidade. In: Exercício da paternidade. Porto Alegre: Artes Médicas, p. 175-182, 1998.

GONÇALVES, M. A. Expostos, roda e mulheres: a lógica da ambigüidade médico-higienista. In: ALMEIDA, A. (Org.). Pensando a família no Brasil: da colônia à modernidade. Rio de Janeiro: Espaço e Tempo, 1987.

HEILBORN, M. L. Construção de si, gênero e sexualidade. In: Sexualidade: o olhar das Ciências Sociais. Rio de Janeiro: Jorge Zahar Ed., p. 40-58, 1999. 
HONORA, M.; FRIZANCO, M. L. Esclarecendo as Deficiências: aspectos teóricos e práticos para contribuir com uma sociedade inclusiva. São Paulo: Ciranda Cultural Editora e Distribuidora Ltda., 2008. 192p.

INSTITUTO NEUROLÓGICO DE SÃO PAULO. Lesões Cerebrais Associadas à Epilepsia. Disponível em: < http://www.institutoneurologico.com.br/home/lesoescerebrais.shtml> Acesso em 01/04/2013.

JUNIOR, A. P. Um país que mascara o seu rosto. In: JUNIOR, A. P; BEZERRA, J. L.; HERINGER, R. (Orgs). Os impasses da cidadania. Rio de Janeiro: Ed. Graphos, p. 13-35, 1992.

LOBATO, D. Siblings of handicapped children: a review. Journal of Autism and Developmental Disorders, v. 13, n.4, p. 347-364, 1983.

LYRA, J. Paternidade adolescente: uma proposta de intervenção. Dissertação (Mestrado) - Psicologia Social. Pontifícia Universidade Católica de São Paulo. Disponível em <http:// www.papai.org.br> Acesso em 14 de junho de 2010.

LUZ, P. M.; MIRANDA, K. C. L. As bases filosóficas e históricas do cuidado e a convocação de parceiros sexuais em HIV/AIDS como forma de cuidar. Ciênc. Saúde Coletiva, v.15, supl.1, Rio de Janeiro, Jun. 2010.

MACEDO, D. R. S; ROSA, S. D. A moradia assistida e o papel da pessoa portadora de deficiência no âmbito familiar. REU, v. 36, n. 2, Sorocaba, São Paulo, p. 49-57, set. 2010.

MACHADO, C. A. M.; SCRAMIN, A. P. Enfermeiros com deficiência física adquirida: reflexões sobre o cuidado e o cuidar em enfermagem. Ciência, Cuidado e Saúde, v. 1, n.2, Maringá, p. 321-328, jul./dez. 2002. 
MAIA, R. F. C.; GUEDES, A. L.; RAMOS, C. F.P. A Concepção de Família. In: CONGRESSO INES: 150 anos no Cenário da Educação Brasileira. Rio de Janeiro: Instituto Nacional de Educação de Surdos, p. 177-186, 2007.

MARTINES, W. R. V.; MACHADO, A. L. Produções de cuidado e subjetividade. Revista Brasileira de Enfermagem, v. 62, n.2, Brasília, p. 328-333, mar./abr. 2010.

MINAYO, M. C. S. (Org.). Pesquisa Social: teoria, método e criatividade. Petrópolis: Vozes, 2003.

MINISTÉRIO DA SAÚDE. Portal da Saúde. Disponível em: $<\mathrm{http}$ ///portalsaude.saude.gov.br/portalsaude/index.cfm> Acesso em: 02 fevereiro 2012.

MINUCHIN, S. Famílias: Funcionamento e tratamento, Porto Alegre, Artes Médicas, 1982.

MIOTO, R. C. T. Novas propostas e velhos princípios: a assistência às famílias no contexto de programas de orientação e apoio sociofamiliar. In: SALES, M. A.; MATOS, M. C. de; LEAL, M. C. (Orgs.). Política social, família e juventude: uma questão de direitos. São Paulo: Cortez, p. 43-59, 2006.

Família e saúde mental: contribuições para reflexão sobre processos familiares. Revista Katálysis, Florianópolis, n.2, p. 20-26, mai. 1998.

MORGADO, R. Família (s) e Relações de Gênero. In: Praia Vermelha: estudos de política e teoria social. Rio de Janeiro: UFRJ, p. 190-213, 2001.

NEVES, T. R. L. Movimentos sociais e cidadania: quando a pessoa com deficiência mental fala na primeira pessoa do singular. Disponível em: <http://www.apalminas.org.br> Acesso em 10 jun. 2011.

NOLASCO, S. O Mito da Masculinidade. Rio de Janeiro: Rocco, 1993. 


\section{OLIVEIRA. A. C. Abuso Sexual Intrafamiliar de Crianças e Ruptura do}

Segredo: consequiências para as famílias. 233f. Tese (Doutorado) - Departamento de Serviço Social. Pontifícia Universidade Católica do Rio de Janeiro, Rio de Janeiro, 2011.

OLIVEIRA. A. C.; AMERICANO, N. S. A Teoria Winnicottiana. In: OLIVEIRA. A. C.; AMERICANO, N. S. Crianças e Adolescentes em Situação de Rua: A Difícil Arte de Cuidar. Rio de Janeiro: Nova Pesquisa, p. 21-34, 2005.

OLIVEIRA, L. C. Visibilidade e Participação Política: Um estudo no Conselho Municipal da Pessoa com Deficiência em Niterói. 178f. Dissertação (Mestrado) Departamento de Serviço Social. Pontifícia Universidade Católica do Rio de Janeiro, Rio de Janeiro, 2010.

ORTIZ et al. Mudanças no contexto do cuidado: desafios para a enfermagem. Rev. Latino-Am. Enfermagem, Ribeirão Preto, p. 1-9, jul./ago. 2011.

PEREIRA, A. A. P. Mudanças estruturais, política social e papel da família: Crítica ao pluralismo de bem-estar. In: SALES, M. A.; MATOS, M. C. de; LEAL, M. C. (Org.). Política social, família e juventude: uma questão de direitos. São Paulo: Cortez, p. 25-42, 2006.

PETEAN, E. B. L.; NETO, J. M. P. Investigações em aconselhamento genético: impacto da primeira notícia - A reação dos pais à deficiência. Medicina, n.31, Ribeirão Preto, p.288-295, abr./jun. 1998.

PETEAN, E. B. L. P.; MURATA, M. F. Paralisia cerebral: conhecimento das mães sobre o diagnóstico e o impacto deste na dinâmica familiar. Paidéia. Ribeirão Preto, p. 40-46, ago./dez. 2000.

PSIQUEWEB. Transtorno Desintegrativo da Infância. Disponível em: $<$ http://www.psiqweb.med.br $>$. Acesso em 01/04/2013. 
QUINTANEIRO, T. Retratos de mulher: o cotidiano feminino no Brasil sob o olhar de viageiros do século XIX, Petrópolis: Vozes, 1995.

RIDENTI, S.G.V. A desigualdade de gênero nas relações parentais: o exemplo das custódias dos filhos. In: Arilha M, Ridenti S G V, Medrado B (Org.). Homens e masculinidades: outras palavras. São Paulo: ECOS, 1998.

RIBEIRO, C. R. O mito do cuidado. Rev. Latino-Am. Enfermagem, Ribeirão Preto, v. 9, n. 1, p. 123-124, jan. 2001.

RIZZINI, I. Do confinamento ao acolhimento - Institucionalização de crianças e adolescentes com deficiência: desafios e caminhos. Disponível em 〈http://www.ciespi.org.br/portugues/downloads/resultados_confinamento.pdf $>$ Acesso em 01/05/2010.

RIZZINI, I.; MENEZES, C. D. Crianças e Adolescentes com Deficiência Mental no Brasil: um panorama da literatura e dos dados demográficos. 1.ed. Rio de Janeiro: CIESPI, 2010.

RIZZINI et al. Percepções e experiências de participação cidadã de crianças e adolescentes no Rio de Janeiro. Rev. Katál. Florianópolis, v. 10, n.2, p. 164-177, jul./dez, 2007.

ROCHA, F. M.; CARVALHO, C. R. L. Relato de caso de paciente do gênero masculino portador das Síndromes de Freman-Sheldon e Schwartz-Lampel. Revista Ceciliana. v. 3, n.1, p. 62-64, jun. 2011.

SANTOS, A. C. C. F dos. Referencial de cuidar em Enfermagem Psiquiátrica: um processo de reflexão de um grupo de enfermeiras. Esc. Anna Nery Rev. Enferm, Rio de Janeiro, v. 13, n. 1, p. 51-55, jan./mar. 2009. 
SANTOS, S. M. A.; RIFIOTS, T. Cuidadores familiares de idosos dementados um estudo crítico de práticas quotidianas e políticas sociais de judicialização e reprivatização. In: GROSSI, M. P. e SCHWADE, E. Política e Cotidiano: estudos antropológicos sobre gênero, família e sexualidade, Florianópolis, Nova Letra, 2006, p. 95-114.

SARAIVA, E. S. Paternidade e masculinidade: tradição, herança e reinvenção Dissertação (Mestrado) - Fiocruz, Porto Alegre, 1998.

SILVA, A. Cuidado Transdimensional: um paradigma emergente. Pelotas: Ed. Universitária. Florianópolis: Programa de Pós-Graduação em Enfermagem UFSC, 1997.

SILVA, N. C. B. Contexto Familiar de Crianças com Síndrome de Down: interação e envolvimento paterno e materno. 2007. 169f. Dissertação (Mestrado) Universidade Federal de São Carlos, São Paulo, 2007.

SILVA, N. L. P. Crianças Pré-escolares com Síndrome de Down e suas Interações Familiares. 129f. Dissertação (Mestrado) - Universidade de Brasília, Brasília, 2000.

SILVA, N. L. P.; DESSEN, M. A. Deficiência mental e família: implicações para o desenvolvimento da criança. Psicologia: teoria e pesquisa, v. 17, n.2, Brasília, p.133-141, mai/ago. 2001.

SILVA, R. G. Gênero, Cuidado e Deficiência: um estudo no Ministério Público do Distrito Federal e Territórios. 2008. Monografia (Graduação - Universidade de Brasília, Brasília, 2008.

SILVA et al. O cuidado na perspectiva de Leonardo Boff, uma personalidade a ser (re)descoberta na enfermagem. Revista Brasileira de Enfermagem, v. 58, n. 4, p.471-475, jul./ago. 2005. 
SIMEONSSON, R. J.; McHALE, S. M. Review: Research on handicapped children: sibling relationships. Child: care, health and development, n.7, p. 153$171,1981$.

SOARES, M. P. G. Comportamento de cuidado: quando crianças com necessidades especiais são cuidadas por irmãos em ambiente familiar. Dissertação (Mestrado) - Universidade Católica do Salvador, Salvador, 2005.

SORJ, B. Percepções sobre esferas separadas de gênero. In: ARAUJO, C; SCALON, C. (Orgs.). Gênero, Família e Trabalho no Brasil, Rio de Janeiro: FGV/FAPERJ, p. 79-88, 2003.

SOUTO, K. C. A Presença da Paternidade no Processo de Formação dos Filhos. 99f. Monografia (Graduação) - Escola de Serviço Social. Universidade Federal do Rio de Janeiro, Rio de Janeiro, 2005.

SOUZA, L. G. A. Cuidando do Filho com Deficiência Mental: desvelamentos de vivências de pais no seu ser-com-o-filho. 122f. Dissertação (Mestrado) Universidade de São Paulo, Ribeirão Preto, 2003.

SPROVIERI, M. H. S.; JUNIOR, F. B. A. Dinâmica familiar de crianças autistas. Arq. Neuropsiquiatr., n. 59, p.230-237, 2001.

STAMM, M. Evolução do cuidado na enfermagem até o cuidado transdimensional: uma revisão de literatura. Ciência, Cuidado e Saúde, Maringá, v. 1, n. 2, p. 293-298, jul./dez. 2002.

STAMM, M; MIOTO, M. Família e cuidado: uma leitura para além do óbvio. Ciência, cuidado e saúde. Maringá, v. 2, n.2, p. 161-168, juj./dez. 2003.

SZYMANSKY, H. A Prática de pesquisa participante junto a famílias de baixa renda: o jogo cotidiano do vivido e do pensado. Disponível em < http://www.ifocien.org > Acesso em 01 dez. 2012. 
SZYMANSKY, H. Teorias e "teorias" de famílias. In: CARVALHO et al. A família contemporânea em debate. São Paulo: Record, p. 23-27, 2005.

TRATADO DE FONOAUDIOLOGIA OTACÍLIO LOPES FILHO. Disacusia. Disponível em: < http://www.ebah.com.br> Acesso em: 01 abr. 2013.

TRONTO, J. C. Mulheres e cuidados: o que as feministas podem aprender sobre a moralidade a partir disso? In: JAGGAR, A; BORDO, S. [eds]. Gênero, corpo, conhecimento. Rio de Janeiro: Record, Rosa dos Tempos, p. 186-203, 1997.

WETZEL et al. A inserção da família no cuidado de um centro de atenção psicossocial. Ciência, Cuidado e Saúde, 2009. 


\title{
6 \\ Apêndice
}

\section{1}

\section{Termo de Consentimento Livre e Esclarecido}

Pontifícia Universidade Católica

DO RIO DE JANEIRO

\author{
TERMO DE CONSENTIMENTO LIVRE E ESCLARECIDO
}

O Sr. / A Sra.

Pai/ mãe de

Está sendo convidado(a) para participar da pesquisa intitulada "A Constatação da Deficiência do(a) Filho(a) e os Processos de (Re)Organização das Famílias para o Cuidado", que tem como objetivo conhecer os processos de (re)organização das famílias a partir da constatação da deficiência do(a) filho(a), em particular no que se refere ao cuidado da prole.

Suas respostas serão tratadas de forma autônoma e confidencial, isto é, em nenhum momento será divulgado o seu nome ou do(a) seu(sua) filho(a) em qualquer fase da pesquisa.

A sua participação é voluntária, portanto você pode desistir de participar em qualquer momento, por qualquer razão, bastando para tal comunicar sua desistência, sem que haja qualquer consequência para você ou para o(a) seu(sua) filho(a), agora ou no futuro.

Sua participação nesta pesquisa consistirá em narrar a história da sua família, contando-nos como ela organizou-se a partir da constatação da deficiência 
do(a) seu (sua) filho(a), sobretudo em relação ao cuidado com ele(a). Deixaremos você falar livremente, mas poderemos pedir que aprofunde alguma narração e, no fim, poderemos fazer outras perguntas, todas relacionadas ao objetivo de conhecer os processos de (re)organização da sua família, a partir da constatação da deficiência do(a) seu(sua) filho(a).

É fundamental que a narração e as respostas sejam fiéis à realidade, para que a pesquisa tenha consistência científica. Ressaltamos que o nosso conhecimento da história da sua família não resultará em qualquer tipo de punição ou constrangimento para você ou para seu(sua) filho(a) com relação ao benefício de saúde da empresa.

A entrevista será gravada para melhorarmos a qualidade dos dados. Entretanto, esta poderá ser interrompida e a gravação descartada a qualquer momento, se assim você desejar. Com exceção do seu nome, todos os dados da entrevista serão transcritos. Em atendimento às normas regulamentares de pesquisas envolvendo seres humanos, a transcrição será mantida em arquivo, sob minha guarda, por cinco anos. (BRASIL, 1996).

Você receberá uma cópia deste documento, onde consta o telefone da pesquisadora e do seu orientador, para que você possa dirimir dúvidas sobre o projeto e sua participação, agora ou a qualquer momento.

Declaro compreender as informações e compromissos expressos neste TERMO DE CONSENTIMENTO e estou de acordo em participar da pesquisa proposta.

Assinatura do participante:

Assinatura da pesquisadora:

Local:

Data: 
Telefone da mestranda do curso de Serviço Social da Pontifícia Universidade Católica do Rio de Janeiro Keila Cabral Souto: 2144-7316.

Endereço Eletrônico: Keilacsouto1@yahoo.com.br

Telefone do orientador prof. Doutor da Pontifícia Universidade Católica do Rio de Janeiro Antonio Carlos de Oliveira: 3527-1290 (ramal 212).

Endereço Eletrônico: antoniocarlos@ puc-rio.br 


\title{
7 \\ Anexos
}

\section{1 \\ Anexo 1 - Autorização da Câmara de Ética para Realização da Pesquisa de Campo}

\author{
Pontificia Universidade Católica $_{\text {a }}$ \\ DO RIO DE JANEIRO
}

Pontificia Universidade Catolica do Rio de Janeiro

Cämara de Ética em Pesquisa da PUC - Rio

\section{PARECER DA COMISSÃO DE ÉTICA EM PESQUISA DA PUC-RIO (2012-27)}

A Comissāo de Ética em Pesquisa da PUC-Plio foi constituida como uma Cămara ospecifica do Conselho de Ensino e Pesquisa conforme decisão deste orgáo colegiado com atribuiç̧ăo de avallar projetos de pesquisa do ponto de vista de suas implicaçōes éticas.

\section{Identificaçâo:}

Título: Constataçăo da deficiencia de um filho e processos de mudanças nas familias (Departamento de Serviço Social da PUC-Plio)

Autora: Keila Cabral Souto (Mestranda do Departamento de Serviço Social da PUC-Rio)

Orientador: Antonio Carlos de Olivelra (Professor do Departamento de Serviço Social da PUC-Rio)

Apresentação: Trata-se de um estudo qualitativo que visa conhecer o processo de mudanças que ocorrem nas familias após a constataçāo da deficiència de um filho, no que se refere ao cuidado, à composiçâo e aos padröes de consumo familiar. Propöe entrevistar preferencialmente duas mulheres (mäes) e dois homens (pais) integrantes de familias distintas, selecionadas a partir de sua inserçāo num programa de assistência a pessoas com deficiência.

Aspectos éticos: O projeto $\theta$ o Termo de Consentimento Livre e Esclarecido - TCLE, nele anexado, estăo de acordo com os principios e valores da Universidade conforme previstos em seu Marco Referencial, Estatuto o Regimento no que se refere as responsabilidades de seu corpo docente e discente.

E necessário anexar à dissertação, resultante do trabalho de pesquisa, a autorizaçâo da instituiçăo para a realizaçăo do estudo proposto.

Parecer: Considerando os elementos expostos somos de parecer tavorảvel à aprovaçă̄o do projeto quanto aos principios e critérios estabelecidos pela Comissăo de Ética em Pesquisa da PUC-Rio.

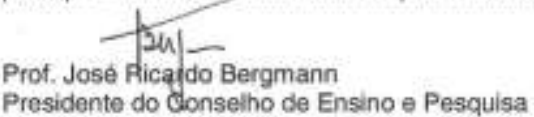

Pio de Janeiro, 20 de agosto de 2012 